UNITED STATES DEPARTMENT OF THE INTERIOR

J. A. Krug, Secretary

FISH AND WILDLIFE SERVICE

Albert M. Day, Director

North American Fauna 58

\title{
HABITS, FOOD, AND ECONOMIC STATUS OF THE BAND-TAILED PIGEON
}

BY

JOHNSON A. NEFF

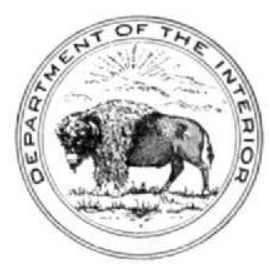

UNITED STATES

GOVERNMENT PRINTING OFFICE

WASHINGTON : 1947

For sale by the Superintendent of Documents, U. S. Government Printing Ofice Washington 25, D. C.-Price 20 cents 


\section{CONTENTS}

\begin{tabular}{|c|c|c|c|}
\hline & & & \\
\hline troduction $\ldots \ldots \ldots \ldots \ldots \ldots$ & 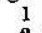 & Value as a game bird $\ldots \ldots \ldots \ldots \ldots \ldots$ & \\
\hline istory of knowledge of the species.... & & Present status $\ldots \ldots \ldots \ldots \ldots \ldots \ldots$ & \\
\hline atural history $\ldots \ldots \ldots \ldots \ldots \ldots \ldots \ldots$. & 4 & Management possibilities ....... & \\
\hline Description $\quad \ldots \ldots \ldots \ldots \ldots \ldots \ldots \ldots$ & & gricultural relationships & \\
\hline$\ldots \ldots \ldots \ldots \ldots \ldots \ldots \ldots \ldots \ldots$, & 1 & Depredations & \\
\hline Plumages $\quad \ldots \ldots \ldots \ldots \ldots \ldots \ldots$ & & Cherries, grapes, and prunes.... & \\
\hline Courtship $\quad \ldots \ldots \ldots \ldots \ldots \ldots \ldots \ldots$ & 5 & Grain crops $\ldots \ldots \ldots \ldots \ldots \ldots \ldots$ & \\
\hline 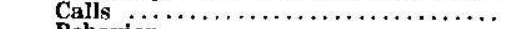 & & ..... & \\
\hline$\ldots$ & & f crop protection. & \\
\hline & & Food $\mathrm{h}$ & \\
\hline ng & & & \\
\hline loce & & & \\
\hline munal nature in ne & & nations. . & \\
\hline ......... & & rences........... & \\
\hline ati & 1. & & \\
\hline & 1 & ... & \\
\hline 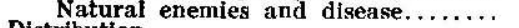 & 17 & er & \\
\hline & & & \\
\hline .. & & ... & \\
\hline & 1 & el. & \\
\hline & & ... & \\
\hline & 2 & ... & \\
\hline & & & \\
\hline & & & \\
\hline & & & \\
\hline
\end{tabular}




\section{HABITS, FOOD, AND ECONOMIC STATUS OF THE BAND-TAILED PIGEON}

By Johnson A. NerF, Biologist, Economic Investigations. Division of Wildlife Research, Fish and Wildife Service

\section{INTRODUCTION}

For many years the band-tailed pigeon (Columba fasciata fasciata) has pleasurably interested sportsmen and ornithologists of the western United States, but at times it has aroused the ire of agriculturalists. Pursued as a game bird in some parts of its range for more than 70 years (except for a period of complete protection from 1913 to 1932 ), the band-tailed pigeon has, through its wariness and powers of flight, survived in sufficient numbers to be treated as a game species in a few far-scattered localities.

Bandtails, blue pigeons, blue rocks, or wild pigeons, as they are called in different parts of their range, are discussed in many pages of the ornithological literature of the past 75 years, yet information is still inadequate for determination of the exact status of the species and for definition of practical methods for its management.

Food and cover are the primary essentials for the welfare of any species. In few instances, however, does the availability of an ample food supply influence the habits, range, and distribution of a species as extensively as it does those of the band-tailed pigeon. This report summarizes, for practical use, the available information on the range, life history, habits, food, and game status of this bird, and records the findings from the examination of 691 stomachs and crops.

Prior to 1937 the Food Habits Laboratory, of the Bureau of Biological Survey (now part of the Fish and Wildlife Service), had accumulated 142 stomachs and gullets of the band-tailed pigeon, and 30 of these had been examined by Sterling Bunnell, E. R. Kalmbach, and Alexander Wetmore. Early in 1937 continuation of this study was assigned to the writer. The remaining 62 stomachs and crops were examined, 549 additional crops and/or stomachs were acquired and examined, and field observations were carried on in 5 States.

NotE.-Grateful acknowledgment of services rendered and of interest shown in this study of the banci-tailed pigeon is made to a group of cooperators too numerous to mention individually. Thirty former and present employees of the Fish and Wildlife Service have assisted by collecting specinens, analyzing crop and stomach contents, identifying food items, supplying information in official reports or by letter, and assisting in the writing. revising, and editing of this report. Valued assistance has been given also by various employees of the Forest Service and the Soil Conservation Service of the United States Department of Agriculture, and of the office of Indian Affairs and the National Park Service of the United States Department of the Interior. Most of the western State Game Departments, and many of their wardens individually, have cooperated in collecting specimens and in furnishing information. Certain scientific institutions, among them the Colorado Museum of Natural History, the California Academy of Sciences, and the Museum of Northern Arizona, and biologists of many of the universities within the range of the bancitail, as well as many bird students, have also contributed freely. 


\section{HISTORY OF KNOWLEDGE OF THE SPECIES}

The type specimen of the band-tailed pigeon was obtained on Plum Creek, near Castle Rock, Douglas County, Colo., by members of Long's expedition to the Rocky Mountains, and described for the first time by Say in 1823. Eggs were first collected by Lieutenant Benson (Bendire 1892) ${ }^{1}$ near Fort Huachuca, Ariz., on September 25, 1885.

It is impracticable, if not impossible, to compare the present numbers of the pigeons with those of any year in the early history of the West. The variation in degree of concentration in response to changing food supplies and the widespread wilderness range of the species make it difficult now to draw satisfactory conclusions from the scattered reports on abundance.

Prior to 1913 small notice had been taken of the species as game in most States and little protection was afforded it. In the Northwest most of the shooting was done during the spring months when the pigeons were concentrated in grainfields. In California, however, pigeon hunting, including market shooting, was developed to a high degree. During the period before the automobile became a great factor in hunter transportation, gunning had occurred locally wherever pigeons concentrated. Although the number of hunters increased annually as the West became more densely settled, lack of transportation limited the hunters to relatively small areas. Ornithologists were few in number and widely scattered, hence there is no estimate of early-day pigeon abundance that would make possible comparison with present numbers. Early writers use such terms as "quite numerous," "common but never abundant," "very abundant," "common," "occasionally quite plentiful," and "fairly abundant."

Only one instance has been noted that specified truly great numbers. Bendire (1892) quotes Carpenter as follows: “. . this species is most numerous near the mouth of the Columbia River, where immense flocks were to be seen from May to October 1865, which fairly rivaled those of the Passenger Pigeon."

During the winter of 1911-12 there was an enormous flight of band-tailed pigeons along the California coast from Paso Robles to Nordhoff, and sport and market hunting flourished. Chambers (1912) described conditions in that area, stating that one market hunter shipped some 2,000 pigeons to city hotels, that the morning train from San Luis Obispo to Los Olivos carried about 100 hunters each Sunday morning, and that frequently the hunters took an average of 30 birds each. The number of pigeons killed in the large area covered by that winter concentration must have been enormous, for hunters came from long distances. Apparently the birds remained in the area until shot out. This unusual congregation of birds and of hunters brought the dangers of the bandtail's situation to public notice, and in 1913 Grinnell in furthering the drive for protection published an excellent summary of the status of the species.

As practically the entire band-tailed pigeon population of the

Publications referred to parenthetically by date are listed in the Bibllography, p. 71 . 
West Coast wintered in a relatively small area in central and southern California, it was possible for concentrated shooting to decimate the numbers of the species. The instance described by Chambers aroused ornithologists to the great need of the birds for protection.

The first action came in 1913 when in the appropriation act for the United States Department of Agriculture there was embodied what was commonly known as the Migratory Bird Law of 1913. This act asserted the authority of the United States Government over those birds, both game and nongame, that in the course of their northern and southern migrations passed through any of the States or that did not remain permanently within the borders of any State or Territory. Under this legislation the Department of Agriculture was directed to adopt suitable regulations to give effect to the act, and when the regulations were approved and proclaimed by the President on October 1, 1913, they embodied a closed season on certain species, including the band-tailed pigeon, until September 1, 1918.

This act served its purpose though there was doubt that it could stand the test of constitutionality. Therefore the treaty with Great Britain for the protection of birds migrating between the United States and Canada was negotiated and was made effective by the adoption of the Migratory Bird Treaty Act, of July 3, 1918. Under this unquestionably constitutional act the closed seasons on certain species prescribed in 1913 were continued, and the bandtailed pigeon was afforded complete protection until 1932, during which period the birds gained slowly but consistently in numbers.

Owing to the growing numbers of complaints by farmers in California that pigeons were seriously damaging their cherries, the Secretary of Agriculture, pursuant to authority granted in the Migratory Bird Treaty Act, issued an order on April 30, 1924, allowing the granting of permits for the destruction of band-tailed pigeons that were attacking cherry crops in that State. In June 1930 an amended order extended the same privilege to Arizona and Washington. Permits were issuable covering the period from May 15 to July 31, and the grounds for giving them included damage to cherries and other small fruits. It was provided also that the birds killed in protecting crops could be used as food by the landowner or lessee. Complaints of alleged depredations on agricultural products continued to increase, and the demand for permits grew until it was apparent that soon in some sections they would in effect create almost an open season and that during the breeding season of the birds.

The pigeons continued to increase slowly but steadily in numbers, and in 1932 an open shooting season was permitted in Arizona, California, New Mexico, Oregon, and Washington. In Colorado no open season was permitted until 1944, and that only in 12 southwesterly counties. In Texas and Utah the birds are so sparsely distributed that no open shooting has been permitted. The open season in each State in which band-tailed pigeons are present in shootable numbers was limited to 15 days annually until 1942, 
when the period was extended to 30 days ; the possession bag limit in all localities has remained at 10 birds.

\section{NATURAL HISTORY}

\section{DESCRIPTION}

The band-tailed pigeon is described by Grinnell, Bryant, and Storer (1918) as follows:

Adults, both sexes,- - Head pinkish brown or vinaceous (exact tint varying greatly among different individuals), darkest and more purpiish on top and back of head, more ashy on chin and cheeks; base of bill straw yellow, and black; naked eyelids, coral red; narrow collar around hind neck, white, averaging more conspicuous in males; broad area on sides and back of neck (below white collar), iridescent bronzy green; back, dark olive brown; rump and bases of tail feathers, dark bluish gray; ill-defined band across middle of tail, dull black; terminal portions of tail feathers, drab, lightest on outer ones; outer surface of closed wing, chiefly light gray, the coverts narrowly margined with white; flight feathers, brownish black; lining of wing and axillars, gray; under surface of flight feathers, duil brown; under surface of body, pinkish brown or vinaceous, deepest on breast and sides, paling to almost white on belly; under tail coverts, white; under surface of terminal portion of tail, whitish, distinctly lighter than upper surface of same; feet straw yellow. In some females the tone of coloration verges towards grayish rather than pinkish brown. Juvenile plumage.-Similar to that of adult, but vinaceous tinge wholly lacking; neck without white collar or iridescent bronzing; under surface dark brownish, with feather tippings of lighter color, giving a faintly scaled effect.

Marks for field identification.-Largest of our wild pigeons (about the bulk of a domestic pigeon); general bluish coloration; distinct dark band across middle of square-ended tail; wings without white patches.

\section{SIZE}

Of 320 band-tailed pigeons examined by John C. Knox near Mountain Park, N. Mex., in June 1941, the heaviest adult weighed $151 / 2$ ounces, the smallest $8 \% / 4$ cunces. D. M. Gorsuch, of the United States Forest Service, weighed 6 birds collected at Williams, Ariz., between September 26 and November 8, 1941. Two adults weighed, respectively, 345 and 359 grams (or 12.16 and 12.31 ounces), and four young, respectively, 270, 270, 290, and 290 grams (or 9.52 and 10.23 ounces). United States Game Management Agent Frank F. Poley and the writer examined 22 bandtails shot in Colorado between September 17 and 19, 1945; the average weight of 17 adults was 338 grams (or 11.2 ounces), the largest bird weighing 372 grams (or 13.1 ounces), the smallest 292 grams (or 10.3 ounces), and the average weight of 5 young was 270 grams (or 9.52 ounces). A 17-day-old nestling in Colorado weighed 140 grams (or 4.9 ounces).

Ridgway (1916) gives the following measurements for the band-tailed pigeon as taken from skins, the figures representing in millimeters respectively the smallest and the largest measurements of the birds he examined, and, in parentheses, the average $(25.4 \mathrm{~mm} .=1 \mathrm{inch})$ :

Adult males, 38 specimens.-Length, 342-400 (363); wing, 195-221 (208.6); tril, 122-151. (139.4); culmen, 16-20 (18); tarsus, 24.5-29.5 (27); middle toe. $27.5-34(30.4)$. 
Adult females, 28 specimens.--Length, 334-395 (338); wing, 193-218 (204) ; tail, 121-149 (134.1) ; culmen, 15.5-19.5 (17.6) ; tarsus, 24-28.5 (26) ; middle toe, $26 . \overline{0}-33(29.6)$.

\section{PLUMAGES}

In addition to features mentioned in the technical description quoted, it is stated in the literature that the nestling has a yellow skin covered with sparse, cottony, white down. The nestling studied in Colorado in 1945, however, was covered with cottony down of a peculiar shade of yellow and the skin was not noticeably yellow.

According to Bendire, juvenile birds apparently molt during their first fall. The molt of the adults is not well known. Among specimens collected for the present study some birds were identified by the field collectors as juvenile, but on laboratory examination their crops were found to contain active milk glands. Study of September-collected birds in Colorado in 1945 showed considerable molt under way. Several adult birds had lost most of their crown and face feathers and presented a quilled hedgehog appearance. It was also apparent that soon after the close of nesting activity there is a rather speedy reduction in the prominence of the white neck-ring, especially in the male birds.

\section{COURTSHIP}

Apparently little is recorded concerning the courtship of the bandtail. Bent (1932), quoting Swarth, indicates that cooing and other calls and spectacular circling glides by the male from a perch are among the details of courtship. Pearse (1935) describes another activity, apparently part of the courting behavior. Short flights in a hesitant, quivering manner, during which the bird seems almost to float, form the basis of this display. The tail is fully spread, and Pearse says that the tips of the wings appear to be held down. The display is accompanied by two separate very low calls, one of which he describes as being very like the modified chirping of a cricket.

\section{CALLS}

The deep, cooing notes of the band-tailed pigeon are distinctive. Once heard as they ring through the depths of some mountain canyon they will never be forgotten. Mrs. Florence Merriam Bailey (1902) terms the calls "owl-like." They are most often heard during the courting period, and Wales (1926) describes the tilting of the head downward to horizontal, the inflation of the neck, and other actions incident to the display of that particular period. After nesting has begun, the cooing is more subdued and less frequent.

A variety of low guttural call notes may be heard when the parents are together at or near the nest; these are similar to the notes of the domestic pigeon at such times. The squab, when hungry, utters a thin, piping note. Neither of these latter calls can be heard for more than a few yards. 


\section{BEHAVIOR}

Band-tailed pigeons are very gregarious, consorting in flocks at all seasons except during nesting; even then communal tendencies are exhibited. They are fond of perching for long periods in the tops of tall dead or partially dead trees, but when approached drop quickly away to better concealment. The flight is strong and swift, and in descending mountain sides the birds may dive with wings partially or completely shut. During such swoops the noise of the wind through the rigidly held wing feathers is often audible for a long distance. When the bird takes flight, the wings may be clapped together over the back producing a sound that may be heard for some distance. This seems to be a form of signal; and not the result merely of intense exertion.

\section{NESTING}

\section{NESTING SEASON}

The nesting period of the band-tailed pigeon is lengthy. During practically all the months pigeons may be noted in flocks. Even in the nesting season bands of 5 to 50 birds have been observed. These flocks were once considered to be nonbreeders, but it is now thought that they may be nesting birds. This habit, combined with the usual remote nesting habitat, makes it difficult to obtain accurate information on the number of broods a season and other nesting phenomena. Observers have recorded successive broods from the same nest, without proof, however, that the same adults were concerned. The long nesting period alone has led some observers to believe that at least in the South some bandtails may rear two or possibly three broods. In the northern part of the bird's range it seems that normally only one brood is produced.

In California, Grinnell, Bryant, and Storer (1918) list nests containing eggs or young from March 5 to August 23, and A. C. Oberle (letter of April 15, 1935) says that nesting has been observed on the Laurette Ranch north of San Dimas, Calif., and in Brown's Flat, the first nesting starting about April 1. Eggs were observed into May. Apparently each nest contained but one egg at a time. Abbott (1927) quoted Bushnell's observation of a nest that contained one egg on March 8, 1925, and later a second egg that hatched in mid-May. Moran (1919) relates finding a nest with one well incubated egg on March 30, 1895, at the head of Lopez Canyon, San Luis Obispo County. Grinnell (1928) watched a squab being fed in a nest on September 29, 1927. Stillman (1928) describes a young bird that left its nest in San Diego County on October 2. Kloppenburg (1922) noted a nest in the Plumas National Forest that contained one egg in mid-September. Derby (1920) recorded one containing a naked squab on September 1, 1920 , at 6,500 feet elevation on the headwaters of Deer Creek, Sequoia National Forest. Davis (1938) wrote of the nesting season near Eureka, and Michael (1928) of that in Yosemite National Park. These records seem to bound the outer limits for California. 
Kitchin (Bent 1932) said that the nesting season in Washington lasted from April through June. Einarsen (letter of December $15,1939)$ reported a nest near Triton Cove, Hood's Canal Highway, that on August 24,1939 , contained a squab about a week old. Hagenstein (1936) observed a nest containing a squab near Seattle on October 17, 1935.

Gabrielson and Jewett (1940) report that in Oregon egg-laying is at its height late in May and in June, and give May 3 and July 12 as the known extremes of the season. Later, Jewett (1941) recorded a nest with two eggs in Yamhill County on September 30, 1940.

In Arizona, according to Bendire's correspondents, nesting occurred in nearly every month of the year. Poling, writing to him from Fort Huachuca of various nests, said, "I have taken young two or three months old in February, and since that time young and eggs enough to show that they lay and nest from December to August." Benson reported nesting of the bandtails in the Huachuca Mountains from early July to late October; Willard (1913) noted an October nest; and Vorhies (1928) one in September. On Pinal Mountain south of Globe, Ariz., Carlos Stannard reported nests as follows: August 18, 1940, one egg; August 19, 1940, squab ready to fly; August 23, 1940, a squab about 4 days old which was still in the nest on August 30; and on August 14, 1941, four nests, one with eggs, three with squabs between 1 and 3 weeks old. Considerable field work by the writer, accompanied by State game wardens, leads to the conclusion that in southern Arizona nesting most commonly begins early in May, though occasionally earlier.

For New Mexico, Mrs. Florence Merriam Bailey (1928) lists a number of interesting records, chief among them being that of a nest containing one well-incubated egg on April 23, 1922, 16 miles northeast of Santa $\mathrm{Fe}$, at 10,500 feet elevation, well above the snow line. There are also records for the Animas Mountains, Guadalupe Mountains, Monument Pass, Black Mountains, and the Pecos, Sacramento, Sandia, Taos, Sangre de Cristo, Jemez, and Mogollon Ranges, the dates extending from June 3 to mid-August, and the elevations from 5,800 to 8,000 feet. Of 280 adult bandtails examined by John C. Knox at Mountain Park between June 25 and July 10, 1941, 235 were males, 151 of them with testes indicating active breeding condition, and 45 were females, 22 of which contained well developed eggs.

In Utah, Lee Griner records a bandtail nesting in June, and Clarence Cottam (1941) saw a juvenile recently out of the nest on July 24. In Texas, Ray Williams, State Game Warden, observed a pair of pigeons building a nest on April 22, 1933, in the Davis Mountains, and saw a nest containing an egg in the Chisos Mountains in July of that year.

For Colorado there was until 1945 no definite breeding record substantiated by collection of eggs or young or by photographs of nests. The presence of the birds over a wide range, however, made it certain that they did nest. R. J. Niedrach (Niedrach and Rockwell 1929) of the Colorado Museum of Natural History collected a bird near Kittredge on June 20, 1928, that contained a fully 
formed egg, and in Jarre Canyon near Sedalia on September 11, 1938 , he took several birds that contained active milk cells in their crops. Several State game wardens and woodsmen relate having seen nests in earlier seasons, but none were reported at the time and hence are not verified. Warden Hall, of Montrose, reported that in 1943 on Tabeguache Creek in the Uncompahgre National Forest he saw a number of juvenile birds that were so immature they could not have been long out of the nest.

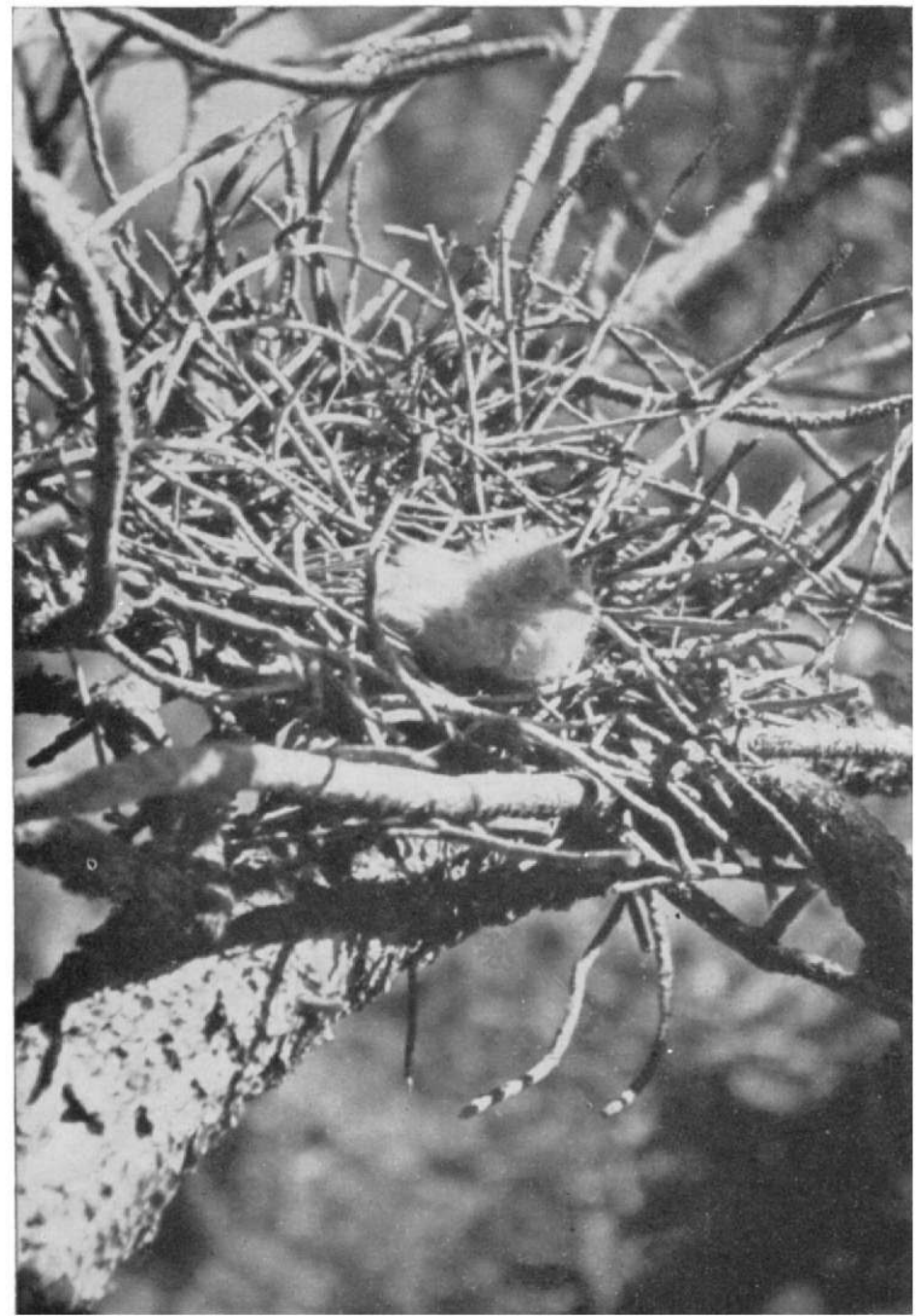

B.62847

Figtre 1.-Nest and day-old young of the band-tailed pigeon in a lodgepole pine on the Rampart Range, Pike National Forest, Colo., August 22, 1945, the fir'st recoriled and authenticated nest of this species for the State. 
On August 22, 1945, the writer found the first recorded and authenticated nest for the State. It was in a lodgepole pine on the summit of the Rampart Range, Pike National Forest, some 55 miles south of Denver, and contained a day-old squab (fig. 1). On August 31, R. J. Niedrach found a second nest nearby containing an older squab. On the basis of information available at the end of 1945 it seems that the major nesting season for Colorado covers the period July 1 to August 30, with a few pairs of bandtails nesting earlier or later.

\section{NEST LOCATION AND STRUCTURE}

The location of band-tailed pigeon nests varies greatly. 0 . B. Johnson (1880), Irene G. Wheelock (1904), and Cooper (1880) report ground nests, but no other similar nestings have been recorded. Johnson observed in the Willamette Valley, Oreg., nests ranging from the top of a stump 8 feet high to the dense branches of a fir at about 180 feet. C. E. Bendire (1892) quotes Ankeny as describing nesting in the Rogue River Valley, Oreg., on limbs of small firs, generally in dense thickets. William Lloyd wrote Bendire that in Texas and in Mexico nests were largely in oaks, and Stephens told him that in Arizona nests were usually in pines at heights of 8 to 20 feet from the ground. Benson and Poling reported nests in Arizona in pines, oaks, and mulberries, at heights of 15 to 70 feet, and from 5,000 to 8,000 feet elevation in the mountains.

E. A. Kitchin, in correspondence with Bent, said that nesting sites in Washington were mainly in dark fir trees, in the lower branches near the trunk, and averaged about 20 feet from the ground. Occasionally nests were found in alder or birch on hillsides. Leo K. Couch informed the writer that around Willapa Harbor, Wash., the bandtails nest in Sitka spruce (Picea sitchensis). Ira N. Gabrielson and Stanley G. Jewett (1940) report that in Oregon the nest is usually high in a coniferous tree.

Grinnell, Bryant, and Storer wrote that most of the California nests were in oaks, at heights of 8 to 30 feet. One was reported in a Douglas fir and one in a California lilac (Ceanothus thyrsiflorus).

Fowler (1903) reported live oaks as favored locations for nests in the Huachuca Mountains of Arizona, the nests being built on low, horizontal limbs from 9 to 12 feet from the ground. In July 1939 the writer, with George Peterson, Deputy State Game Warden, of Nogales, Ariz., visited several of the high oak canyons in the Tumacacori and Washington Camp Mountains near Nogales in search of bandtail nests. About 10 nests, deserted but of the current season, were inspected. All were in oak trees at heights of 12 to 25 feet, in dense woods near the canyon floors. David 0. Scott, of the United States Forest Service, describes a nest found near Williams, Ariz., as being 15 feet up in a yellow pine and very loosely constructed of coarse oak sticks.

The two occupied nests found in 1945 in Colorado, and several unused nests found nearby, were all in lodgepole pine forest at ele- 
vations of approximately 8,400 feet. One nest was in a fork against the trunk, the others one to two feet out on flat limbs; all were 14 to 16 feet above the ground. All were in trees on rims or slopes, with lower vegetation downhill, so that the adults had room for a downward dive upon leaving the nest as they picked up momentum.

The nests (figs. 2 and 3), typical of those of the pigeon family,

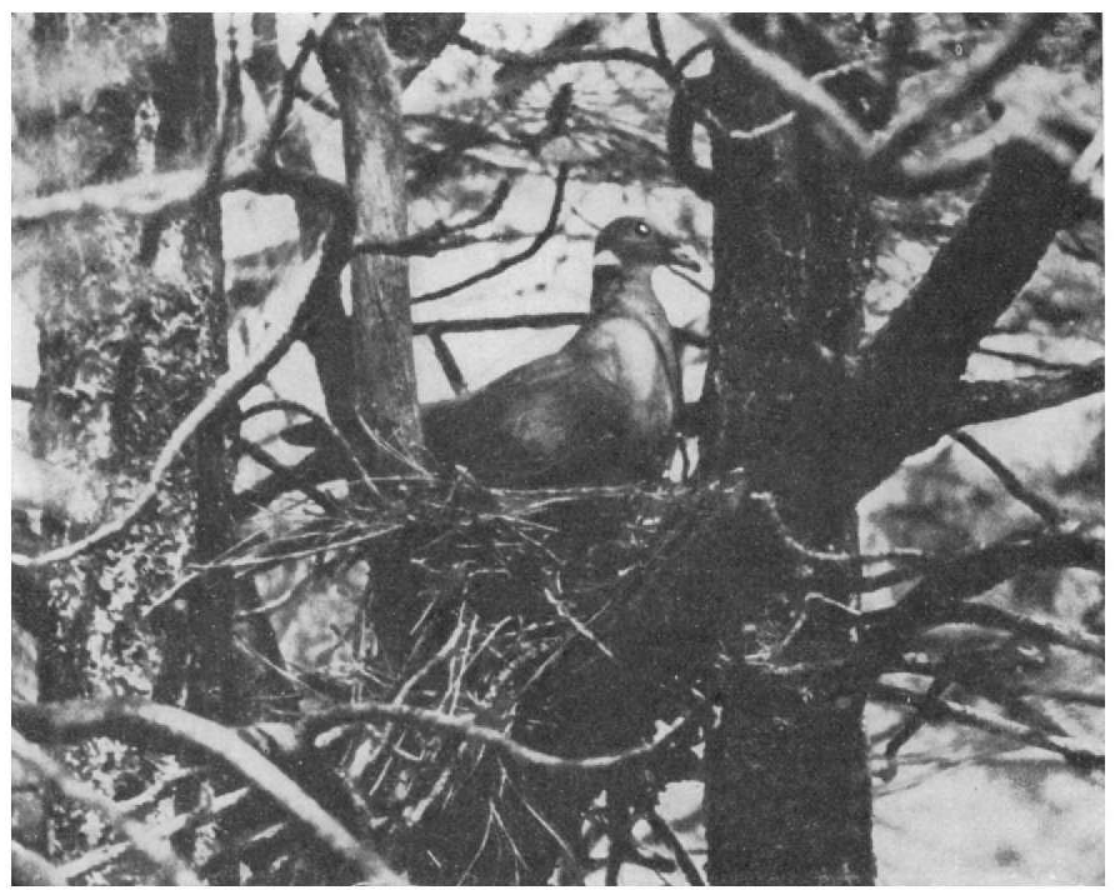

B8714M

Ficure 2.-Band-tailed pigeon on a typical nest in a pine tree on Maverick Mountain, Prescott National Forest, Ariz. (Photographed by Floyd Schroeder, United States Forest Service.)

are usually frail platforms of dead twigs of oak, pine, or other plant stems. The ground nest reported by Johnson (1880) in the Willamette Valley was made of leaves and moss. A nest measured by Grinnell (Grinnell, Bryant, and Storer 1918) was $83 / 4$ inches by 4 inches, exclusive of several protruding twigs. Frequently there are numerous gaps in their structure, the frailty of the nests being generally commented on in the literature. Nests observed by the writer near Nogales, Ariz., in 1939 and 1940 were thin platforms of oak twigs, so fragile as to cause one to wonder how eggs and young could remain on them.

Willard (1916), describing nest building in the Huachuca Mountains of Arizona, says that it was carried on only in the morning hours from sunrise to about 8 a. m., almost entirely by the female, and that she proceeded in a most lackadaisical manner. The period from the placing of the first stick to the laying of the first egg was 6 days. 


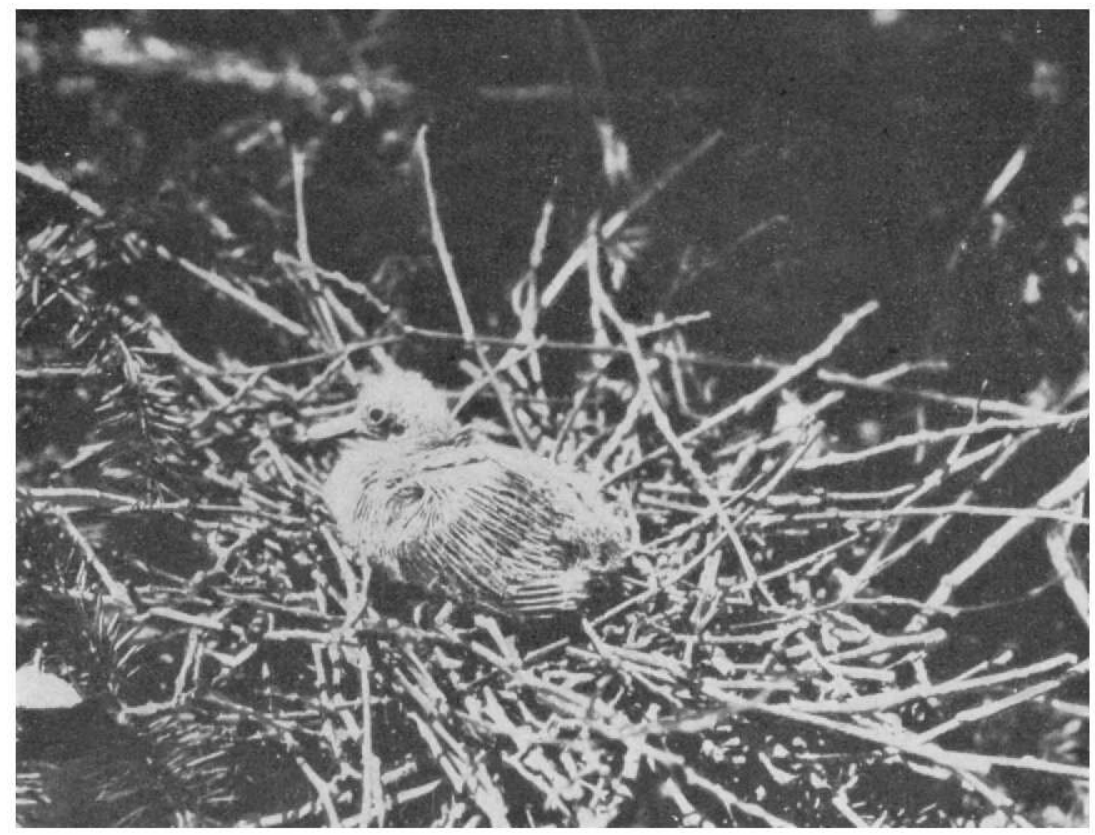

B8713м

Figure 3.-Nest and young of the band-tailed pigeon in the humid coastal area of Tillamook County, Oreg., June 25, 1931. (Photographed by Alex Walker.)

Bent quotes Kitchin as stating that bandtails are very fond of their old nesting sites and that they come back year after year to the same limb even though the previous nest has been disturbed. Kitchin records second nests built on the same spot where an earlier nest of the current season had been robbed or destroyed, and cices one instance of a nest from which he collected the egg being followed by a second nest on the same site from which he again took the egg; later in the season he found in the same place a third nest that he left intact.

Noack (1916) describes the breeding of the band-tailed pigeon in captivity. The first egg laid was removed from the nest and was hatched by a domestic pigeon. Within a few days the bandtail laid another egg, which was hatched and the young bird raised. Then a third egg was laid and a second squab reared to maturity.

\section{COMMUNAL NATURE IN NESTING}

Usually the band-tailed pigeon nests in widely separated pairs. Fowler (1903), however, describes a community breeding ground near Fort Huachuca, Ariz., where some 35 pairs nested in a loose rookery; in the area most thickly populated there was one nest to each 3 or 4 acres. Observations by George Peterson, Deputy State Game Warden, of Nogales, in 1936 in the Tumacacori Mountain range northwest of Nogales, Ariz., were of the same purport. The community nesting ground was in dense vegetation along the bot- 
tom of a steep canyon at an elevation of about 6,000 feet. Inspection of recently deserted nests in that canyon and others by Peterson and the writer in 1939 and 1940 showed that nests were irregularly spaced along the bottom of the canyon, sometimes within a few yards of each other, but usually fairly widely separated.

Surprising examples of community nesting are contained in two notes transmitted by H. Garvin Smith, of the United States Forest Service, Tucson, Ariz. He says that in 1933, while camping in the Magdalena Mountains of New Mexico he found 14 bandtail nests in one large Douglas fir near a spring, and that in 1934 in the same tree he found 17 nests, one of which contained two eggs, the others one each.

Fred Herman, of Sanborn Park, Montrose County, Colo., relates that a former Forest Service employee described a number of "colony trees" that he had seen among the thick, bushy conifers along the rimrock above Horsefly Creek Canyon north of Sanborn Park, and that he had also found the pigeons nesting in blowholes and on ledges in the sandstone rimrock along Big Red Creek Canyon nearby. Several other Colorado game wardens have reported bandtail activity about similar rimrock areas and they feel sure that pigeons nest there.

\section{EGGS}

The usual, or normal, deposition is one egg to a nest, but in the literature are a number of records of two eggs. In a tabulation covering 18 nests in California, Grinnell, Bryant, and Storer (1918) report one nest containing two eggs and one containing two squabs. O. B. Johnson (1880) observed two nests in the Willamette Valley, Oreg., that contained two eggs each. Bendire quotes Ankeny as saying that two eggs were laid in nests in the Rogue River Valley, and Lloyd as describing two-egg sets in Texas and in the Sierra Madre of Mexico. Cooper (1880) also said that the set was two eggs. On the other hand, Bendire quotes Benson, Stephens, and Poling as stating that only one egg to a nest was laid in the Huachuca Mountains of Arizona. Jewett (1941) reports a two-egg nest in Yamhill County, Oreg., on September 30, 1940, and H. Garvin Smith writes that he has seen several twoegg nests in New Mexico.

Ralph Morrow, Deputy State Game Warden, of Hilltop, Ariz., observed "several" nests in the Chiricahua Mountains, in each of which were a half-grown squab and one egg. G. W. Peterson, Deputy State Game Warden, of Nogales, Ariz., said that during June 1936 in canyons of the Tumacacori Range northwest of Nogales he inspected 56 bandtail nests, 11 of which contained two eggs.

The eggs of the band-tailed pigeon are elliptical-ovate, somewhat pointed, smooth, pure white, and with a slight gloss. A series reported by Bent averaged 39.7 by 27.9 millimeters in dimensions. ( 25.4 millimeters $=1$ inch.)

\section{INCUBATION}

According to Bendire (1892), incubation lasts 15 to 18 days; 
even longer periods should not be exceptional in some of the earlyseason nests at high altitudes where the weather is still very cold.

\section{GROWTH OF THE YOUNG}

Doves and pigeons differ from all other birds in feeding their nestlings a substance, usually called "pigeon milk," that is developed in the crops of both the male and the female adult. It is creamy-colored and somewhat similar in appearance and consistency to curd. Feeding is by regurgitation, and for the first few days after the nestlings are hatched this "milk" is their only food.

Little is known of the development of this secretion in the bandtail. Even in regard to the domestic pigeon the literature lacks information on some phases that are of interest; but since the domestic pigeon incubates for 18 days and the young remain in the nest for at least 30 days, it seems probable that the development of the pigeon milk and the duration of the supply may be similar in the two species. The most detailed discussion of the phenomenon of pigeon milk that the writer has found is one that is contained in the literature on the domestic pigeon, and is here briefly summarized. About the 8th day of incubation the lobes of the pigeon's crop begin to increase in size through multiplication of the cells of the outer, or proliferating, layer; by the 12th day the walls of the lobes are obviously thickened and enlarged and on the 18th day they are at their greatest development. The inner layer of each lobe has been pushed farther away from the source of blood in the outer layer, and it begins to degenerate; globules of fat develop in the cells, and whitish masses of dead cells begin to peel off. By the time the eggs hatch on the 18th day these greasy masses are sufficient to furnish the entire food of the squabs during their first few days of life. After the first few days the regurgitated material begins to contain some quantity of seeds and other solids that have been softened in the crop of the adults. It is said that the duration of the milk supply varies considerably in the different families of the domestic pigeon, and that in some it has ceased to form by the time the young are 7 days old, whereas in others approximately half of the food is still "milk" when the young have reached 10 days of age.

Bendire (1892) states that both sexes assist in the care of the young. "The young grow rapidly and are able to leave the nest when about a month old." Mrs. Wheelock (1904) says that the squab is "fed on a thin milky fluid, by regurgitation, for 20 days."

Considerable food must be administered at a feeding, as the squabs maintain continued rapid growth with a minimum of parental visits. Abbott (1927) published notes from A. E. Stillman, of San Diego County, Calif., dated September 17, 1922, as follows: "That day the female left the oak tree in the early morning and returned at twilight; after quickly feeding the young she left. again. Next day she left at daybreak and returned at sundown." This squab, according to Abbott, left the nest and tree on October 2.

Under date of November 9, 1939, Carlos Stannard, of Phoenix, Ariz., wrote: 
We camped near the top of Pinal Peak, about eight miles south of Globe, Ariz., at about 7,500 feet. In a small yellow pine just over our tent was a band-tailed pigeon's nest with one young. It was about a week old on August 13. I watched the nest pretty steadily for a number of days; we were in that camp until August 31. No adult stayed on the nest during the day after we went there. And after the 16th no adult stayed on the nest during the night. The young left the nest on the 25 th but did not leave the tree; it was still in the tree on the morning of the 31 st. During the time we were there the young was fed once each day by the female, usually shortly after sunrise, and once by the male about 8 or 9 a.m. I banded all three. The adults seemed to pay no more attention to us than if we were cattle.

After the discovery of the two nests in Colorado in August 1945, the writer made every effort to recheck existing information on the growth of the young. As R. J. Niedrach was making a photographic record of these first Colorado nests, the adults were not disturbed as frequently as would have been desirable to obtain full data on growth, but some observations were made on the two nests. At one day of age the squab was a tiny helpless creature about 2 inches long, unable to hold up its head for more than a few seconds. The female parent was on the nest when it was found at 2 p. m. on August 22, and she remained on the nest during the daylight hours of August 24. The male was on the nest during most of the day of August 23. During the remainder of the study the adults followed this routine: The male returned to the nest between $8: 45$ and $9: 30$ a. $\mathrm{m}$. each day and brooded the young bird during the day (fig. 4 ). The female returned to the

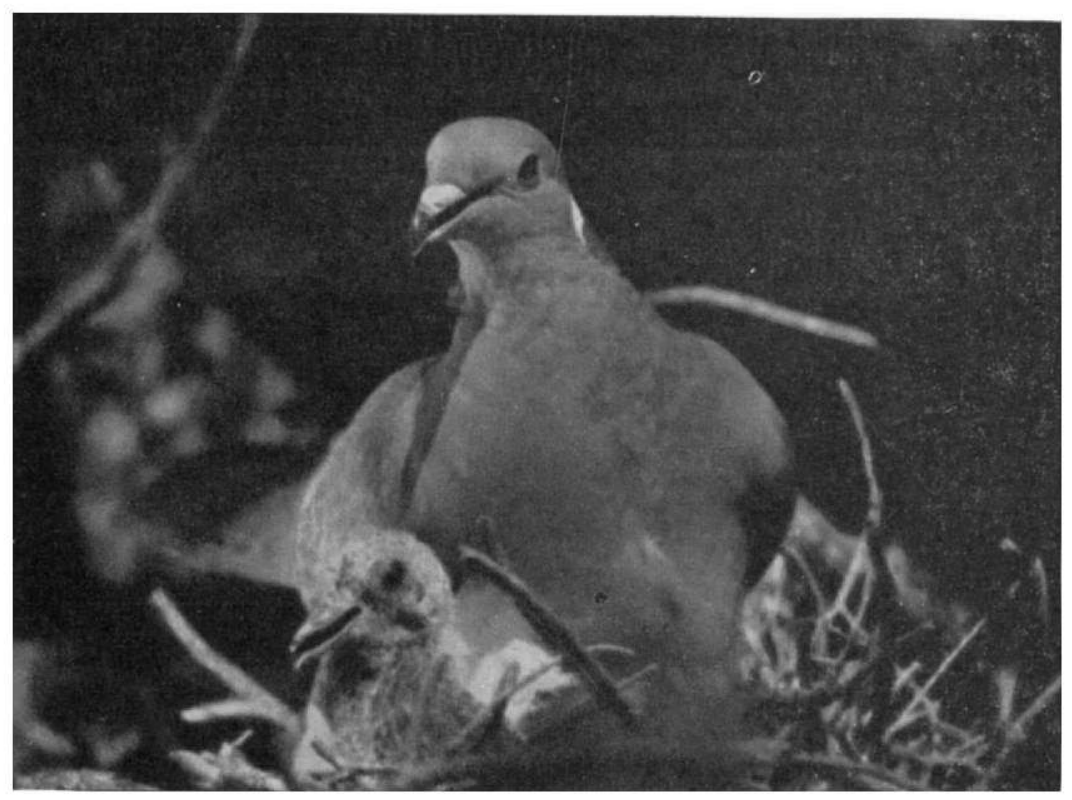

Figure 4.-Male band-tailed pigeon on nest hovering a ten-day-old squab. Rampart Range, Pike National Forest, Colo. August 31, 1945. (Photo graphed by $\mathbf{R}$. J. Niedrach.) 
nest at any time between $3: 45$ and $5: 15 \mathrm{p} . \mathrm{m}$. She was not observed feeding the youngster, though she undoubtedly must have fed it. Watched from dawn until dark, the tiny squab appeared to sleep until after the return of the male. During the first week about three feedings, all between noon and 3 p.m., seemed to be the schedule. As the youngster's food capacity grew, the number of feedings was reduced to two, and the period of regurgitation indicated that a large quantity of food was taken. Both feedings were about midday.

Contrary to Stannard's observation, the adults continued to hover the squab, both day and night, until it was 20 days old. On that date they stopped abruptly and did not return to the nest during either the day or the night except to feed the squab. Each parent came to the nest once daily, between 10 and $11 \mathrm{a} . \mathrm{m}$., fed the squab, and departed. Occasionally during the day one of the parents would visit the vicinity, scan the nest and its surroundings carefully, and then depart.

During the first 10 days the young squab did not grow very rapidly. It slept most of the day and increased in size, but the feather development seemed to be slow. After about 12 days feather development began visibly to progress. At 17 days of age one of the squabs was well covered with feathers, the body feathers being about $15 \mathrm{~mm}$. out of the sheath and the first primary $30 \mathrm{~mm}$. out of the sheath; the tail feathers measured $28 \mathrm{~mm}$. from the tip of the tail flesh to the tip of the feathers; the head was heavily pinfeathered but had no open feathers, and the sides were quite bare. The yellowish brown down adhered to the tips of the feathers, giving the squab a peculiar fuzzy appearance. At this age the youngster crawled clumsily about over the nest and snapped its beak furiously at the intruder. It weighed 140 grams, or 4.9 ounces. External examination indicated that the crop was well filled with pigeon milk.

When the squab was 20 days old the tail feathers measured 42 $\mathrm{mm}$. in length and the first primary was $40 \mathrm{~mm}$. out of the sheath ; the pinfeathers on the head were opening but the sides were still quite bare. When it was 23 days of age its outward appearance had changed little (fig. 5), but when the writer's hand approached, the young bird snapped its beak vigorously, struck with bent wing, and danced awkwardly about over the nest. When the squab was 26 days old it weighed 243 grams and its tail measured $75 \mathrm{~mm}$. For the first time it spent much time preening, apparently picking off the down that still adhered to the tips of the feathers. On that day also, one of the squabs began to exercise and spent much of the day walking about, for the first time venturing off the nest onto the nest branch, waving and flapping its wings, and craning and peering about with interest. This was repeated on the 27 th day, and on the 30th day the bird was gone from the nest, tree, and immediate area. The other squab was not observed between its 20 th and 26th day, but on the latter day it was sitting quietly on the nest without apparent interest in exercising. The nest was not again visited.

Nowhere in the literature examined has the writer found any $695766^{\circ}-47-2$ 


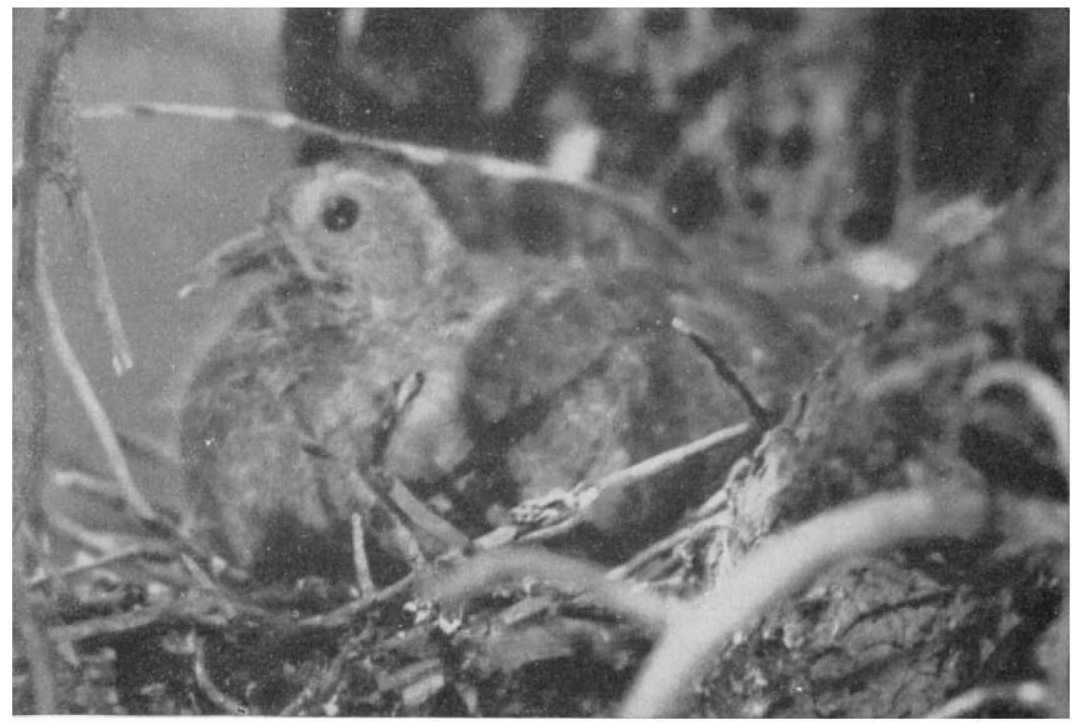

Figtike 5.-Young band-tailed pigeon about 24 days old on nest. Note the high degref of camonflage afforded by the nest, trunk and branches of the tree, and the low-sitting, quiet habits of the young bird. Rampart Range, Pike National Forest, Colo. September 3, 1945. (Photographed by R. J. Niedrach.)

information on how long the lobes of the crops of the adult bandtails remain enlarged and thickened, with easily distinguishabie milk cells, after the period of active feeding of 'milk' to the young. Knowledge of the length of time that the young bandtail is fed 'milk' is incomplete, but one squab examined in 1945 appeared to have its crop well filled with the soft curdlike 'milk' on the 17th day. Just how long this material, alone or in combination with softened seeds and grains, makes up a part of the food of the squab and how long thereafter the thickened, whitish milk-cell pads remain easily distinguishable in the lobes of the crop of the adult after the 'milk' has ceased to be an item of food for the young are not yet known.

On numerous occasions adult pigeons collected for study or shot by hunters on dates well outside the normal nesting season have carried well defined milk pads in their crops; others have contained variable remnants of the thickened crop-lobe walls. In some instances observations indicated that the birds still had young in nearby nests; in others that they apparently were migrants. Among such late-season records of bandtails containing well defined milk pads in their crops are those of birds taken in Washington, September 22 and 26 and October 2; in Oregon, September 8 and October 3; in Arizona, September 29; in New Mexico, September 23; and in Colorado, September 15 to 20. In southwestern Colorado in 1944 a majority of the birds examined by United States Game Management Agent Frank F. Poley from 
September 16 to 20 contained this evidence of recent feeding of young, and in New Mexico as late as September 23, 9 out of 34 birds examined showed a similar condition. Until the correlation between disappearance of the milk-cell pads and the 'weaning' of the squab by its parents is definitely established, accurate analysis of these observations is impossible.

\section{NATURAL ENEMIES AND DISEASE}

The few instances of molestation of bandtails recorded in the available literature are those by Willard (1916), who said that in Arizona "the Prairie Falcon and Cooper Hawk take considerable toll from the flocks;" by Kitchin (Bent 1932), who remarked that in Washington a gray squirrel occasionally took possession of a pigeon nest, using it as a foundation and adding to it to suit itself; and S. D. Durrant, whose Hanna, Utah, specimen was struck from a flock by a sharp-shinned hawk (Cottam, letter of May 6, 1940). McLean (1925) reports that a western goshawk pursued bandtails in Yosemite National Park. No doubt there is some predation upon eggs and squabs, but no data are available.

One adult pigeon collected near Durango, Colo., in July 1945 was found to contain at least 12 flatworms in its abdominal cavity.

Sick pigeons were reported from Whidby Island, Wash., between September 8 and 21, 1939. All were found close about waterholes. Reports from United States Game Management Agent Bach mention six birds found dead by Washington State game protectors and three still able to fly weakly, which were shot. Six specimens were sent to Dr. Karl F. Meyer, Hooper Foundation, University of California, who found no evidence of poisoning or of bacterial disease. Dr. Meyer reported hemorrhages in the gizzard and evidence of acute irritation in the intestinal lining, but the causes were unknown.

The band-tailed pigeon seems to be relatively free from natural enemies; the birds feed on the ground with little apparent fear, and perch conspicuously in the tops of dead trees. One beneficial result of their flocking habit is that individual safety is enhanced by the combined watchfulness of all the birds of the flock. Man through shooting the birds and clearing and destroying their nesting range, appears to be the only enemy of importance.

\section{DISTRIBUTION}

\section{GENERAL RANGE}

As recorded in the American Ornithologists' Union Check-List of North American Birds, fourth edition, 1931, the range of $\mathrm{Co}$ lumba fasciata fasciata is as follows:

Breeds in the Transition Zone from southwestern British Columbia, Montana, and north-central Colorado south through the southwestern United States and Mexico to Guatemala, and east to western Texas. Winters from the southwestern United States southward. Accidental in North Dakota.

Library research and correspondence have been undertaken to 
obtain a concept of the bird's range at the present time. The results are here presented, beginning in the northwest and moving southward and eastward.

\section{SUMMER RANGE}

The summer range of the band-tailed pigeon is shown in figure 6 .

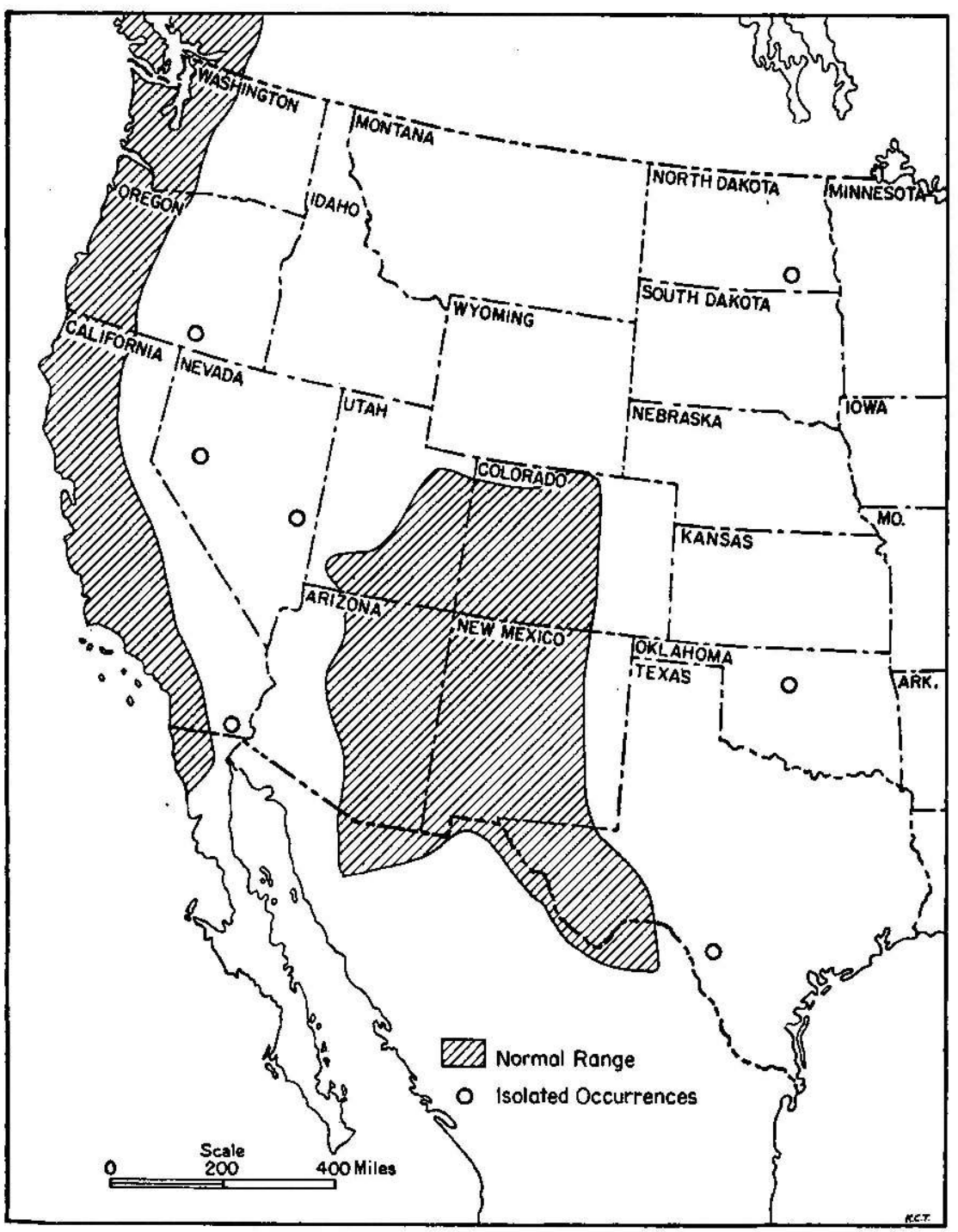

FigurE 6.-The summer range of the band-tailed pigeon. (In Canada, north to Bella Coola and Grabam Island.) In Arizona, Colorado, New Mexico, Texas, and Utah, large expanses of range grassland and semi-arid desert may separate the mountain ranges in which pigeons are found. The range as shown in the map covers the extreme distribution as known from existing records. 
In British Columbia, Taverner (1934) says that the species is found west of the Coast Range, north at least to Bella Coola on the mainland and Tow Hill, Graham Island, and Queen Charlotte group along the coast. According to Bent (1932), Courtenay and Chilliwack are the normal limits of range, hence the southern half of Vancouver Island may be considered the area normally inhabited by the birds.

In Washington, as in Oregon, bandtails breed locally in varying density west of the Cascades, and probably erratically in the Transition and Upper Sonoran Zones of the eastern slopes. The coastal belt and the area adjacent to Puget Sound seems to be the center of their abundance in the State. John Finley, of the Fish and Wildlife Service, at Olympia, says that the most easterly record he has obtained was near Bingen, Klickitat County, on the Columbia River.

In Oregon, Gabrielson and Jewett (1940) report that the species is common in the western part of the State, its greatest abundance being reached on the coast (fig. 7). Breeding in Oregon,

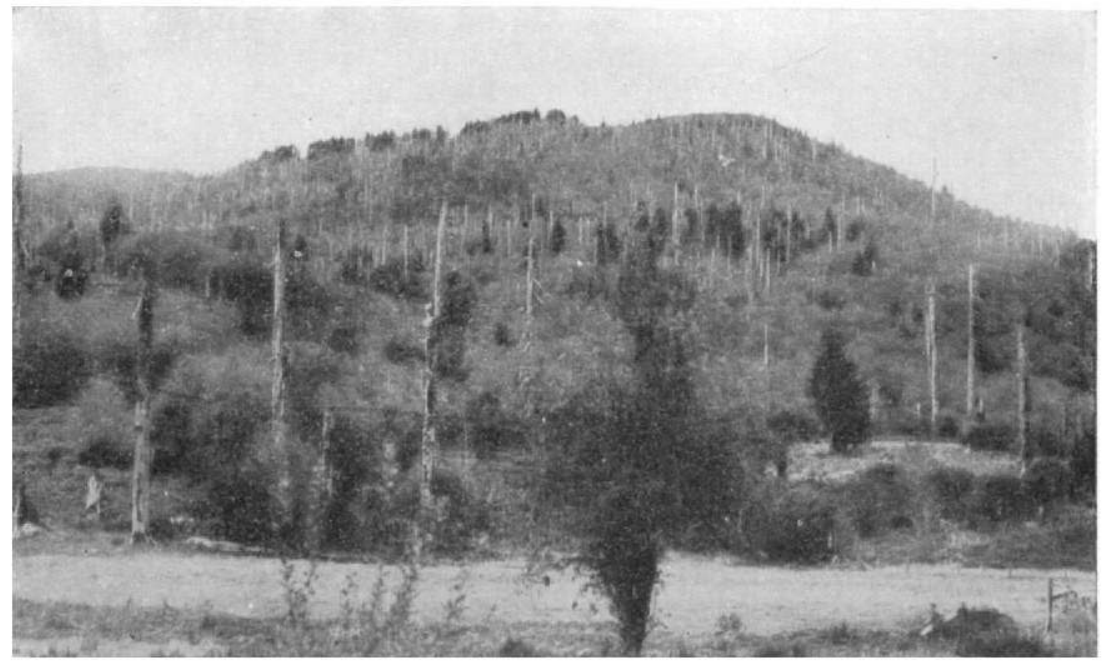

B8710M

Freure 7.-Typical banrl-tailed pigeon habitat in a "burn" in the Oregon coastal mountains, in Tillamook County, where the luxuriant vegetation offel's both food and nesting cover. (Photographed by A. S. Einarsen, September 10, 1940.)

as elsewhere, is erratic. Pigeons may rarely be seen on the eastern slopes of the Cascades, and the only record for the State at any distance east of this range is of a lone, immature bird collected by Jewett in the Steens Mountains in Harney County on October $19,1928$.

In California band-tailed pigeons nest locally and erratically in Transition and Upper Sonoran Zone areas west of the Sierra Nevada divide, chiefly in mountainous areas from Del Norte and Siskiyou Counties in the north to the Laguna Mountains of San Diego 
County. Their choice of nesting habitat apparently depends to a considerable degree on temperature. In the southern mountains, in the Sierras, and in the more northerly interior mountains nesting areas are usually at high elevations, but near the coast and in the coastal mountains they are scattered widely at much lower elevations, including the coastal redwood belt. According to Captain W. J. Harp, California Division of Fish and Game, the pigeons nest locally in fair numbers near the small ranches of Humboldt and Del Norte Counties in northwestern California.

Bandtails have been listed in so many publications on California birds that it is unnecessary to mention them all; Grinnell and Wythe (1927) describe the species as a summer resident locally in the coastal belt just north of San Francisco Bay; George Willett (1933) says that in southern California it breeds in moderate numbers in the oaks of the Transition Zone, mostly above 3,000 feet, south to southern San Diego County; Grinnell and Storer (1924) record it as being in Yosemite Valley during the nesting season; Derby (1920) describes a nest in the Sequoia National Forest; and Kloppenburg (1922) reports one in the Plumas National Forest. These records outline roughly the outer limits of the range within which band-tailed pigeons may be observed during the summer where habitat is favorable.

On October 4, 1941, Luther C. Goldman, of the Fish and Wildlife Service, collected a migrating band-tailed pigeon at a point 7 miles east of Calexico, 3 miles north of the Mexican line. This constitutes, so far as the writer knows, the first record of the species from the floor of the Imperial Valley.

In Nevada, Leo K. Couch reported observing a mature bandtail near Success Divide, Duck Creek Range, Nevada National Forest, on November 4, 1943.

In Utah, band-tailed pigeons have been observed at several points during the breeding season, and nests have been found in at least one district. Benson (1935) collected a pigeon in the Navajo Mountains on June 20, 1935, and Presnall (1935) described the bird as uncommon on the western rim of Zion National Park. According to Cottam (letter of May 6, 1940), S. D. Durrant obtained a specimen killed by a hawk near Hanna, Utah, in 1930; the specimen is now in the collection of the University of Utah. Cottam (1941) summarized the status of the species in Utah, stating that apparently the birds were annual, summer residents in the mountains of southern Utah although probably never abundant anywhere in the State. He reported 20 bandtails seen on July 24, 1940, at Oak Grove and Bitter Creek Canyon, on the south slope of Pine Valley Mountain, one of them believed to be a juvenile only recently out of the nest. He said that W. G. MacFarland saw a flock at Buckboard Flat, Blue Mountains, in June 1939 at about 8,000 feet elevation. Lee Griner is reported to have observed two flocks totaling 32 birds in the same mountain range 8 miles west of La Sal, Utah, on August 18, 1937, at 8,200 feet elevation, and a flock of 57 birds the same day a mile east of North Creek, at 7,800 feet. Griner also saw the birds and found their nests in June 1937 at Oak Grove, Pine Valley Mountain. Evidence obtained by 
Griner from local observers indicated that the birds had occurred there each summer for at least the last 6 years. In June 1931 and 1932, Cottam reported that flocks of bandtails caused damage to fruit in a small cherry orchard at New Harmony on the east slope of Pine Mountain Valley, and Oscar Deming stated that in 1937 the birds frequented this same mountain from mid-May to October.

In Colorado the bandtail has been found in suitable foothill and mountain environment in the Transition and Upper Sonoran life zones on both sides of the Continental Divide. Numerous records obtained from the Colorado Museum of Natural History, the Colorado State Game and Fish Commission, and the field personnel of the Forest Service and the Fish and Wildlife Service, and reports from farmers and sportmen show that pigeons have been seen at some time in 42 counties.

Those counties in which the pigeon population is considered as moderate to large include Archuleta, Conejos, Dolores, Douglas, Eagle, Gunnison, Huerfano, La Plata, Las Animas, Montrose, Ouray, Pitkin, Pueblo, Rio Grande, and San Miguel. Counties with small to moderate populations include Alamosa, Bent, Boulder, Chaffee, Clear Creek, Costilla, Custer, Delta, El Paso, Fremont, Garfield, Gilpin, Grand, Hinsdale, Jefferson, Mesa, Mineral, Montezuma, Park, Rio Blanco, Saguache, San Juan, Summit, and Teller. In several other counties pigeons have been seen occasionally and intermittently; these include Elbert, Jackson, Lake, Larimer, and Weld Counties.

Reports indicate extreme erraticism in much of the Colorado range; in some counties pigeons are more numerous now than for some years, while in others none has been seen for several seasons, and in others there is a noticeable fluctuation in numbers from year to year. Occasional reports from old residents indicate that fifty years ago large numbers of pigeons existed in some parts of Colorado. Food conditions undoubtedly explain many of these variations. The bulk of the birds at the present time seems to occur south of a line drawn from Montrose to Pueblo along United States Highway 50.

A Forest Service report for the year 1942 shows that pigeons were observed during that year on the Cochetopa, Holy Cross, Montezuma, Rio Grande, Roosevelt, San Isabel, San Juan, and Uncompahgre National Forests. The total reported as actually counted was 3,032. The San Juan Forest led with 1,200 pigeons.

Colorado is the northeastward margin of range for the species, and for that reason variations would be expected to occur, especially in counties along the east base of the mountains and at the north. Extensive field work is necessary before the status and range of the bandtails can be definitely outlined for Colorado.

In Arizona, Swarth (1914) gave the range of the species as follows :

A common summer resident in suitable localities throughout the state; that is, in the higher mountain ranges, breeding usually above 6,000 feet. Has been found in summer on San Francisco Mountain, Mount Graham, and the White, Mogollon, Santa Catalina, Huachuca, and Carmelita Mountains. 
Specimens were collected north of Williams, and a nest was found south of tilat town, in 1937, and specimens were also collected in 1941. South and southeast of Williams bandtails are seen in fair numbers annually at many places in the Prescott National Forest. They also occur in some numbers in Oak Creek Canyon south of Flagstaff. They have been observed on numerous occasions in the Coconino, Tonto, and Sitgreaves National Forests. In June 1941 Charles C. Sperry found them abundant near Jacob's Lake in the northern end of the Kaibab National Forest.

Clifford C. Presnall noted several pairs near Hilltop, San Carlos Indian Reservation, on May 15, 1941, and in June of the same year saw paired pigeons at several places in the Fort Apache Indian Reservation. The birds are also frequently observed near McNary and Springerville, and in many places in Greenlee County. They nest in the higher elevations of the Crook National Forest near Globe, on Pinal Peak, in the Pinaleno Mountains of Graham County (fig. 8), and in the Santa Catalina, Chiricahua, and

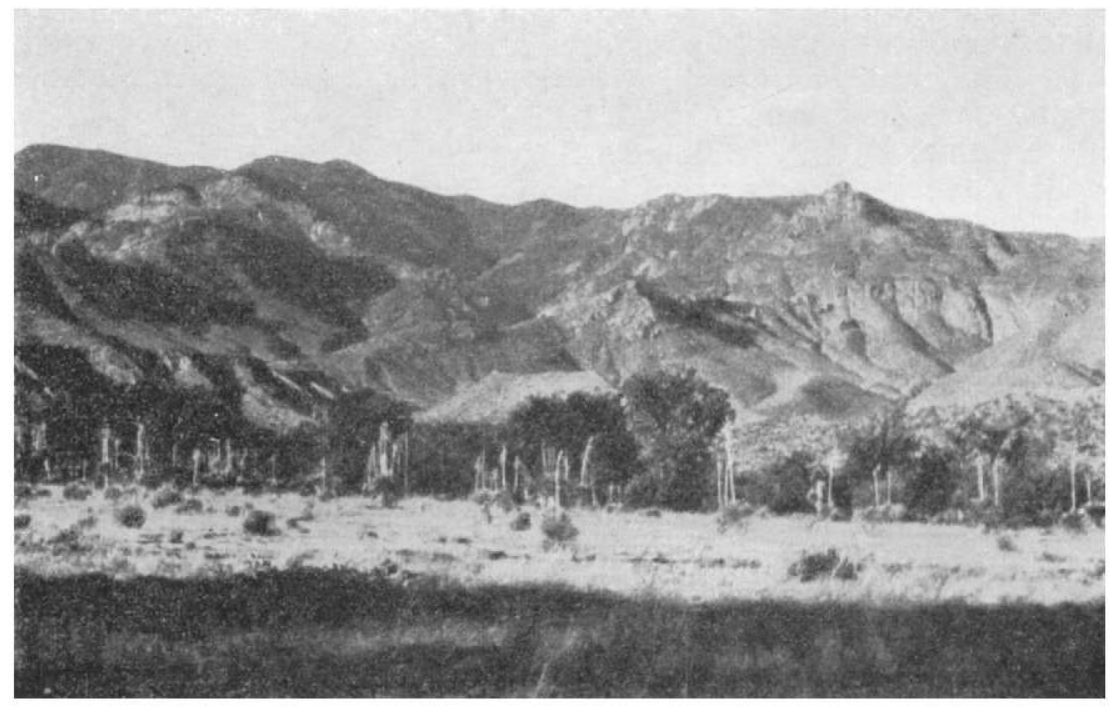

B8709M

Figure 8.-Band-tailed pigeon range in the oak-and-pine-covered Pinaleno Mountains of Arizona.

Huachuca ranges to the southward. Large numbers of them were seen on numerous occasions in the mountains between Patagonia and Nogales and in the ranges to the west of Nogales.

Mrs. Florence Merriam Bailey (1928) says that in New Mexico "the occurrence of the Band-tailed Pigeon at any given place seems to vary in different years according to the food supply. This is especially true of the oak-covered mountain slopes which may swarm with the birds when there is a heavy crop of acorns and be entirely deserted during a whole year when the acorn crop is a failure." She adds that the birds usually occurred at 6,000 to 8,000 feet, but frequently ranged much higher in the autumn, and 
gives examples of observations in the Mimbres Range at 9,000 feet and on Pecos Baldy and in the Jemez Mountains at 10,000 feet.

L. W. Simmons, Deputy State Game Warden, informed L. J. Merovka, United States Game Management Agent, that he saw bandtails near Tererro on June 25 and July 7, 1940. He estimated that there were 250 of the birds, and said that they remained in the area until September 12. He also reported 115 on Cow Creek near Upper Colomas and 100 near Lower Colomas on July 15, 1940. W. M. Wilson wrote Merovka on October 2, 1940, that pigeons came into the Burro Mountains early in May 1939, nested, and left early in October. The birds concentrated well up the mountains. In 1940 pigeons were again present but widely scattered. Fred Sherman, of Deming, also reported to Merovka many past observations of bandtails in the Burro Mountains and the Black Range, and in 1940 some observations near White Signal in the Burro Mountains, and in the Black Range near Mimbres, Pinos Altos, and Kingston.

H. Garvin Smith, of the United States Forest Service, has supplied from his notes records ranging back to 1919 , when he stated that bandtails in large flocks almost ruined the cherry crop at High Rolls and Orchard Park. In 1925 he said that in the Black Range pigeons were everywhere, gorging on piñon nuts; that thousands passed over his camp flying to roost; and that they were also reported from the San Mateo Mountains. By contrast, in 1926 his notes record that pigeons were very scarce in the Mogollons and on the west side of the Black Range. He also observed nesting birds in the Magdalena Mountains in 1933 and 1934.

David O. Scott, ranger in the Carson National Forest, Penasco, wrote that he saw his first pigeon for the year on May 19, 1941; he concluded that bandtails were relatively scarce in that area, though there were at times small groups of them in Santa Barbara Canyon and near Rio Pueblo. Dean M. Earl, of Carlsbad, reported that the only time he saw pigeons on the Lincoln National Forest was in the fall.

Clifford C. Presnall and other employees of the Fish and Wildlife Service saw about 400 bandtails on May 30,1941, near Whitetail School, on the Mescalero Indian Reservation, and single birds at other places on the reservation. D. Wood, Jr., one of the observers, said that during previous employment on that reservation, between 1931 and 1933, he saw many pigeons in small flocks, and that he believed they nested near Carizzo Springs. They have been reported from Sarca Canyon, Capulin Springs, and other places in the Sandia Mountains near Albuquerque.

L. J. Merovka said that band-tailed pigeons are usually fairly numerous around Bland, Senorita, and La Jara Canyons in the Jemez Mountains, and that he saw 500 in the latter place in September 1943. He also reported a flock from Stone Canyon in the Black Range, and on June 13, 1944, he noted a flock near Amalia, on the Costilla River, a few miles south of the Colorado State line.

Few early references to the range of the species in western Texas were found. One specimen from Uvalde was examined; Van Tyne and Sutton (1937) listed the birds from Presidio and Brew- 
ster Counties; and Oberholser (1902) reported them from the Chisos, Guadalupe, and Davis Mountains. Ray Williams, State Warden, of Alpine, Texas, wrote Merovka that in the TransPecos area bandtails ranged from 5,700 to 8,700 feet elevation in the Sierra Madre and the Glass Mountains of Pecos and Brewster Counties, in the Eagle Mountains of Hudspeth County, in the Diablo and Guadalupe Mountains, and in the Davis and Chisos ranges.

Casual records are listed by Carter and Trentoon (Nice 1924), including that of one bandtail killed near Crescent, Logan County, Okla., in 1905. Schufeldt (1912) reported the taking of a single specimen near Englevale, N. Dak., on June 2, 1912. Alcorn (1941) reported the collecting of the first specimen from Nevada near Fallon on October 17, 1940.

In Mexico, according to information furnished by Frederick C. Lincoln, bandtails nest as far south as Durango (Otmapa Ranch), Puebla (Las Vegas), probably Vera Cruz (Jalapa), and the San Jose Mountains in Sonora. They are also found in Baja California. Bandtails were seen by the writer in considerable numbers in June and July 1942 along the Rio de Los Alamos south of Nogales, Sonora, and near Cananea, and along the Rio Babasac near Cocospera. American sportsmen report them widely distributed in the mountains of northern Sonora.

\section{WINTER RANGE}

In the northern part of their range band-tailed pigeons are largely migratory, only a few scattered birds remaining during the winter in sheltered locations. An Audubon Society Christmas Bird Census in the Puget Sound area in 1935 tallied 30 pigeons, and W. H. Ransom, in a letter of April 15, 1939, said that "small bunches quite regularly winter around Medina and Bellevue, Wash., along the east side of Lake Washington." On January 18, 1928, near Agnes, Oreg., a flock of about 150 pigeons feeding on madrona berries was reported to $\mathrm{S}$. G. Jewett, and a few days later he found pigeon feathers along a trail in that vicinity. Jewett also observed a large flock feeding in stubble near Wolf Creek, Oreg., March 20, 1925, and A. W. Moore saw two birds on the Nehalem River in Oregon on February 22, 1940.

In California relatively few pigeons winter in the Sierras north of Yosemite National Park or in the coastal mountains north of San Francisco Bay. Hence the great majority of the bandtails breed from San Francisco Bay northward and concentrate in winter in west-central and southern California. The chief wintering area lies in the Sierras from Yosemite southward to Mexico, and in the coastal mountains from Santa Cruz and Santa Clara Counties southward to the Tehachapi range and Los Angeles, usually centering in Monterey, San Luis Obispo, and Santa Barbara Counties. In some years, the major wintering grounds may be from Los Angeles and San Bernardino Counties southward.

Moderate but irregular numbers of pigeons occasionally winter in the counties just north of San Francisco Bay, and casual winter 
resident bands may at times frequent the slopes on either side of the Sacramento Valley to Redding.

The wintering range in California is closely correlated with food supply, but concentrated shooting during any one season undoubtedly causes the population of the area affected to diminish during succeeding seasons even though food is abundant. Mrs. Mary Bartol (1940) described the (to her) immense population of the Mount Pinos area in Ventura County in 1933, and remarked that only one year since then had been characterized by a crop of piñon nuts and a consequent large population of pigeons; she also said that in one of the intervening seasons the shooting area for southern California was in the oak country of the Santa Ynez Valley of Santa Barbara County.

Fred H. Post, State Game Warden, of Salinas, Calif., told the writer that in the winter of 1932-33 the birds had been very abundant in the mountains of that county. In 1933 food was scarce in the high areas and the birds scattered everywhere. In 1934 food was again plentiful and the pigeons were abundant in December. Other State game wardens in California have described to the writer large midwinter concentrations in areas of abundant food and have told of the annual fluctuation in abundance and distribution occasioned by variation in the food supply.

Grinnell and Wythe (1927) list the bandtail as a winter resident in the San Francisco Bay region, irregular but sometimes occurring in large numbers and in widespread areas. Willett (1933) records it as sporadically plentiful in southern California in foothills and mountains up to snow line, and also as having been observed on Catalina Island in 1932.

In Arizona, New Mexico, and Texas band-tailed pigeons from the northward and from the mountain ranges of those States move toward their southern boundaries or on into Mexico to winter. Variable numbers, however, remain in mountain ranges near the border as food supply and weather conditions permit. Mrs. Bailey (1928) reports them as resident some winters below the 5,000 foot elevation near Cliff, N. Mex., and quotes Stokley Ligon as having observed them on Haut Creek, Socorro County, at 7,500 feet during the winter of 1912-13. Ligon (1927) says that a heavy crop of piñon nuts has in a few instances held them throughout the winter in the Black Range.

Fred Pickens, Deputy State Game Warden, and William Wood, of the United States Forest Service, saw 35 bandtails in the Sandia Mountains near Albuquerque, N. Mex., on December 30, 1940, and on the same day Fred Johnson of the same Service saw fully 100 in a neighboring canyon.

In Texas, Ray Williams, of Alpine, reports, "I have seen them stay in the Chisos Mountains all winter when there is plenty of food," and on March 22, 1941, G. W. Peterson, Deputy State Warden, of Nogales, Ariz., wrote that "band-tailed pigeons stayed with us all winter ... Acorn crop was very good last year."

South of the Mexican border, according to Frederick C. Lincoln, the band-tailed pigeon winters south to Guatemala and Chiapas. A subspecies, Viosca's pigeon (Columba fasciata vioscae), appar- 
ently nonmigratory, is restricted to southern Baja California, and other subspecies occur in Central America.

\section{MIGRATION}

Periods and routes of migration of the bandtails are strongly influenced by availability of food and by weather phenomena, especially temperature and rainfall. Owing to the vast areas of wilderness through which the birds pass, it is difficult to trace their movements, and over much of their range they appear to move in small flocks which often may pass unnoticed.

\section{SPRING}

Search of the literature gives the following "earliest" dates for the appearance of the bandtail in the northerly parts of its range: Colorado, Beulah, May 7; Oregon, Mercer, March 5; Washington, Clallam Bay, April 9; British Columbia, Courtenay, May 31.

Leaving the wintering grounds in west-central and southern California late in winter, the northward-bound pigeons move slowly along the foothills of the Sierras and along the coast mountains. Frequently enormous flocks concentrate in areas of abundant food supply. The date of appearance at various California points varies with the season, but often large flights appear in the live-oak-covered foothills east of Sacramento late in February or early in March. Food supplies to a marked degree seem to control the dates and routes of movement.

Grinnell (1898) observed a large flock that remained until midJune 1895 feeding on acorns near Pasadena, and Van Denburgh (1899) reported the birds as frequently remaining in large bands until mid-May near Palo Alto. Evidently migration is erratic and influenced by a number of factors which in few instances are well understood.

R. J. Little, State Game Warden, reported in 1935 that the pigeons usually arrived in Butte and Sutter Counties, Calif., in February. On February 15 he saw about 4,000 birds near Bangor, and on February 20 about 9,000 arrived at the small mountain uplift known as the Sutter Buttes, where they fed on acorns or on grain stubble in the adjacent valley fields. Nelson Poole, State Warden, described a large flight of pigeons, which late in February and early in March 1935 invaded the oak-covered hills between Sacramento, Folsom, and Auburn. These were feeding as they made their way northward, and soon left the Sacramento area. Near Auburn, however, although the numbers diminished, pigeons were numerous until late in April. Just as the cherry growers began to worry about their presence they suddenly moved on, and no more than normal numbers remained.

In the border States of Arizona, New Mexico, and Texas, it is more difficult to record the spring migration, as in favorable areas some of the birds frequently spend the winter. Ralph Morrow, Deputy State Game Warden, reported his first 1940 bandtail late in February in the Chiricahua Mountains. The usual spring records, however, are of birds observed late in April or early in May. 


\section{AUTUMN}

The autumn migration also is strongly influenced by weather conditions and availability of food. After the major breeding season, pigeons flock together and move about locally following successions of food crops. There is also a definite vertical movement from the mountains to foothill or valley lands. This vertical migration varies greatly in season and in the Sierras of California seems to be stimulated by snow, storm, and cold weather at the higher elevations as well as by local food diminution, sometimes not occurring until December or January.

The latest fall records in the North found in the literature (Bent 1932) are for British Columbia, October 29, and for Washington, October 29. For Oregon, Bent (1932) lists the "latest" record as Newport, October 28. Jewett, in a letter of June 10, 1937, gives the following dates: Harney County, October 19; Multnomah County, October 11; Tillamook County, September 17; and Jackson County, October 6. In 1937 the writer spent the period of September 10 to September 25 in western Washington. During that time moderate concentrations of pigeons were observed feeding in the area immediately adjacent to Puget Sound from Blaine and Sumas in Whatcom County southward to Olympia, and northward to Dungeness in Clallam County. Local game wardens in those areas, however, said that there had been a considerable diminution in the population of the bandtails late in August and in the early days of September. South of Hoquiam and west of Olympia in the area between the Cascades and the ocean almost no pigeons were remaining on September 15 , and local authorities stated that the mass of the population had departed by September 1 to 10 .

The southward migration in Oregon normally begins during the last days of August and is well completed by September 20. Along the coastal mountains definite flyways exist, and from stations on them during the period of major migration it is possible for an observer to note band after band of pigeons passing south from daylight until dark. According to a number of observers, these birds "feed" their way along, the roosting place each evening lying farther south than that of the night before.

A. S. Einarsen, in a letter of October 3,1944 , described a Washington pigeon migration as follows :

On a trip to the State of Washington on September 25, I ran into a migration, and at one point on the Cowlitz River north of Castle Rock, counted 960 birds which came to a point, settling in a few roosting trees and, incidentally, dropping down for a drink of water in a backwater pool before continuing their migration southward almost immediately. In my experience $I$ had never before seen such a steady drift of bandtails at any one point as large or continuous.

And in a brief special report dated March 30, 1943, Einarsen describes another migratory concentration point in Oregon thus:

They may pause for several weeks at some gravel bar or watering hole, and often other flocks join them. These facts have been confirmed by fleld observations at Pigeon Butte in Oregon, 12 miles south of Corvallis and 3 miles west of Bruce station, one of many such points. Here an annual con- 
centration exists from about August 25 to October 10, enlarged by migrations from areas far to the north. Pigeons come into this area to drink at a source of water supply and fly through a pass in great numbers.

From reports of local observers and from personal field observations the writer traced the 1937 migration from Benton and Tillamook Counties southward. From late August to mid-September the bulk of the bandtail population ranged from Corvallis to the vicinity of Coquille and Myrtle Point. The writer followed the flight from September 29 to October 4, and in the northern part of the area found only scattered small groups. In the Myrtle Point-Powers district a light population was found, where 20 days earlier several cooperators had reported enormous numbers. From the Roseburg-Coquille highway in Oregon south to northcentral California stretches a wilderness that is so large and so sparsely traversed with modern highways that proper analysis of the bandtail migration through it is difficult. At numerous places within this great district the south-bound pigeons are reported almost annually as congregating in great numbers. In the 1937 field trip the writer continued southward along the coastal route. At Brookings, Oreg., ranchers along the Chetco River reported on October 4 that pigeons had been very abundant in their stubblefields until the onset of a wind and rain storm on September 29 and 30. Later Einarsen wrote that from October 19 to 23, 1937, there had been a heavy concentration of pigeons feeding on madrona berries in the Applegate section of the Rogue River Valley.

In California it appears that the band-tailed pigeons on the coastal side of the northwest coast mountains congregate in flocks and commence to move south almost concurrently with the beginning of the movement in northwestern Washington and Oregon. State game wardens in Humboldt County, Calif., reported that late in August 1937 there had been a large population of pigeons in the area south of Fortuna and west of Garberville that had moved on southward down the coast prior to the arrival of the northern birds. Captain Harp, State Warden, said that in coastal Humboldt County the autumn withdrawal usually had begun by September 1 and that by mid-October of normal years none of the birds were to be found.

In 1937 the flights of bandtails from Oregon and Washington were apparently reaching northeastern Mendocino, eastern Humboldt, and Trinity Counties by early October, as during that month predatory animal hunters at various localities in the area reported pigeons in great numbers, and by late October considerable flocks were observed in southern Mendocino, Lake, and Napa Counties.

In the Sierras the autumnal flights appear to remain normally at high elevations, hence study of them is difficult. Deer hunters and State game wardens often report moderate concentrations in the area near Mount Shasta and west of Mount Lassen, and at times fairly large feeding concentrations are noted farther south along the range. In many seasons, however, the Sierra pigeon population remains at from 3,000 to 7,000 feet elevations until December.

In 1939 the autumn on the West Coast was very mild, and the 
band-tailed pigeon migration was delayed considerably in comparison with average seasons. Pigeons were present in central Oregon in fairly large numbers all through September and into October, and a few yet remained in early November. Grinnell, Bryant, and Storer (1918) said that "in event of continued favorable weather, the birds will often continue in their summer haunts until October or even November ..." if food is available in these haunts.

Mrs. Bailey (1928) compiled from the reports of several observers a number of autumn records for New Mexico, among which were the following: September 15 and 16, 1914, Upper Blue River Canyon; September 17, 1915, Diamond Creek; and November 10, 1914, 20 miles east of Silver City. W. M. Wilson, of Silver City, informed Lawrence J. Merovka that in 1940 pigeons remained in the area near Tyrone, N. Mex., until November 10, and that others were reported in the Black Range; this, he said, was fully a month later than the normal date of departure.

\section{ROUTES OF MIGRATION}

Except for evidence accumulated through observation of large flocks of band-tailed pigeons, there is little direct information concerning the routes of migration used by these birds. They appear to be very erratic, following those routes that offer satisfactory food for the migrating flocks.

Extensive banding of these birds is needed to furnish more explicit evidence relative to their migrations and to determine definitely the winter range of the pigeons produced in the major breeding areas. Reed Ferris, of Beaver, Oreg., discovered that bandtails are readily trapped when feeding on the ground, and he has banded more pigeons than any one else. Banders in pigeon country should make every effort to mark these birds.

Up to May 1, 1940, only 185 band-tailed pigeons had been banded, and only 5 return records were in the files of the Fish and Wildlife Service. Three of these were of birds that had been banded by Ferris at Beaver, Oreg., late in May 1932. One was shot at China Camp (Calaboose Canyon), Monterey County, Calif., in December 1932; another in the "Monterey Hills" on December 10,1933 ; and the third, 15 miles east of Gonzales, Monterey County, on the same date. A pigeon banded at Carmel, Calif., in July 1937 was shot on December 14, 1937, near Atascadero, Calif., and one banded at the State Game Farm, at Chino, Calif., in June 1937 was found dead near Cucamonga, Calif., during the same month.

\section{VALUE AS A GAME BIRD}

Grinnell (1913) stated that "the value of the band-tailed pigeon as a true game bird is to be conceded without argument. Its pursuit is of a different type from that offered by any other game species." "Stillhunter" (1907), an anonymous writer in southern California, said that the best place for hunting pigeons was near a 
dead tree where the birds alight, and that a .22 or $.25-20$ rifle should be used so that single birds could be procured without scaring the flock; but that for sneaking up on the flocks a "duck gun" was used. Ten pigeons were considered a good day's bag. If the flesh was strong, owing to an acorn diet, soaking it in brine flavored with vinegar or lemon would remove the disagreeable taste. Mrs. Mary Bartol (1940) describes the hunting of bandtails in southern California, noting the long-range shooting and consequent wasting of ammunition and crippling of birds. She mentions also the difference in flavor of the flesh caused by the birds eating different foods.

Since shooting seasons were resumed in 1932 after 20 years of total protection, several changes have occurred in the annual regulations, each tending toward permitting shooting at a period when more pigeons might be killed. The history of these seasons from 1932 to 1945 is abstracted.

Arizona.-1932-1934, December 1-15; 1935-1938, October 16$30 ; 1939$, October $1-15 ; 1940-1941$, September $16-30 ; 1942-1945$, September 16-October 15. $1-30$.

California.-1932-1941, December 1-15; 1942-1945, December

Colorado.-1944-1945, Counties of Archuleta, Dolores, Huerfano, La Plata, Las Animas, Montrose, Montezuma, Ouray, San Juan, San Miguel; and the drainage of the North Fork of the Gunnison River in Delta and Gunnison Counties, September 16-October 15.

New Mexico.-1932-1934, November 1-15; 1935-1939, October $1-15 ; 1940-1941$, September $16-30 ; 1942-1945$, September 16-October 15.

Oregon.-1932-1938, October 16-30; 1939-1941, September 1$15 ; 1942-1945$, September 1-30.

Washington.-1932-1934, October 16-30; 1935-1941, September $16-30 ; 1942-1945$, September 16-October 15.

The very slow rate of increase of this pigeon was apparently sufficient to maintain its population under early conditions, but it is amazing that the species has stood up so well and so long against the combination of modern firearms, good roads into wilderness areas, speedy automobile transportation, and the continued trend toward shooting seasons during the period when the birds are most abundant.

In winter, California is largely responsible for the fate of the bulk of the present band-tailed pigeon population of the Pacific Coast. The first open shooting season after 20 years of protection in that State occurred in 1932, continuing from December 1 for 15 days. The writer was not afield during that period but has received numerous verbal reports from hunters. In the Santa Lucia range of Monterey County, Calif., in the Monterey division of the Los Padres National Forest, there was, on December 1, 1932, a heavy wintering population of pigeons. The road leading to Tassajara Hot Springs resort, at a place close to 5,000 feet elevation, crosses a narrow saddle locally called China Camp, which separates two deep canyons, Miller and Calaboose. Oak and pine trees 
are abundant on the slopes near the summit of the mountains, and a short distance north of the saddle several wide and fairly open oak flats occur. Madrona and manzanita are abundant along the canyons, and water is available in at least one of the canyons.

According to sportsmen, on the first day of the 1932 open season countless pigeons flew across China Camp saddle from Miller to Calaboose Canyons and back again. Hunters quickly congregated and band-tailed pigeon shooting became once again a leading sport. Owing to the roughness of the terrain it was extremely difficult for the game officers properly to patrol the pigeon area and no criticism of them is implied. Certain hunters told the writer of watching gunners who shot all day long, assisting others to obtain their limits, and left piles of birds on the ground.

In 1934 there was again an ample food supply in the area adjacent to China Camp saddle, and a large flight of pigeons gathered there and in the adjacent flats known as Chews Ridge and White Oak Flat. The shooting season opened on December 1, and the writer visited the area on December 7, viewing the flight and methods of hunting and conferring with wardens and hunters. Since the birds flew to and fro continuously, it was practically impossible to estimate the numbers present, but the flight on December 7, after 6 days of shooting, was not unusually large. When there was little shooting at China Camp saddle, the birds flew up and down the two canyons; when numbers of hunters occupied the saddle, the birds, scattered out and flew widely over the mountain-top flats.

On December 9 (Sunday) the writer again went to the shooting area. The entire mountain abounded with hunters, automobiles, and guns. Gunners covered every opening in the forest and shots poured into the pigeon flight from all directions and elevations. At China Camp saddle the picture was not pleasant, as ten men shot where one would have been enough. Sportsmanship was virtually absent. In the continued fusillade of long-range shots, many wounded pigeons plunged to earth or fluttered down to alight in shrubbery or trees. Owing to the steepness of the slopes and their dense vegetation, the loss of birds was very high, possibly as many as five pigeons being lost or mortally wounded for every bird picked up by a hunter.

State game wardens made partial surveys of the kill during this 1934 season, usually counting only the full-limit bags taken off the area. On December 9, however, the writer assisted three State

TABLE 1.--Data on pigeon kill, Tassajara District, Monterey County, Calif., 1934

\begin{tabular}{|c|c|c|c|c|}
\hline Date & Type of count & $\begin{array}{l}\text { Number of } \\
\text { hunters checked }\end{array}$ & $\begin{array}{l}\text { Number of bag } \\
\text { limits checked }\end{array}$ & $\underset{\text { kill }}{\text { Recorded }}$ \\
\hline $\begin{array}{l}\text { Dec. } 1 \ldots \ldots \\
\text { Dec. } 2 \ldots \ldots \\
\text { Dec. } 5 \ldots \\
\text { Dec. } 7 \ldots . \\
\text { Dec. } 8 \ldots \\
\text { Dec. } 9 \ldots\end{array}$ & 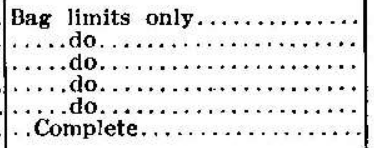 & $\begin{array}{r}185 \\
412 \\
123 \\
60 \\
143 \\
830\end{array}$ & $\begin{array}{r}150 \\
280 \\
60 \\
80 \\
85 \\
445\end{array}$ & $\begin{array}{r}1,500 \\
2,800 \\
600 \\
300 \\
850 \\
6,404\end{array}$ \\
\hline
\end{tabular}

$695766^{\circ}-47-3$ 
game wardens in a complete roadside inspection at the foot of the mountain. The record of kill on the various days is given in table 1 , the figures for December 1 to 8 being generously furnished by the State game wardens covering the district.

In conversation with wardens and several scores of hunters, December 7 to 10,1937 , the writer learned the reactions of the gunners of this district. The vast majority denounced the reckless shooting and the wastage of birds. Numerous hunters expressed the opinion that the band-tailed pigeon could not maintain its existence in the face of such shooting as occurred in the China Camp area in 1932 and 1934 . Fully 20 percent voluntarily declared for regulations to reduce the kill.

Since 1934 there has been no such large concentration of birds at that place. In some seasons there has been a shortage of food, but to the writer it seems that some of the scarcity of birds can be attributed to the terrific shooting of 1932 and 1934. It is for the welfare of the species, therefore, that usually the winter population in California has not concentrated in any such small areas.

The writer observed shooting practices on Whidby Island, in the Snohomish River delta area, and at other places in Washington in 1937. There was no parallel to the California situation, the shooters being widely scattered. The most frequently observed method of shooting, however, left much to be desired in the matter of "sport," as hunters lay in wait and shot at pigeons that perched in the tops of tall Douglas fir snags.

The food of the pigeons during the general period of shooting greatly affects the flavor of the flesh of the birds. In the Puget Sound area during the September open season the major food is peas from the stubblefields, and the birds are said to be of fine flavor. Mrs. Bartol (1940) pointed out the difference in flavor of California birds that fed on piñon nuts from those that ate acorns. By far the majority of pigeons killed in California have fed on acorns or on the fruits of the madrona. Their flesh is flavored by those foods, and old birds are very tough. Entirely too

TAFLE 2-Band-tailed pigeon kill in California, 1934 and 1935: State and thirteen leading counties 1

\begin{tabular}{|c|c|c|}
\hline State and county & $z+261$ & $1935^{3}$ \\
\hline 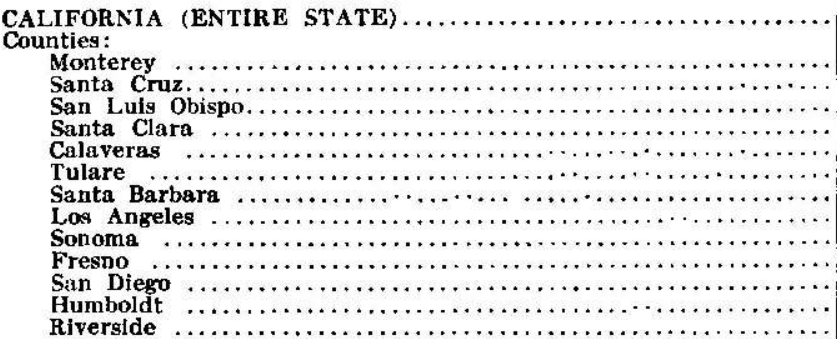 & $\begin{array}{r}51,056 \\
21,961 \\
5,849 \\
1,216 \\
1,075 \\
567 \\
528 \\
520 \\
515 \\
512 \\
506 \\
\ldots \ldots \\
\ldots \ldots\end{array}$ & 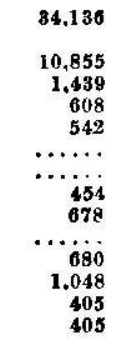 \\
\hline
\end{tabular}

1 Compiled from hunting-license application blanks by the California Division of Fish and Game.

Published in the California Conservationist 1 (8): 8. August 1986.

s Published in the California Conservationist $2(8): 20$. August 1987. 
many of the birds killed are destined ultimately for the garbage can; no specific evidence can be given, but at numerous times the writer has heard statements that could have no other meaning. A relatively small percentage of the gunners hunt pigeons because they like to eat the birds; the majority are in the field for the sport of shooting, the thrill of killing game, and the enjoyment of the high wild country.

In table 2, based on data compiled by the California Division of Fish and Game, is given the band-tailed pigeon kill for the seasons of 1934 and 1935, as reported on applications for hunting licenses for the ensuing year. The table gives the total for the entire State and for each of the 13 leading counties. The figures are conservative, for few hunters will report more than they actually kill and some make no report at all. Table 3, based on data from the same source, shows the 1934 and the 1935 kill of each of California's game birds.

TABte 3.-Game bird kill in California, 1934 and $1985^{1}$

\begin{tabular}{|c|c|c|}
\hline Game bird & 1934 & 1935 \\
\hline 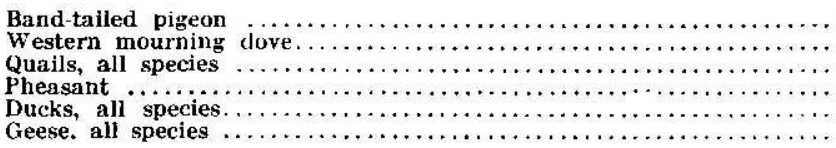 & $\begin{array}{r}51,056 \\
580,110 \\
560,481 \\
25,226 \\
380,217 \\
40.278\end{array}$ & $\begin{array}{r}34,136 \\
539,722 \\
916,589 \\
40,616 \\
301,882 \\
85,096\end{array}$ \\
\hline
\end{tabular}

\footnotetext{
${ }^{1}$ Compiled from hunting-license application blanks by the California Division of Fish and Game; published in the California Conservationist $2(8): 20$. August 1937.
}

\section{Writing of Pigeon Butte, near Corvallis, Oreg., Einarsen says:}

For years this pass has been popular with hunters. Because of the terrain and the usual eagerness of the hunter, most of the shots are at long distances, which results in a crippling loss averaging more than 60 percent of the pigeons bagged. When the number of birds killed (at each pass) is more than 600 , as in $\mathbf{1 9 4 2}$ at this pass, the seriousness of the slaughter can be recognized.

The band-talled pigeon will never have wide abundance. It is hunted on uneven ground, where a high percentage of crippled birds are lost and little effort is made to recover them. Five months after the season it was still possible to pick up birds which had died of injuries in large numbers around Pigeon Butte.

Far too few hunters know that band-tailed pigeons decoy well, and in many localities far better sport could thus be obtained with an accompanying great reduction in the number of crippled or dead birds lost. Decoying the bandtails into forest openings or fields is far preferable to shooting them at waterholes or gravel bars, pot-shooting perched birds out of dead snags, or to the average mountain-pass shooting in rough, brushy terrain.

\section{PRESENT STATUS}

Under conditions that prevailed between 1932 and 1942 it appeared that the band-tailed pigeon held its own under the 15-day 
shooting season and low (10-bird) possession bag limit; there are those who state emphatically that in certain localities it was not maintaining itself, but was slowly decreasing. It is too soon to analyze the effect of the 30-day shooting season established in 1942, as wartime conditions of ammunition shortage and gasoline and tire rationing markedly affected pigeon shooting. Where numbers of the birds are to be found not far from hunting centers there may have been some reduction, but in other districts pigeon concentrations occur only in wilderness areas where during the war period few hunters could reach them.

In several States where there is an open season, it is set at a period when many of the birds have already moved southward, and there has been local clamor for a change of the season to coincide with the presence of peak populations. Such requests for changes in shooting seasons should be closely scrutinized for, if granted, they may lead to great increases in the kill in States in which the pigeon population is too low. Seasons of good shooting result in a great increase in the number of shooters afield; reports of poor shooting soon result in decreased hunting.

Earlier summaries of the status of the band-tailed pigeon are those of Chambers (1912), Grinnell (1913), and Taylor (1924). Owing to the extreme erratic nature of the species, accurate appraisal of its status over all the range is extremely difficult. The writer's own observations and reports of others are summarized for their interest in this connection.

A. S. Einarsen in a report, dated January 6, 1936, stated that "regardless of what may be said to the contrary, the population of band-tailed pigeons in the Fraser Valley, the Puget Sound country, the islands of Puget Sound, the river valleys west of the Cascade Mountains in Washington State, and in the favored nesting areas west of the Cascades in Oregon shows a tremendous decrease from that of the 1934 season..." Pearse (1940) said that bandtails were reduced to a precarious state on Vancouver Island and blamed overshooting in the winter habitat. Miller, Lumley, and Hall (1935), writing of San Juan in Puget Sound, state that numbers are decreasing rapidly.

Einarsen, in a letter of October 3, 1944, reported that "the migration in Oregon, generally speaking, has not been as great as in previous years, but there have been a few birds passing through throughout the entire month."

Field investigations in the Puget Sound area between September 13 and 25, 1937, indicated that the population of bandtails was from 50 percent to less than 10 percent of what it had been at the same date in 1936. This means little, however, in the absence of correlated data on weather and food conditions for the period concerned. In Whatcom County the 1936 population was reported as heavy, that of the spring of 1937 as normal, and that of the autumn of 1937 as very light. Snohomish County estimates placed the 1937 population at about 10 percent of that of 1936 . In Skagit County, although scattered groups of birds were present, no pigeon concentrations were observed in September 1937.

San Juan reports indicated a normal 1937 season, except that 
the autumn migration had occurred earlier than usual. Similar reports were obtained from Thurston, Grays Harbor, and Mason Counties. Pacific County reported an increased population in the spring of 1937 and an early autumn departure. Pierce County had a very large spring population, which dispersed to nest and did not reassemble. Lewis County experienced a marked increase during the 10 years previous. In Clallam County there were large spring concentrations during 1935, 1936, and 1937, and in some areas an abundant summer population also. Officials agreed that there was an increase in the area known as the Black Hills district near Elma, Shelton, and Olympia. Game protectors in all the counties named (except two) reported annually increasing shooting.

On September 27, 1937, United States Game Management Agent Gerow said that although numerous complaints of crop depredations had been received, the consensus of opinion was that pigeons were decreasing in numbers in Oregon. Alex Walker, of Beaver, Oreg., reported on September 30, 1937, that at best the pigeon population in Tillamook County was standing still and on March 30,1940 , he was of the opinion that the birds were definitely decreasing. Coincident with the late 1939 autumn migration in Oregon, a considerable increase in hunting was reported in some parts of the State.

Allen C. Oberle, of LaVerne, Calif., wrote on February 15, 1935, that in the San Dimas district of Los Angeles County there was a flock of about 350 pigeons where in 1926 there had been only three pairs. Lawrence W. Saylor (formerly with the Fish and Wildlife Service) wrote on January 15, 1940, that bandtails did not become at all common in the Ben Lomond section of the Santa Cruz Mountains of California until about 1932, when in a few seasons the flocks increased from a dozen birds to a hundred or more. Warden C. E. Holladay, of San Jose, Calif., said in 1934 that the pigeon population of Santa Clara County had doubled in 6 years.

From these and numerous recent reports it appears that the breeding population of band-tailed pigeons in California is holding its own in all sections; each year there are reports of pigeons nesting in areas where they had not been known to nest for years, and these seem to indicate that the California breeding population is slowly increasing and extending its range.

In Colorado, Bergtold (1928) called the bandtail an infrequent summer resident, and in the Denver area Niedrach (Niedrach and Rockwell 1929) reported the birds as regular summer residents in small numbers. Studies of the past two or three seasons substantiate a statement by $\mathbf{E}$. R. Kalmbach to the effect that these birds seem to have decreased in numbers in northern Colorado, for few birds have been observed in the northern half of the State. On the other hand, in the southern part of the State and in a few more northerly localities, the birds seem slowly to have increased. Frank F.' Poley, United States Game Management Agent, believes that there has been a constant but small annual increase for the past 10 years, especially in southern Colorado; 
and Barry C. Park, of the United States Forest Service, says that the pigeon in Colorado is increasing slowly but constantly and is extending its range each year.

Inquiry among game officials and sportsmen in Arizona from 1938 to 1941 leads the writer to believe that the pigeon population of that State is slowly increasing. Recent seasons of drought caused food failure in many parts of Arizona, and this resulted in very erratic movements of the birds. Very few birds are shot in this State as the season opens after the bulk of the pigeons of the southern part of Arizona have moved into Mexico, and the birds are widely scattered.

Ligon (1927) said that the bandtails did not appear to increase in New Mexico but remained at about a constant level, and that the population was insufficient to justify an open shooting season. No recent general statement is available, but the reports from various localities, in New Mexico indicate that the bandtail there, as in Arizona, may locally be slowly increasing.

From Texas, Ray Williams, of Alpine, wrote in November 1940: "For 25 years I have observed them in this territory and I do not see any increase in their numbers. They will never be too plentiful ... They ... just about hold their own."

Winter populations are most difficult to appraise owing to the wandering habits of the birds and to the wide range of country in which concentrations may occur. No recent information from wintering range indicates a decrease, nor is there any reliable evidence of any marked increase.

Considering actual pigeon populations alone, without reference to any other phase, it is felt that only in the Pacific Coast States are there sufficient numbers of birds to justify hunting. In Arizona, New Mexico, Colorado, Texas, and Utah, the habitats and habits of the birds may be such that few birds are killed and little damage results from open shooting; yet there is danger of again decimating the species. Shooting must be rigidly controlled. Local increases may easily be decimated by concentrated shooting in more southerly migratory or wintering areas.

It is of the utmost importance that Federal and State wildlife officials proceed with caution in liberalizing shooting privileges on this species in any part of its range. It is even more important that they carefully note the year to year status of the species over its entire range so that the need for reduction in numbers made necessary by local conditions may be anticipated and hunting control measures applied in sufficient time to prevent gross destruction that would require a total closing of the season such as was necessary in 1913.

\section{MANAGEMENT POSSIBILITIES}

It is inevitable that during a study such as this many questions that relate directly to management of the species should be raised. From a few sources have come direct inquiries concerning methods that might permit development of a sufficient population of band-tailed pigeons so that more shooting might be allowed. 
Most important of all management practices must be the careful guarding of the species through continued stringent protection, with short shooting seasons and small bag limits. Crop depredations must be controlled or prevented with the minimum destruction of the pigeons. The species cannot withstand liberalized shooting in more than a few districts, and because of its restricted range, excessive liberalization at any point is undesir able.

Through cooperation of the local agencies concerned, most often the United States Forest Service and the State Game Departments, shooting should not be permitted at all in places where large concentrations of the birds are exposed to highly destructive hunting, examples of which have been mentioned (p. 31).

Normally, the bandtail is a native of the primitive forest and rough, wild country, usually at fairly high elevations. Management practices that in any manner assist in maintaining primitive areas in this country aid the bandtail; among these are fire protection, erosion control, restriction of human intrusion, and reforestation.

Few birds are controlled so completely by available food supplies as is the bandtail. Hence, management of food supplies might be expected to form part of any management program. Full study of the food habits of the bird, however, fails to elicit optimism as to the possibilities in that direction.

If any area is to attract and hold a winter population of bandtails, it must afford a bountiful supply of acorns or piñon nuts. Although the pigeons feed upon wild fruits and berries, in part, throughout the winter, mast is necessary as winter food. Hence any program looking toward increasing the winter population of pigeons must include increases in the mast supply.

During summer the food of the bandtail includes a wide range of wild and cultivated fruits and in some districts, acorns and grains. The use of cultivated fruits and grains may be largely eliminated from consideration as a practice intended to increase pigeon populations, for, except in local areas, an increase in planting of these would entail reduction in the forest or would increase the depredation problem.

In brief, it seems that only three practices are of real value in the management of the band-tailed pigeon: conservation of our present population; preservation of primitive and marginal wildernesses and woodland to offer habitat; and forestry, including fire protection and reforestation of already denuded lands, using wherever practicable species of plants that are of known value as bandtail foods. There are strong possibilities in the planting of wild fruits, such as mulberry, in high mountain park areas where these trees might thrive and where food is now scarce.

\section{AGRICULTURAL RELATIONSHIPS}

\section{DEPREDATIONS}

Depredations on agricultural crops by band-tailed pigeons although sporadic may be serious. They are generally local and vary 
greatly from season to season. They sometimes involve numbers of birds so large as to be amazing, and again may concern only a few pairs. Their occurrence is so erratic as to be impossible to forecast, although in some areas slight to moderate damage may be done annually. The supply of natural wild foods is a determining factor in the occurrence of crop damage because of its effects on both pigeon concentrations and routes of migration. With natural foods plentiful in the mountains and wilderness there is less necessity for the pigeons to feed extensively on cultivated crops.

Many of the complaints against band-tailed pigeons come from ranchers whose production is relatively small, or they may concern only the loss of garden or orchard crops destined for home consumption. Noticeable attack on the products of large-scale farming operations is infrequent. Depredations on small acreages are more quickly noticed, have more vital importance, and concern a far greater number of individuals. Very frequently even a moderate loss in a cash crop like cherries may be keenly felt by the farmer concerned, and if the loss is heavy, it may mean financial disaster even though only a few trees are damaged. Even so, far too great a percentage of the complaints against the pigeons, as against other game birds, upon close analysis, are found to be unjustified. In many instances the desire to shoot pigeons for food will be found to be the underlying motive for the complaint.

In the literature are a number of records of band-tailed pigeons feeding on agricultural crops or their residues but only a few can be mentioned here. Fisher (1893) reported bandtails foraging in barley stubble in 1891, and Gilman (1903) noted large flocks of them in barley stubble in Riverside County, Calif., in March 1901. Grinnell (1913) mentions good-sized flocks on newly sown barley fields near Palo Alto in January 1901 and near Santa Monica in February and March of that year, and Barnes (1916) discusses alleged damage to grain. Anonymous news notes in 1924 and 1930 reported damage to cherries and grapes. Burtch (1930) discussed damage to grapes, and McAtee (1932) abstracted complaints against the species.

Taverner (1926) writes that "they are especially partial to peas and are said to pull up the sprouting seeds . . . As they are large birds, each one intent on filling a capacious crop, their power for damage is not small. In the autumn they alight upon the stooked grain and may take a considerable toll of it."

Grinnell and Storer (1924) describe bandtails feeding near the edge of a newly planted grainfield on the floor of Yosemite Valley in April 1916. Grinnell, Bryant, and Storer (1918) cite a single bird taken near Crescent City, Calif., on May 15, 1916, whose crop contained 509 kernels of barley, 23 of oats, 6 of corn, and fragments of acorn. Jewett reported depredations on newly planted fields of oats in Tillamook County, Oreg. Grinnell, Dixon, and Linsdale (1930) record a few bandtails coming in pairs or in small groups to cherry trees near Manton, Tehama County, Calif. (June 4, 1936). Kobbe (1900) said that they fed in wheatfields in Pacific County, Wash. 
Munro (1924) reported on an investigation of band-tailed pigeon damage in British Columbia as follows:

On June 9, 1923, I had occasion to investigate a report that band-tailed pigeons were causing damage to sprouted wheat on a small bush farm in the Sooke district. The farm in question was found to include a portion of a large beaver meadow-one of the few open areas in this heavily wooded region-the balance comprising rough timbered hillside, and a wooded ravine through which flows a small stream. About eight acres of the meadow had been seeded to wheat and oats by hand and as always is the case with this method of sowing, a large percentage of the seed was on the surface. This exposed seed had germinated.

Pigeons commenced feeding on the wheat fleld shortly after my arrival, so, in order to study them at close quarters-for they are invariably wild when in the open-I made a careful stalk through the wooded ravine and reached, unobserved, a suitable hiding place at the edge of the field. From this position it was seen that $\mathbf{5 3}$ pigeons were feeding. Usually in flocks of this size small detachments from the rear keep flying over the main flock to alight in front of the foremost birds, but on this particular day the birds kept their formation - an undulating blue ribbon - and slowly moved across the field in my direction until a scant 60 yards distant, when they suddenly arose, circled several times, and then dropped on another part of the field-there to spread out immediately and commence feeding as before. From the several dead trees amongst the green timber behind me came other birds, singly as a rule, and joined the feeding band. Close observation with binbculars showed that only surface seed was being taken, the young plants from buried seed were not pulled up.

\section{Mrs. Florence Merriam Bailey (1928) writes:}

On the west side of Moreno Valley, on July 4, 1919, Mr. S. E. Piper discovered that two or three thousand Pigeons had congregated along the borders of a deep cove. He was attracted to the place by heavy shooting on the part of the ranchmen-mainly foreigners who said that the birds destroyed their young grain, especially barley. On examining several areas from which the birds rose, Mr. Piper could find no indication that they were either digging or pulling the young grain; and barley found in the gizzard of one was old stained grain evidently gathered from the surface or about old stack or shock stands. It was evident that the hunters were seeking justification for shooting them, though several averred that they found them unfit to eat.

The following accounts of band-tailed pigeon depredations were reported by ranchers, State game wardens, United States game management agents and other representatives of the Fish and Wildlife Service (formerly the Bureau of Biological Survey), and other persons. These reports include in some instances not only the original complaint but also a statement of the results of investigations by officials. A few of them have appeared in print, but most of them have never before been published.

\section{CHERRIES, GRAPES, AND PRUNES}

On August 20, 1920, E. R. Kalmbach, of the Bureau of Biological Survey (now the Fish and Wildlife Service), recorded that ranchers near Lookingglass, Oreg., reported severe damage to cherries by band-tailed pigeons.

Forest Supervisor Blair, writing from Glenwood Springs, Colo., May 29, 1920, transmitted reports of pigeon damage to cherries on several ranches in that area. One rancher who complained of very severe losses said that scarecrows were a failure and that 
men without guns could not keep the birds out. Mr. Blair quoted several other small ranchers as saying that the tops of the cherry trees were completely stripped of fruit.

On June 27, 1921, W. F. Kubichek, of the then Bureau of Biological Survey, made a study of the situation as reported in 1920 . He described the area concerned as a narrow belt between the Colorado River and the mountains beginning 10 miles east of the town and widening to the west. After a thorough inspection $\mathrm{Ku}$ bichek reported (unpublished manuscript) that bandtails were seriously destructive in only a few orchards and in general were doing less damage than were other species of birds. In an orchard where severe damage had been reported he found a few pigeons feeding and was greatly surprised at their fearlessness and the extreme difficulty he had in driving them from the trees. His conclusions were that in most instances it was the size and conspicuousness of the pigeons that alarmed the owners and that actual damage by the birds was not great.

In May 1921, Charles C. Sperry, of the Biological Survey, investigated complaints of depredations on fruits by birds in Oregon. In his report (unpublished manuscript) several complaints against bandtails are included. In Lane County, Oreg., three fruit growers claimed measurable loss of cherries through damage by pigeons, and in Douglas County, Oreg., two out of four growers interviewed made the same report. From Multnomah, Benton, Linn, Marion, Polk, Yamhill, Clackamas, Columbia, Washington, Wasco, Umatilla, and Jackson Counties no reports of damages were received.

On June 25, 1923, Ray C. Steele, United States Game Warden, wrote of a visit to a cherry orchard near Riddle, Oreg. Pigeons were abundant, some trees being literally filled with them. They were very shy and flew when approached, preventing the collecting of specimens. The ground was covered with cherries, about 10 percent of them showing bill marks, the remainder having been knocked from the trees as the birds alighted or fed in the branches.

On July 20, 1923, B. R. Britton, United States Game Warden, reported damage to cherries in the Teseque Valley on the western slopes of the Sangre de Cristo Mountains of New Mexico. On July 12 on the Williams ranch, he saw trees that appeared bluish because of the many pigeons in them. On some trees the fruit was completely devoured, on others the tops were stripped. On this 84-acre ranch Britton estimated a loss of 20 to 30 percent of the cherry crop. Thirty trees near the margin were completely stripped. One bird was watched as it picked 20 cherries and dropped about one-third of them as it attempted to swallow them.

On March 7, 1924, a fruit grower of Paradise, Calif., wrote to the Biological Survey regarding pigeon depredations: "My cherry season lasts six or seven weeks ... Last season I spent forty dollars for ammunition and had to hire a guard for four weeks; at that I lost over 1,500 pounds of cherries." Another orchardist of Paradise, also in 1924, reported: "For the last three years our cherry crop in this section has been destroyed by wild pigeons ... 
I speak for about 20 growers who estimate their losses at from one-fifth to three-fourths of the crop." In a letter of June 24, 1925, an orchardist of Fortuna, Calif., said that pigeons had taken between 1 and $11 / 4$ tons of cherries that year.

In a letter of June 19, 1925, George Tonkin, United States Game Warden, reported several complaints against pigeons. The following comments are abstracted from his letter:

In the Paradise district, 80 miles almost due north of Sacramento, there are many pigeons. There is said to be a roost and breeding ground in the vicinity of this district and the pigeons are there nearly the entire year. I found only three farmers in this district who complained about the birds to any extent. ... These ranchers have frightened the birds away even though they had, up to the time of my visit, been unable to get any oldfashioned black powder. One of them told me that a bullet from his 30-30 rifle fired across the orchards had a very good effect.

At another nearby ranch Tonkin found pigeons feeding in cherry trees close to the ranch house, and it was apparent no effort had been made to frighten them away. Five shots from his revolver drove fully 75 birds from the orchard. Upon investigating the complaint of a rancher near Inwood, Calif., in June 1925, Tonkin found the small cherry orchard in a wooded section completely surrounded by heavy forests. Near Mount Shasta a tenant reported pigeons attacking his strawberries. Here Tonkin saw many pigeons flying about, but as the ranch chickens had free access to the strawberry patch, he did not feel that the pigeons should be held responsible for the alleged damage.

An orchardist of Dunsmuir, Calif., on May 7, 1926, wrote of the bandtails: "They are in this section by the thousands, and you can stand and shoot and they will fly away a few feet and circle right back. We have lost our entire crop of cherries but about 60 pounds out of 1,000 this year."

On June 21, 1928, United States Game Warden Tonkin reported his investigations of several pigeon complaints. Near Garberville, Mendocino County, Calif., he inspected a small orchard of fine cherries completely surrounded by heavy redwood forests. The rancher was shooting at, and killing a few of the pigeons to protect the crop. Near Fortuna, Scotia, and Carlotta, in Humboldt County, Tonkin visited other similar orchards. In one of them the rancher or his sons maintained constant patrol with a .410 gage shotgun. Pigeons were numerous; wild berry patches in the timber attracted large numbers, which at times invaded the cherry orchards.

Recommending that an open season on band-tailed pigeons be permitted in California, Tonkin said: "It seems reasonable to believe that the wild band-tailed pigeons have been (and are now) a serious menace to the cherry and grain crops in Humboldt County. Under present conditions I do not believe that the killing of wild pigeons in the cherry orchards can be stopped so long as the farmers feel that it is impossible to drive them out by other means."

A fruit grower of Gilroy, Calif., wrote on August 27, 1930: "This spring they (the bandtails) came in here by the hundreds 
and fed on green prunes, stripping some trees before we realized what they were doing. The State game warden estimated that in 6 miles along the foothills they did damage amounting to from $\$ 2,000$ to $\$ 2,500$ to the prune orchards."

The superintendent of a ranch near Arvin, Kern County, Calif., reported on March 18, 1930, that wild pigeons were damaging the extensive vineyards on the ranch. The local State game warden, county agricultural agents, and Biological Survey officials were notified. In 1929, a heavy tonnage of grapes had not been harvested. These had dried to raisins on the vines, and in March were on the ground as the result both of natural fall and of the seasonal pruning of the vines. On March 21, 1930, deciduous fruit trees on the property were in full blossom and the grapevines had already put out tender shoots that were from 2 to 4 inches long; these shoots carry both the leaf and the blossom for the current season. The pigeons frequenting the vineyards were so numerous as to arouse great interest. Capt. E. P. Brownlow and Lester Arnold, Warden, of the California Division of Fish and Game, made a detailed study of the flight and estimated that 200,000 pigeons were involved. Investigation disclosed that the birds roosted on Bear Mountain, some 6 miles to the eastward, and that the acorns and other wild foods in the foothill area had been almost entirely cleaned up. In the vineyard the enormous flocks of bandtails would alight on the trellised grapevines, then drop to the ground to feed on the waste raisins; in doing this they broke off the tender new growth carrying the current season's crop. In the nearby deciduous fruit trees they alighted at times in such numbers as to break branches and to knock off the blossoms. The defense measures undertaken are discussed under Methods of Crop Protection (p. 46). The situation was described by Burtch (1930). The depredations of the pigeons continued from March 18 to and including April 2. Officials of the ranch estimated the loss of Malaga grapes alone at 500 pounds a day, and the loss of peaches and plums at 300 pounds a day. They estimated a total loss of $\$ 5,000$ for the grapes and $\$ 1,000$ for peaches and plums. In addition, it was said the owners of the ranch and the State Division of Fish and Game together expended about $\$ 2,000$ in attempting to drive the pigeons from the vineyards.

County Game Warden Fredericksen, of Gilroy, Calif., reported that during May 1934 five prune orchards near Gilroy were damaged. In one of these the pigeons flew across nearly 2 miles of almost solid prune orchard and virtually destroyed the crop in a 10-acre block of sugar prunes.

For many years pigeons have attacked cherry crops in the vicinity of Mountain Park, Otero County, N. Mex., and during June and July 1939 J. S. Ligon, of the Fish and Wildlife Service, investigated conditions there. He reported that the pigeons were not so abundant as during some other years, but that damage was even heavier than usual owing apparently to a food scarcity in the Sacramento Mountains. Because of drought, less grain had been produced in the lower altitudes, and the pigeons concentrated on 
the cherries, which, in that locality, ripen before most of the natural wild foods.

At intervals late in June and early July of 1940 and 1941, J. C. Knox, United States Game Management Agent, of Albuquerque, inspected the Mountain Park cherry orchards. He reported damage to about 20 orchards, totaling about 2,500 trees, scattered about in narrow mountain canyons. During his 1940 investigations he estimated that he did not see more than 250 pigeons, but "when 50 to 100 of them alight in one tree at a time, they either eat or bruise all the cherries in a very short time, and some of these cherries sell for 25 to 30 cents a pound." In 1941 there was a great increase in the number of pigeons attacking the cherry orchards. Knox estimated that there were 1,000 bandtails.

\section{GRAIN CROPS}

In August 1921, Webb Toms, Assistant Warden, of the California Division of Fish and Game, reported depredations by bandtailed pigeons on wheat in the San Luis Rey Valley of San Diego County. One rancher claimed that wheat enough to fill 20 sacks had been taken. Damage was inflicted only while the wheat was in the shock, and pigeons covered the shocks so densely as to break off many of the heads which dropped to the ground and were wasted. In contrast, 16 years later (1937), E. H. Glidden, State Game Warden, of San Diego, Calif., said that "depredations by wild pigeons are unknown here."

On July 22, 1923, B. R. Britton, United States Game Warden, investigated a complaint of pigeon damage near the top of the White Mountains of New Mexico. Thirty acres of winter wheat were ready to harvest. The surrounding country was in a wild state, covered with scrub oak and scattered pines; the elevation was about 8,000 feet. Britton estimated a 5-percent loss of the grain, mostly in small patches near the edges of the field close to large pine trees. In these places the stalks were beaten down, the heads broken away, and the grain stripped off. The owner later said that as soon as the grain was shocked the bandtails came in even greater numbers and stripped the shocks.

On September 26, 1924, an agriculturist of Sumas, Wash., reported that he had 7 acres of fall wheat planted, that the pigeons had been eating there since planting time, and that they were even pulling up sprouted plants.

During April 1932, the writer recorded two instances in which migrating flocks of bandtails crossing the Sacramento Valley, Calif., alighted in a newly seeded rice field and ate the broadcast seed until driven out. In January 1934, a large flight of pigeons invaded the Pacheco Pass district of California. Ranches there are more or less marginal in nature, and complaints of severe damage to grain were received. Permits for killing the pigeons committing the depredations were issued, and local wardens reported 3,300 pigeons killed, a far greater number than was justified by the damage.

Frank Poley, United States Game Management Agent, on Sep- 
tember 26, 1941, investigated complaints of depredations on wheat in the Sanborn Park area near Norwood, Colo. On one ranch he estimated a loss of about one-third of the shocked wheat. Similar losses were noted on several adjacent ranches.

From April 28 to May 15, 1925, Ira N. Gabrielson investigated alleged depredations by band-tailed pigeons in two Washington Counties, San Juan Island and the mainland areas in Whatcom County. Both areas were extensive pea-growing districts, totaling from three to four thousand acres. Of the Sumas district of Whatcom County, Gabrielson wrote: "Whatever the condition may have been at other seasons, there was no damage at all in this district in the spring of 1925 . There were no pigeons in the district nor had there been any up to the date of my departure (May 11). Testimony agreed that when the pigeons came in, they ate all the peas left on top of the ground. The claim was made that these peas on top of the ground would grow if left there. Most of the farmers refuted this, saying that the peas on top of the ground, while they might sprout, would never make good plants." During his study Gabrielson observed a field in which there were many peas on top of the ground; because of favorable weather, these had sprouted, but on the day of his inspection the sun shone brightly and the ends of the sprouts were blackening and shriveling.

Residents of the Sumas area told Gabrielson that pigeons had been exceedingly abundant in the spring of 1924, and that this had led to numerous complaints.

On the islands Gabrielson found a more difficult situation. Most of the peas were grown on San Juan Isiand, and only a few on Orcas and Lopez Islands. The industry there had developed rapidly after its start in 1922, and in 1925, 1,000 acres of peas were being grown for the cannery. The soil was largely moisture-retaining, stiff clay, hence hard to work and cloddy, and the drills left more peas exposed than on lighter soils. This condition led to the numerous complaints against pigeons.

It was the practice of most of the farmers to run a clod-masher over the fields after seeding was completed. The only loss attributable to the pigeons was the eating of peas from among the clods in the interval between seeding and clod-mashing. Farmers almost unanimously agreed that peas left on top after the masher passed were valueless.

Farmers on those islands who grew grain or peas for seed told Gabrielson that the bandtails did considerable damage at harvest time through alighting on the shocks and eating all the seed they could reach.

An orchardist of Sequim, Wash., on April 17, 1935, said that in 1933 he had suffered a total loss of five acres of peas and that he had a thin stand on the remainder of his planting; also that many bandtails were present at the time of his reporting and severe damage would probably occur. When a Biological Survey investigator inspected the property the pigeons had already departed, but there was evidence that large patches of peas had been cleaned up. The orchardist told the investigator that he grew peas for seed and that the greatest damage was inflicted on the ripening 
seed crop in August when the birds alighted on shocks, bent the curing plants, and shelled them onto the ground.

S. J. Handron, State Game Protector, of Hoquiam, Wash., reported on May 24, 1937, that between two and three thousand pigeons were feeding on pea plantings near Elma, Wash.; and on September 21, 1937, Fred Rice, State Game Protector, of Port Angeles, Wash., told the writer that for the past 3 years the spring concentration of bandtails had been exceptionally heavy and that severe damage to oats and peas had been sustained.

\section{WALNUTS}

In February and March 1932, a large concentration of pigeons near Exeter, Calif., caused unusual damage. The birds gathered at dusk in an English walnut grove in such numbers as to break branches from the trees. By counting pigeons in several of the trees Capt. O. P. Brownlow, in charge of the State Game Patrol in that area, estimated that at one time there were in excess of 25,000 bandtails in that grove.

\section{METHODS OF CROP PROTECTION}

Methods of effectively and economically protecting crops from damage by band-tailed pigeons have been more or less extensively studied by certain farmers and by conservation officials. In the reports of field men of the Fish and Wildlife Service are numerous notes on this phase of the pigeon problem.

Gabrielson in his 1925 report wrote of a rancher near Bellingham, Wash.:

He stated that the issuing of permits would not help any as the average farmer did not have the time to stand around and shoot these birds, and that they could not kill enough of them to make any difference. His belief was that some sort of frightening device would be of much greater value. He found that firing a gun from his front porch frightened the pigeons for an hour or two. He started in with a 12-gage shotgun ... [he] found the 22 rifle just as effective.

In 1926, George Tonkin, United States Game Warden, reported on a method of driving pigeons from cherry orchards:

On the morning of May 16 I arrived at an orchard at Paradise [Calle.] before 5:30 a. m. I had a 10-gage shotgun and some shells loaded with 8 drams of black powder, known as the yacht cannon load. I demonstrated to several ranchers that day that a shot fired from this gun, loaded with black powder and without shot, would frighten the pigeons from their orchards and from the roosting places in the oak groves for a distance of one-third to one-half mile from the place where the gun was fired. But the birds either returned in a short time or another flock took their place, probably the latter case. At any rate, it is necessary for a rancher to keep a guard in his orchard from daylight until dark. On some days the pigeons appear to have left the country; perhaps on the following day a flock will visit the orchard every few minutes. It is a great hardship for farmers who have a large orchard some distance from their residence, as a few minutes' absence from the orchard may mean the stripping of cherries from several trees.

B. R. Britton, United States Game Warden, thus described his attempts at protecting grainfields from pigeons in the Teseque Valley, near Santa Fe, N. Mex., in 1923:

I purchased some black powder shells and returned to the Williams farm, arriving about 2:30 p. m. I took the shotgun shells and cut the shot 
portion of them away, and began patrolling the orchard, firing on the pigeons whenever I was close to them, but found this had little effect. Continuous patrol by myself and hired men had the effect of keeping the birds moving. At daylight on Friday morning I found the birds roosting in the cottonwoods adjoining the orchard, and slipping under these trees I fired blank charges up through them. This was continued all day, and $I$ found that when I could get close enough to the trees in which the birds were roosting or feeding to get the smoke and report of the gun practically among them that it had a terrifying effect. I found that the pigeons would avoid a tree in which they had been disturbed in this manner.

Constant patrol was maintained from $5 \mathrm{a} . \mathrm{m}$. to $7 \mathrm{p} . \mathrm{m}$., someone being in the orchard all the time. I myself gave parlicular attention to the resting places of the birds along the edge of the orchard. Part of the time I used a revolver and part of the time a 30-40 rifle, simply discharging them into the air. I found that the report of the rifle or revolver had a more terrifying effect on the birds owing possibly to the sharper report. I also tried fluting or cutting the revolver bullets, which resulted in a screeching sound as they passed through the air. By Monday the birds had practically deserted the cottonwood trees adjacent to the orchard as resting places (except in the very early morning) and rested in the scrub cedar and piñon trees on the hillsides. From there they were routed by firing the rifle into the dry hillside in the vicinity of the roosting trees; this caused a cloud of dust which kept the birds moving. The birds then moved into a canyon behind a hill, and I followed them there and finally succeeded in driving them out of there. By Wednesday morning there apparently remained only about $\mathbf{3 0}$ or 40 birds and these were very wild, fiying high, and if they dropped into the orchard, would rise on the approach of any one. On Wednesday afternoon there was a violent thunder storm accompanied by a high wind, and about $5 \mathrm{p} . \mathrm{m}$. a flock of about 200 plgeons appeared and were persistent in settling in the orchard, acting in the same manner as those found in the orchard at first, having to be driven from the trees in which they settled to feed. I might state that the orchard as viewed from the hillsides appeared like the madrone woods in California, which were favorite feeding places for the wild plgeons; and in my opinion it was this bright coloring that attracted passing birds. Thursday morning there appeared only the remnants of the flocks that were at first present, the flock of birds that had appeared on Wednesday evening apparently having passed on.

In July 1937, the writer was collecting specimens of bandtails in the mountains near Santa Cruz, Calif. One mountain ranch visited contained about 20 fine trees of sweet cherries, all loaded with a heavy crop of good fruit. Among the birds, of six species, noted feeding on the cherries were approximately 30 to 50 pigeons. In one instance about a half dozen of these birds alighted in the top of a tree on which two fruit pickers on short ladders were working. They fed until one of the pickers, after drumming on his pail and velling, descended to the ground and threw clods at them. Shooting incident to collecting specimens continued intermittently for an hour, and the pigeons at no time retreated farther than the tops of some tall sequoias and other conifers adjacent to the cleared farm land.

James A. Blair, Forest Supervisor, at Glenwood Springs, Colo., writing on May 29, 1920, quoted a rancher in that area as having tested the effectiveness of scarecrows in preventing damage by pigeons. The rancher said that his cherry pickers tried to frighten away the pigeons, but that no method except the use of a shotgun would cause them to do more than circle to another part of the orchard.

In attempts to frighten away the enormous flocks of pigeons that were damaging the vineyard on the ranch in Kern County, Calif., 
in 1930 , previously mentioned (p. 42), various methods were tested. Among these was that of trying to feed the pigeons in the mountains near their roosting grounds. There 1,000 pounds of barley and 500 pounds of raisins were scattered. The pigeons are said to have taken this food, but they were so numerous as to make the method ineffective. An airplane was then used in an attempt to drive the birds from the vineyard, but without success. The California Division of Fish and Game and the owners of the ranch cooperated in hiring 16 men to patrol the vineyards and in furnishing the necessary ammunition. After a week's trial, the flocks appeared to be little diminished in numbers and the damage was said to be increasing, owing to the increasing length of the grape shoots and the budding out of later varieties of grapes.

On March 30, fifty sportsmen were invited to assist in the drive. A number of pigeons were killed and although the rest were kept stirred up, they were not discouraged but kept alighting in the vineyard. As a result of publicity some 300 sportsmen assembled on March 31 and April 1; yet the birds continued to come in by the thousands. On April 2, about 500 men appeared at the vineyard with about 200 rounds of ammunition each, and it was said that "a bombardment such as has not been heard since the First World War took place from daylight to about noon." Not a pigeon was given a chance to alight.

On April 3, hundreds of hunters appeared but no pigeons came. A survey of the vineyard by officials revealed fewer than a dozen birds during the entire forenoon, and inspection of the roost indicated that they had deserted the area. It was estimated that between 5,000 and 7,000 pigeons were killed.

These reports indicate the problems that develop in herding off pigeons by gunfire when they range in numbers from a few birds to almost a quarter million. As intimated by Tonkin and Britton, and fully substantiated by the experience of countless farmers and game officials, timing the protective effort is most important. Control work should be started at the first evidence of crop loss, not after the pigeons have fed long enough to become accustomed to the area. It is far easier to discourage the birds at the beginning of an attack than after the flight has developed to large proportions.

Herding off pigeons with gunfire remains the standby, with advantages and disadvantages as herein pointed out. It is costly; it requires a large quantity of black-powder ammunition and constant patrol by gunners whose numbers depend on the size of the area to be patrolled. Rifle fire, although effective, is too dangerous in most localities.

As already reported, scarecrows appear to have no effect on the pigeons. Airplane herding was of no avail. Feeding the pigeons in their mountain haunts proved possible, but was so costly that it was impracticable.

John C. Knox, United States Game Management Agent, in June and July of 1940 and 1941, made extensive and fairly successful tests of frightening devices in the cherry orchards of Mountain Park, N. Mex. He described the results obtained with the use of 
the automatic acetylene flash gun² known to be of value in preventing depredations by various species of birds.

One of these "guns" was operated near High Rolls in an orchard of 30 cherry trees. Before its installation 40 pigeons had fed in these trees morning and evening for more than 10 days. When the exploder was timed so that explosions occurred at 10 minute intervals, the pigeons were kept away from the trees, and when it was regulated so that explosions occurred every 3 minutes the jays, robins, orioles, and grosbeaks were controlled to an estimated 80 percent. At the end of the 1941 test, Knox concluded that the use of 10 or 12 acetylene flash guns together with a limited amount of concurrent shotgun shooting would effectively solve the problem in that area.

An adaptation of the "flagging" system commonly used against horned larks in truck crops in California ${ }^{3}$ was tested. In 1940, in an orchard of 150 trees a cord was stretched over the tops of the trees in each row. Between and near each tree streamers made of white wrapping paper were tied to the cord so that they waved in the rather constant breeze and made considerable noise. For 7 days after the installation of this device, no pigeons fed in the orchard. Then a severe rain and wind storm destroyed the papers. In 1941 streamers made from a durable kraft crepe paper with an asphalt inner binding were tested. This paper proved very successful during dry weather in frightening the pigeons. It withstood rain and wind, but when wet it made no noise. Apparently it was the crackling and popping of the streamers rather than their motion that frightened the pigeons, for when the crepe paper streamers ceased to make noise, they lost their effectiveness and the pigeons returned.

A spotlight beacon useful in frightening away night-feeding ducks ${ }^{4}$ was tested against the day-feeding pigeons, but proved ineffective, as did also strips of paper, cloth, and bright tin hanging in the trees.

Knox demonstrated that tree covers made of tobacco cloth were both effective and economical. Cover for trees of various sizes were made at costs ranging from 50 cents to $\$ 3$ each. Because pigeons prefer the higher branches, the covers were so constructed as to cover only the upper parts of the tree, but where other birds are plentiful extension of the covers to protect the entire tree might

\footnotetext{
2 The acetylene flash gun is a commercially manufactured device consisting of a carbide, water, combustion, and flash chambers. A controlled flow of water entering the carbide chamber forms acetylene gas. When pressure forces release of the gas. it is ignited by a pllot light and explodes with a report similar to that of a shotgun, and with a blinding flash of light. By means of the valve controlling the water flow, the apparatus can be get to explode at almost any ciesired frequency. Information on where this and other birdfrichtening devices can be obtained can be furnished by the Fish and Wildlife Service. Department of the Interior, Chicago 54 , Ill.
}

Protecting crops from damage by horned larks in California. By Johnson A. Neff, Biologtst. U. S. Dept. Agr., Bureau of Biological Survey Wildlife Research and Management Leaflet BS-64, 10 pp., illus., September 1036. [Processed.]

4Protecting field crops trom waterfowl damage by means of reflectors and revolving beacons. By F. M. Uhler. Biologist, and Stephen Creech, Game Management Agent. U. S. Dept. Int., Bureau of Biological Survey Wildife Leaflet BS-149, 6 pp., illus. November 1930. [Processed.] 
be well worth while. As the covers would be in use only about 30 days of each year, if carefully handled they should last for several seasons. The writer on many occasions has observed similar covers used to protect vines and fruit trees, the most elaborate being a gas-pipe-chicken-wire structure covering large sweet cherry trees.

Near Hermosa, Colo., in 1942, Game Management Agent Poley found the acetylene flash gun very ineffective unless it was moved about the orchard several times daily and was accompanied by liberal gunfire. Pigeons were seen feeding in the tree adjoining the flash gun after it had been operating for almost an hour. In the same area, in 1943, white Very signal flares were tested and proved most effective in frightening pigeons from the orchard. Their use was restricted by the great fire hazard in all places where the ground cover was inflammable. Pyrotechnic 3-inch flash bombs such as are widely used for frightening ducks were also tested in cherry orchards and proved to be very satisfactory, having greater value than gunfire.

Studying the depredations on cherries at Cloudcroft, N. Mex., Frank C. Knox, Game Agent, found that a small number of wild mulberry trees grew in the mountain canyons near the cherry orchards. The fruit on these trees normally ripened about 2 weeks after the earliest cherries were ripe, but before the late cherries ripened. He first noticed that the pigeons were more easily driven from the cherry orchards after the mulberries began to ripen. Then, in 1943, weather conditions caused the early cherries and the mulberries to ripen at the same time; a large part of the pigeons remained in the canyons feeding on mulberries and did not come to the cherry orchards until the mulberry crop was exhausted, at a time when most of the cherry crop had been harvested. Similar conditions existed near Paonia, Colo., in 1945.

Knox's observations led him to believe that the planting of early ripening mulberries in the canyons of the Cloudcroft area would go far toward reducing the cherry damage there. Such a method of prevention might well be practicable in districts in which the pigeon population is moderate to small, but it is the writer's opinion that it would not prove effective in areas in which the pigeon population is very large, for severe crop depredations have been noted in many instances in areas where pigeons were abundant and where the native wild food supply was far greater than was necessary for the birds. The effectiveness of the method probably depends largely on local conditions.

Studies of methods of crop protection by means of deterrent and frightening devices have not kept pace with field needs, and further extensive experimentation is desirable. Man's ingenuity in devising noise-makers and frightening devices has scarcely been tapped, and much can doubtless be accomplished along this line.

Each complaint of pigeon depredations should be carefully investigated by either State or Federal officials, and when damage is found to have occurred, the victims should be given every practicable assistance.

Because of the fondness of band-tailed pigeons for agricultural crops, good management decrees that the pigeon population should 
not be permitted to increase unreasonably; therefore carefully planned open seasons should be continued so that shooting will act as a population control, particularly in areas in which pigeons are abundant and depredations severe. Open shooting seasons, however, are not the remedy for specific instances of depredation for because of the habits of these birds control of depredations by hunting could be realized only through general and widespread population reduction, which is undesirable.

The issuance of permits to kill pigeons that are damaging crops has never been completely successful. Earlier authorizations allowed the owner or lessee to use the birds so killed for food, and as a result a great demand for permits developed, the desire to hunt being the primary motive. Hence permits no longer include the privilege of utilizing the birds killed as food, and significantly there has been a great decrease in the number of complaints. During recent seasons it has been possible in some areas through agreement between Federal and State officials to require the permittee to preserve the pigeons killed for delivery to charitable institutions or hospitals. This has effected further decrease in the number of requests for permits.

Another defect of the permit system is that shooting usually is allowed only on the area on which damage is occurring; but, as has been pointed out by Britton in New Mexico, shooting the pigeons at their roosting and perching sites may aid greatly in reducing the damage. These roosts and daytime perching trees may be near the crop attacked or may be miles distant.

Where important crop losses occur, it would often facilitate protection if the owner were permitted to shoot the birds on his property while at the same time game wardens or men under their immediate and close supervision traced the flight of the pigeons and continued the frightening process at perching and roosting places until a change in flight lines or the habits of the birds brought relief. This procedure, however, would require a large personnel and a great expenditure of funds.

There can be no question that serious agricultural losses sustained by persons on account of depredations by band-tailed pigeons must be controlled. On the other hand, conservation sentiment demands that there be no excessive or unwarranted destruction of the birds. Pigeon depredations affect a large number of persons, especially in mountain, valley, or wilderness areas close to abundant bandtail populations. In many cases there is a distinct loss, but in many others the damage is magnified. Regardless of the degree of damage incurred or of the justification for control of the birds on the individual farm, studies of methods of prevention of damage have lagged, and there are few economical, practicable, and highly successful methods that can be recommended. Where the farmer will get out with his gun at daylight and keep the pigeons from feeding in his field until dark usually only one to three days are required to break up even the worst of the normal pigeon attacks. 


\section{FOOD HABITS}

\section{GENERAL}

The literature on the band-tailed pigeons contains many references to their feeding habits, mostly based on field observations. Huey (1913) describes their feeding on manzanita berries in California, Willard (1916) on acorns of Quercus emoryi in Arizona, Gilman (1903) in grain stubble in California, and Taverner (1934) on peas and grain in British Columbia. Bendire (1892) quotes Carpenter relative to the feeding of the pigeons on the salmonberry (Rubus nutkanus) along the Columbia River, and Kobbe (1900) confirms the report. Belding comments on their feeding on acorns and oak buds in California, Ankeny on their eating acorns in the Rogue River Valley of Oregon, and Lloyd on their consumption of wild grapes in western Texas and of acorns there and in Mexico. From Arizona Benson reported to Bendire that acorns were taken after July 15 , and Poling mentioned mulberries, although not definitely stating that the fruits were eaten.

Dawson (1923) said the bandtails fed on elderberries (Sambu. cus), cascara (Rhamnus purshiana), coffeeberries (Rhamnus californicus), huckleberries (Vaccinium), salal (Gaultheria), salmonberries (Rubus), madrona berries (Arbutus), and Christmasberries (Photinia), but that acorns were their favorite food.

Gabrielson and Jewett (1940) summarize the food of the birds in Oregon as consisting of acorns, mountain ash berries, berries of various species of Rubus, elderberries, and currants ; kinnikinnick, dogwood, and other fruits; grains; and peas and other legumes. They mention that after nesting time, when the birds flock together, they feed on the fruits of salal, salmonberry, blackberry, and other wild fruits; Jewett has stated that they are particularly fond of the cascara berry (Rhamnus purshiana) ; and Gabrielson frequently observed them apparently feeding on the seeds of $\mathrm{Lu}$ pinus lyalli.

Mrs. Bailey (1928) summarizes the food of the species as follows: "Mainly nuts, especially acorns, and berries, including wild currant, chokecherry, wild cherry, juniper, madrone, manzanita, raspberry, blackberry, elderberry, huckleberry, salmonberry, coffeeberry (Rhamnus californica), Christmasberry, and black gooseberry; wild grapes, flowers and leaf buds, sycamore balls, pine buds, seeds, and needles, and grain (mostly waste) ; together with grasshoppers and other insects."

Grinnell, Bryant, and Storer (1918), in Game Birds of California, say that "the amount of food available to the pigeon appears to be the main controlling factor in its distribution. This is more particularly true in winter, though probably to some extent in summer also." They pointed out that the food consisted mainly of nuts and berries, and that the plants that bear these are frequently alternate-year, or intermittent, crop-bearers.

of 22 food records summarized by these authors, 10 give acorns as the chief item. Specifically, these included the acorns of Quercus agrifolia, Q. wislizenii, Q. kelloggii, and Q. chrysolepis. Berries of the madrona (Arbutus menziesii) were said to be an at- 
tractive autumn food. Fruits of certain species of manzanita (Arctostaphylos) were reported as taken from the time they were first formed until very late in the season when fully ripe. During the autumn, fruits of the coffeeberry, elderberry (Sambucus glauca), and chokecherry (Prunus demissa) were mentioned as favored foods, and in the winter, berries of the toyon (Photinia arbutifolia) were taken.

Buds and blossoms also were taken. Dean (1904) reported the bandtails feeding on manzanita buds, and there are many records of their eating oak buds and flowers. Evermann (1886) found 35 of the ball-like flowers of the sycamore in the crop of a single pigeon. Pine seeds were recorded as bandtail food by Belding (1890) and Grinnell (1905). Cultivated grains, including wheat, barley, oats, milo maize, and field corn, have been listed in numerous instances. Many miscellaneous items are recorded, including wild peas, dogwood berries, hazeinuts, alder seeds, and juniper berries. In New Mexico, H. W. Henshaw (1886) observed the pigeons feeding on fruits of the elder (Sambucus racemosa) and acorns of the scrub oak (Quercus undulata).

J. A. Munro, Chief Federal Migratory Bird Officer, of British Columbia, reported in 1941 on the examination of the food of 13 bandtails collected in British Columbia between 1923 and 1933. The crop of a bird collected in June contained approximately 346 kernels of wheat. Of 12 birds collected in September, the crops of 6 contained field peas, and those of the others such items as acorns of Quercus garryana, seeds of Cormus nuttalli, Sambucus glauca, Gaultheria shallon, and oats.

Several writers have commented on the great volume of food that can be taken by a single pigeon. Grinnell, Bryant, and Storer mention an acorn dropped by a flying pigeon that measured nearly 1 by $11 / 2$ inches, and also record a pigeon killed in Del Norte County, Calif., whose crop contained 534 kernels of barley, oats, and corn.

Van Rossem (1914) reported finding pigeons in a dying condition, their crops pierced by acorns that they had swallowed. John G. Traub, of the Fish and Wildlife Service, who ranched for a time in San Luis Obispo County, Calif., told the writer of killing apparently healthy pigeons that upon examination were found to have points of acorns protruding through the crop wall; the feathers were matted with crop juices, an indication that this condition had existed for several days, yet the pigeons had apparently continued to feed and fly vigorously and normally.

E. H. Glidden, State Game Warden, of San Diego, Calif., wrote on December 10, 1937, "You will find the chief diet of wild pigeons at this time of the year in this district to be acorns; however, one may at times find the young shoots of pines in their crop, especially on Palomar and the Mesa Grande Mountain. During the spring they feed almost entirely on elderberries."

W. H. Ransom, United States Game Management Agent, said in 1937 that madrona and mountain ash berries were supposed to be choice winter foods for the small number of pigeons that wintered about Seattle, Wash., and that in June the bandtails fed on ripened 
wild strawberries in great numbers, especially on Sand Island near Willapa Harbor.

Lawrence W. Saylor wrote: "I once kept an injured bandtail for two weeks ... and it would eat as many as 30 madrona berries a day; it also accepted and ate huckleberries (Vaccinium ovatum), coffeeberries, cultivated currants, and strawberries, and on several occasions readily took grasshoppers when offered. . . . Apparently the tips of Douglas fir branches are eaten (by the wild birds), as I have stood under the trees and watched the birds pick at and swallow the tender tips of the twigs."

There is frequent mention of insects as food of these pigeons, but it would seem that most of these references trace to a field examination made by Vernon Bailey, on July 29, 1903, of a pigeon killed by him at Pecos Baldy, N. Mex., of which he said, "The gizzard was full of insects, mainly grasshoppers and the larvae of a wasplike insect." Despite this observation, and those of Saylor just mentioned, pigeons as a group eat little animal food.

Several writers have described feeding mannerisms of bandtails. Gilman (1903) says that "instead of spreading out they kept together alternately walking and flying. Those behind would fly a few feet ahead of the advance line, alight, and walk along picking up grain until other rear ones would fly ahead and it came their turn again."

Huey (1913) stated that a flock observed feeding on manzanita in San Diego County arrived a little after sunrise and left between eight and nine o'clock in the morning; in the afternoon the birds returned about four and left again at dusk. Willard (1916) described the bandtails feeding on acorns in Arizona: "They would walk out on the slender branches till they tipped down, then, hanging by their feet, would secure an acorn, and drop off to alight on a branch lower down."

In mid-June 1941, pigeons numbering possibly 12 to 20 came from the Pinaleno Mountains to a group of mulberry trees on a ranch 7 miles south of Pima, Ariz., to feed upon the ripening fruits. The distance from the mulberry trees to the oak-pine zone high up the side of Mount Graham must be at least 10 miles. Two specimens of bandtails were obtained here, giving the first representation of mulberries in stomachs in the entire study although this fruit was known to be well accepted.

In May 1932, the writer saw two migrating bands of pigeons flying across the broad Sacramento Valley of California stop to feed upon seed rice in two newly planted fields.

During the course of intermittent field work on band-tailed pigeons extending from 1936 through 1941, the writer has personally observed, or has received reports from cooperators who have observed, the birds feeding on most of the food already mentioned in the abstract of the literature on pigeon foods. In some instances no specimens of bandtails were obtained, hence the particular item does not appear in the tabulations of the result of stomach examination; in other cases the item may be represented in unnaturally small ratio owing to lack of adequate collecting in a habitat providing that particular food. 


\section{USE OF MINERAL SALTS}

In 1937, many Puget Sound observers noted that the pigeons frequently flew to mud flats at the margin of the Sound to drink salt water even though fresh-water streams were available. In this connection W. H. Ransom (in a letter of April 15, 1939) writes: "Near Cathlamet, Wash., along the Columbia River there is a cliff containing saline deposits of some sort, and the game protector stationed there a few years ago told me of seeing scores of pigeons gathered there in late summer, while groups of them fluttered in the air as close to the vertical cliff as they could get, all the while picking at the salt-bearing earth."

Frank B. Wire, of the Oregon Game Commission, told the writer that many years ago he had frequently hunted pigeons at a salt spring that attracted the birds in considerable numbers. Bendire (1892) quotes Anthony relative to a large salt spring south of Beaverton, Oreg., where pigeons were always to be found in large numbers. Kloppenburg (1922) writing of the bandtails in the Plumas National Forest in California says that "they can usually be found near mineral springs, especially soda and sulphur springs."

This habit may be analogous to that of the mourning doves that are attracted to salt in the Southeastern States to such extent that the use of salt is included as a prohibited method of baiting. In Arizona the writer has observed western white-winged doves picking at salt blocks in cattle feed lots. Salt was used as bait also in connection with the shooting of the now extinct passenger pigeon.

\section{RESULTS OF LABORATORY EXAMINATIONS}

The following report covers the laboratory examination of 691 band-tailed pigeon crops and/or stomachs. This material admittedly is inadequate, some States being represented by only a few specimens. In California, the pigeons occur at some time of year in most of the more than 50 counties, but only 18 of them are represented in this study, and 194 out of 267 stomachs were salvaged from the bags of hunters during the 15-day December open season; likewise, 113 of the Washington specimens were procured from hunters during the 15-day September open season, in 1937.

For the purpose of this report the crop and stomach, or the crop or stomach, of an individual bird is considered a unit specimen. Every effort was made to obtain both crop and stomach, but since many specimens were obtained from hunters, it was found diffcult to obtain both, and in many instances only the crop or the stomach was obtained. Regularly cooperating observers, however, sent in both crop and stomach.

The food percentages in this report have been computed by the standard volumetric method described by Cottam, 5 each item be-

Economic ornithology and the correlation of Jaboratory and field methods. By Clarence Cottam. Biologist. U. S. Dept. Agr.. Bureau of Biological Survey Wildlife Research and Management J.eaflet BS-80, 18 pp., illus. January 1086. [Processed.] 


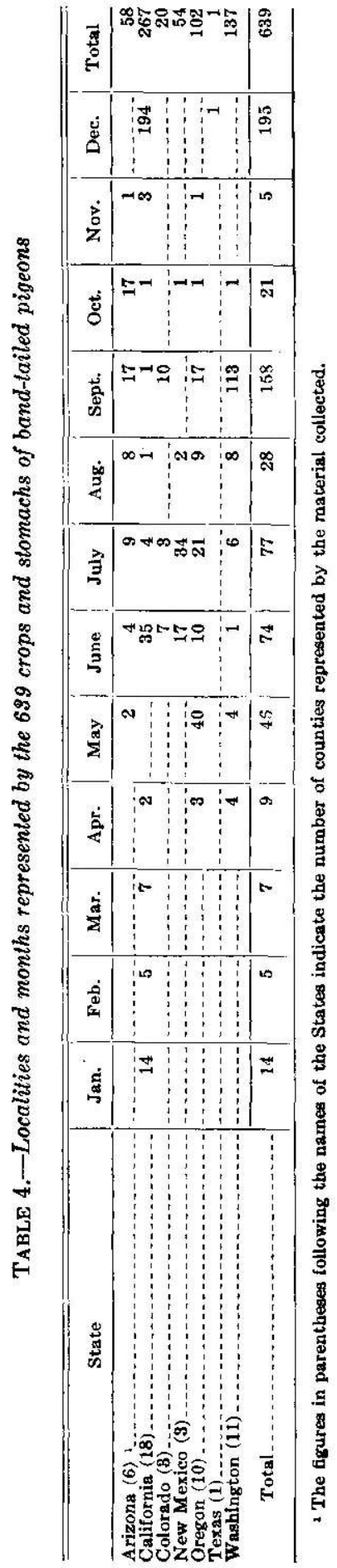




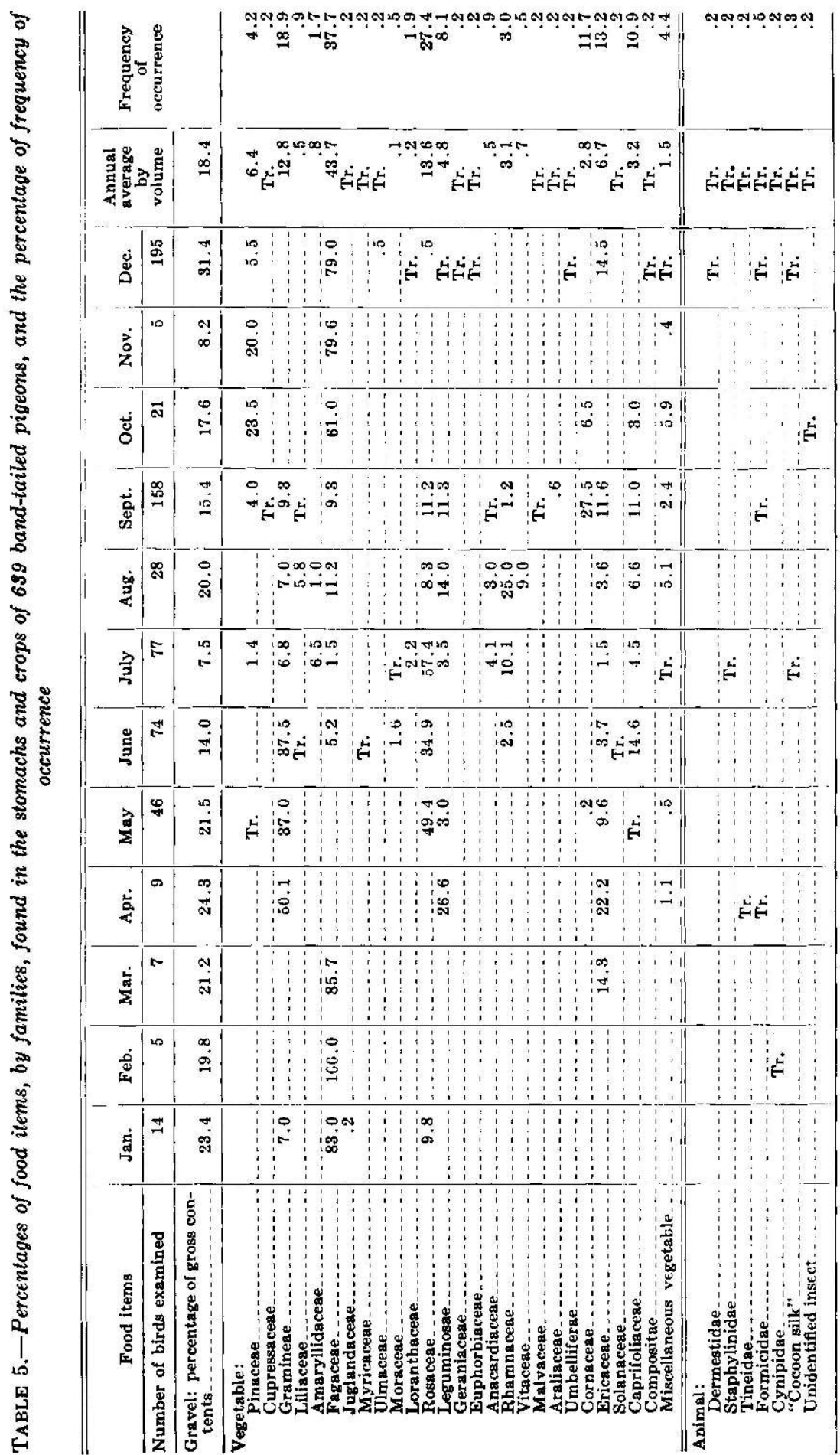


ing measured after drying. Although representation varies greatly, the month is used as the period for the computations. For plant names the most recent publication on taxonomic botany for each of the States has been used.

Of the specimens available, 25 had such incomplete data that they were useless, although information obtained from them may be mentioned; 27 others were so nearly empty that they were eliminated from the tabulations. Hence the percentages of food volume and frequency of occurrence are based on the remaining 639 specimens.

In the examination of these, 76 separate classes of plant food items were listed, including unidentified mosses, vegetable debris, unidentifiable vegetable fragments, and rodent scats composed entirely of vegetable debris. The identified plant-food items represent 26 plant families. In addition, 10 occurrences of insect fragments, comprising only a trace of the whole food, were recorded. Hence the species may be considered almost wholly vegetarian. Gravel in stomachs is figured in its ratio to the total content, while food item percentages are calculated after the grit has been removed.

In table 4 is summarized by States the material available for each month; the number in parentheses following the name of the State refers to the number of counties represented by the stomachs collected.

In table 5 are listed the general classes or families of food items represented, by months, with the composite percentage by volume of all species within the family, based on a total of 639 stomachs and crops. An added column gives the percentage of frequency of occurrence of the combined species of each family.

The percentages by volume and frequency of occurrence of the

TABLE 6.-Percentage by volume and frequency of occurrence of the food items that totaled one percent or more of the annual food of 639 bandtails, based on the examination of their stomachs and crops

\begin{tabular}{|c|c|c|}
\hline Food item & $\begin{array}{c}\text { Percentage by } \\
\text { volume }\end{array}$ & $\begin{array}{l}\text { Percentage by frequency } \\
\text { of occurrence }\end{array}$ \\
\hline 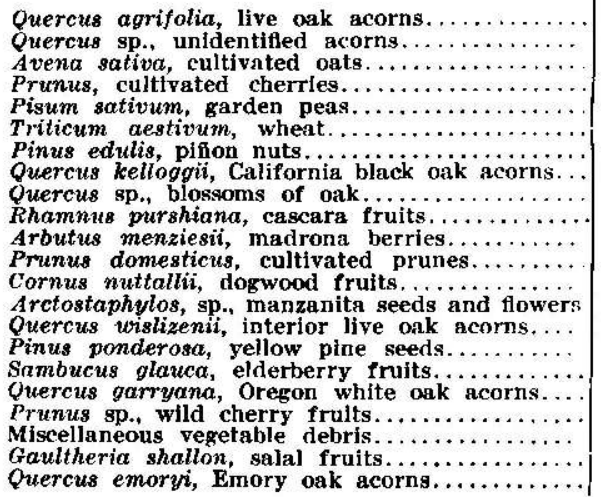 & \begin{tabular}{r|r}
17.5 \\
13.4 \\
7.4 \\
7.1 \\
4.8 \\
5.0 \\
4.0 \\
8.9 \\
8.5 \\
8.0 \\
3.0 \\
8.0 \\
2.8 \\
2.8 \\
2.2 \\
2.0 \\
1.8 \\
1.7 \\
1.5 \\
1.5 \\
1.0 \\
1.0
\end{tabular} & $\begin{array}{r}11.1 \\
18.2 \\
5.8 \\
12.4 \\
7.4 \\
10.3 \\
1.9 \\
1.6 \\
1.3 \\
2.8 \\
6.1 \\
3.0 \\
11.7 \\
3.1 \\
2.0 \\
.3 \\
6.4 \\
.8 \\
6.0 \\
4.4 \\
3.8 \\
1.7\end{array}$ \\
\hline
\end{tabular}


food items that totaled 1 percent or more of the annual food of the bandtails, as based on the examination of the 639 stomachs and crops, are shown in table 6.

Pinaceae ( 6.4 percent).--Buds of the Sitka spruce (Picea sitchensis) were found in a May-killed Oregon bird, and staminate aments of an unidentified conifer in another. Unidentified pine seeds were found in one California bird killed in December. Seeds of the yellow pine (Pinus ponderosa) were found in two California birds collected in June and December, respectively. One bird obtained in July in the Kaibab National Forest, Ariz., contained 625 seeds of this pine, measuring 47 cubic centimeters (4 cubic centimeters $=1$ teaspoonful).

Nuts of the piñon (Pinus edulis) were found in 12 Arizona birds collected in September, October, and November. These nuts were the only food in 11 of the birds and composed 94 percent of the food of the other. Nuts of the single-leaf piñon (Pinus monophylla) composed the entire food of 9 pigeons and 90 percent of the food of a tenth collected in California in December. One bird had taken 60 of the nuts which displaced 45 cubic centimeters.

Cupressaceae (trace).-One pigeon killed in Arizona in September contained 270 staminate buds of an unidentified juniper (Juniperus).

Gramineae (12.8 percent).-Cultivated grains make up a moderate portion of the food of the band-tailed pigeon in or near farming areas. Wheat occurred in 66 birds collected during 7 months of the year in 4 States and averaged 5.0 percent of the annual food. Oats were found in 37 birds collected in 3 States during 5 months and formed 7.4 percent of the annual food. Barley occurred in 12 birds collected in 2 States during 4 months and formed 0.4 percent of the annual food. Field corn was found in only 2 September birds from Colorado.

Unusual quantities of grain were found in a few crops; one contained 725 kernels of wheat, one 200 kernels of barley, and another 660 whole kernels of oats.

Seeds of Poa sp., wild oats (Avena fatua), darnell (Lolium temulentum), and needlegrass (Stipa sp.) were each found in single stomachs of birds taken in April, May, and June in Oregon and California. The family Gramineae contributed 12.8 percent of the annual food.

Liliaceae ( 0.5 of 1 percent). - Seeds of an unidentified yucca were found in one California bird collected in June, and seeds of sotol (Dasylirion wheeleri) (fig. 9) in three August and two September birds from southeastern Arizona. Combined they made up one-half of 1 percent of the annual food.

Amaryllidaceae ( 0.8 of 1 percent).-Ten birds collected in July and August in southern New Mexico contained the anthers of an agave (Agave parryi) (fig. 10), aggregating 0.8 of 1 percent of the annual food, and one Arizona bird killed in August contained 125 seeds of a Smilacina, probably stellaria.

Fagaceae (43.7 percent). - The acorns and flowers of oaks constitute the major food of the band-tailed pigeon. Staminate flowers of oak were found in four January and four March birds from 


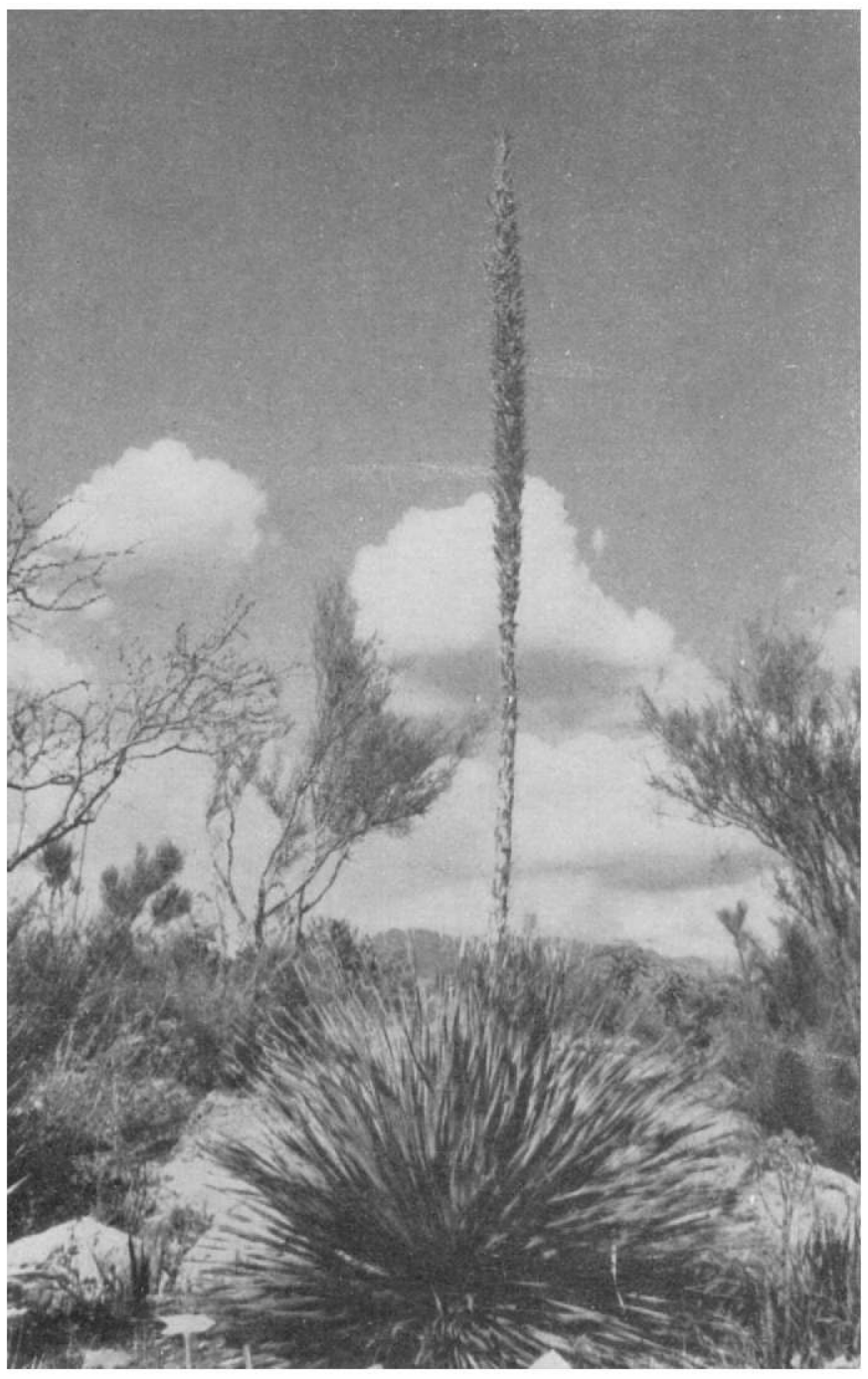

B871/M

Figune 9.-Pigeons from the oak canyons of the Southwest often feed on the seeds of the sotol (Dasylirion wheeleri), which grows in the adjacent high desert. Pinal County, Ariz. (Photographed by H. L. Crockett, July 1941.)

California. Acorns or fragments of acorns were found in 233 birds collected during 10 months and from every State represented except Texas. Oak products totaled 43.7 percent of the annual food.

Acorns of the California live oaks were most frequently taken; those of the coast live oak (Quercus agrifolia) occurred in 71 stomachs and averaged 17.5 percent of the year's food, and those of the interior live oak (Q. wislizenii) were found in 13 birds col- 


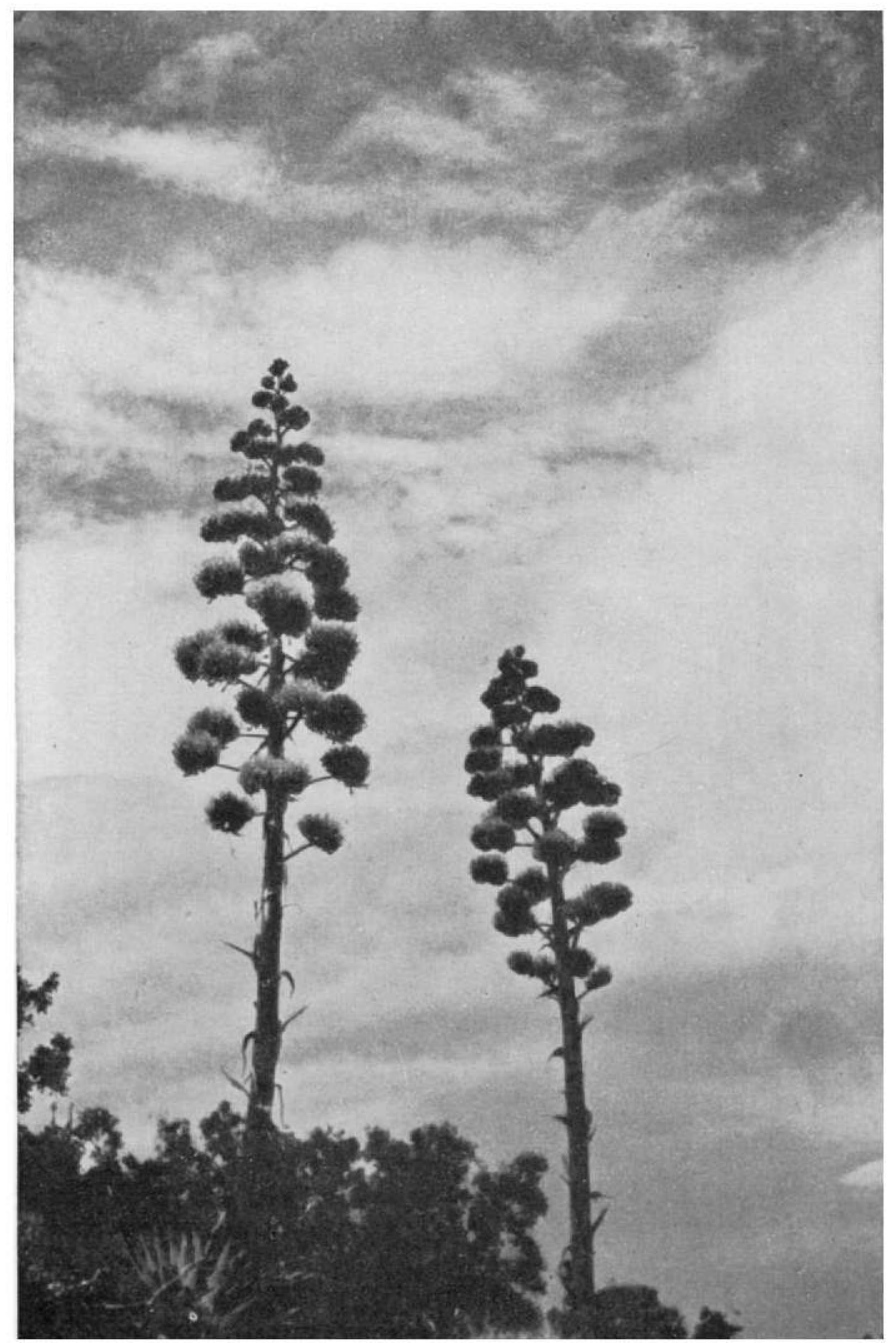

B8712M

Figur: 10.-The flowers of this tree-like agave (Agave parryi) furuish summer food for pigeons in the Southwest. The agaves grow in the higher desert mountains, sometimes very close to pigeon-nesting habitat. Head of Mills Canyon, Pinal Mountains, Ariz. (Photographed by H. L. and Ruth Crockett, July 26, 1936.)

lected during the period November to March. Other species represented were the California black oak $(Q$. kelloggii $)$, blue oak $(Q$. douglasii), Oregon white oak (Q. garryana), Emory oak (Q. emoryi), white-leaf oak (Q. hypoleuca), and the valley oak (Q. lobata). Fragments of acorns not further identified were found in 116 birds and averaged 13.4 percent of the annual food. The abil- 
ity of these birds to consume quantities of acorns has been described. The crop of one specimen examined contained 22 acorns of the coast live oak, displacing 38 cubic centimeters.

Juglandaceae (trace).-One California bird killed in January contained flowers of the walnut (Juglans).

Myricaceae (trace).-Parts of the seeds of the wax myrtle (Myrica californica) occurred in one California specimen.

Ulmaceae (trace).-Seeds of an unidentified hackberry ( $\mathrm{Cel}$ tis) were taken from the stomach of a bird collected at Uvalde, Texas, in December. Pigeons collected in the Capitan Mountains of New Mexico had eaten fruits of Celtis reticulata.

Loranthaceae ( 0.2 of 1 percent). - The pine mistletoe (Arceuthobium) was represented in nine December stomachs from California and three July stomachs from New Mexico by fragments of both fruiting and vegetative parts.

Moraceae ( 0.1 of 1 percent). - Fruits of the mulberry (Morus $a l b a$ ) occurred in two June birds from Arizona, and seeds of an unidentified mulberry in one July bird from New Mexico.

Rosaceae (13.6 percent).-This family, producing many familiar wild fruits and berries, is well represented in the bandtail's diet. Seeds of wild blackberries or raspberries were found in 14 birds; eight were unidentified; and salmonberry (Rubus spectabilis) occurred in four, and a wild blackberry (Rubus macropetalus) in two birds. Rose hips were found in one stomach.

Wild cherries, including Prunus emarginata and $P$. melanocar$p a$, were found in 44 specimens collected in Washington, Oregon, Colorado, and New Mexico. Fruits of Prunus emarginata occurred in 38 Washington specimens taken in July, August, and September, and averaged 1.5 percent of the annual food.

Seeds of the serviceberry (Amelanchier alnifolia) occurred in five September birds, and those of the hawthorn (Crataegus douglasii) in four July birds from Oregon. Seeds of the wild strawberry (Fragaria) were found in two May specimens, and fruits of the toyon (Photinia arbutifolia) in four December birds.

Cultivated prunes were found in 19 birds collected in May in the Willamette Valley of Oregon, and averaged 3 percent of the annual food. Cultivated cherries occurred in 79 birds collected from May to August in Washington, Oregon, California, New Mexico, and Colorado, and formed 7.1 percent of the total food. Both the sweet cherry (Prunus avium) and sour cherry (P.cerasus) were represented. The Pacific coast fruits were entirely sweet cherries, but in Colorado and New Mexico both varieties were included in the food of the pigeons. The combined products of the Rosaceae family averaged 13.6 percent of the annual food.

Leguminosae ( 4.8 percent). - Seeds of clover (Trifolium), lupine (Lupinus), and trefoil (Lotus), and leaves of Trifolium were all found in the crop of a single California bird.

Cultivated peas had been taken by 44 bandtails collected in Washington. Those found in seven April and May stomachs had been gleaned from freshly seeded fields and averaged slightly more than 2 percent of the annual food; the significance of such feeding has already been discussed (p. 44). During July, August, and 
September peas are taken mostly from the stubble of harvested fields. Occasionally the birds may attack a field that is to be harvested for seed, causing severe losses. For the entire year, cultivated peas, waste or valuable, averaged 4.8 percent of the food.

Geraniaceae (trace).-A few tiny leaves of the alfilaria (Erodi$u m$ ) had been eaten by one California bird.

Euphorbiaceae (trace).--Seeds of the turkey mullein (Eremocarpus setigerus) were found in one specimen.

Anacardiaceae $(0.5$ of 1 percent $)$. - Seeds of two species of sumac were found. Those of Rhus emoryii occurred in the stomachs of five specimens from New Mexico, and those of $R$. trilobata in one bird from Arizona, making up 0.5 of one percent of the annual food.

Rhamnaceae ( 3.1 percent). -The berries of the cascara ( $R$ hamnus purshiana) are a favorite food in Oregon; these fruits were taken from 18 Oregon specimens collected from June to September and averaged 3 percent of the annual food. Seeds of the coffeeberry ( $R$. californica) occurred in one California stomach. Fruits and seeds of the lote bush (Condalia lycioides) were identified from a single Arizona specimen. Products of this family averaged 3.1 percent of the annual food.

Vitaceae $(0.7$ of 1 percent).-Fruits and seeds of the wild grape ( $V$ itis arizonica) composed the major food of three August specimens collected in the Huachuca Mountains of Arizona, and formed 0.7 of one percent of the annual food.

Malvaceae (trace).-A single seed, determined as Sidalacea sp., was found in one Oregon specimen.

Araliaceae (trace).-A number of green berries of Aralia humilis were identified from the stomach of a single Arizona bird.

Umbelliferae (trace).- Seeds of the gambleweed (Sanicula menziesii) occurred in one California specimen taken in December:

Comaceae (2.8 percent). - The fruits of the dogwood are a highly favored food, being found in 75 stomachs from Washington and Oregon, and averaged 2.8 percent of the annual food. Those of the mountain dogwood (Cornus nuttallii) are the most commonly taken.

Ericaceue ( 6.7 percent).-The heath family includes four groups, the fruits of which are relished by band-tailed pigeons and averaged 6.7 percent of the annual food.

In the Pacific Northwest the fruits of the salal (Gaultheria shallon) were taken by 24 birds from Washington and Oregon and averaged just 1 percent of the annual food. Fruits of the madrona (Arbutus menziesii) were eaten by 39 California birds and composed 3 percent of the annual food.

Flowers and fruits of the manzanita (Arctostaphylos) occurred in 20 specimens taken during every month from March to August in Oregon, California, and Arizona, and furnished 2.6 percent of the annual food. Fruits of two species of huckleberry (Vaccinium ovatum and $V$. delicosum) were identified, the first from a single Oregon bird, the second from two Washington birds.

Solanaceae (trace).-Seeds of Solanum sp., were found in one 
Colorado specimen.

Caprifoliaceae (3.2 percent).-Fruits and flowers of the elderberry (Sambucus) were found in 70 stomachs and averaged 3.2 percent of the annual food. Of these, the fruits in 41 specimens were identified as those of the blue elderberry (Sambucus glauca) and averaged 1.8 percent of the food; fruits in seven other specimens were identified as red elderberries (Sambucus callicarpa).

Compositae (trace).--One pigeon collected in California in December contained seeds of the tarweed (Madia).

Miscellaneous (1.5 percent).-Bits of moss were taken from one specimen. Fragments of oak galls were often found in pigeons that had been feeding on acorns. Unidentifiable vegetable fragments and debris were recorded from 17 specimens and averaged 1.3 percent of the annual food. One Oregon bird contained 12 whole rodent scats; the scats were entirely vegetable in composition and were tentatively identified as those of the wood rat (Neotoma).

Animal Foods.-All the insect material in the stomachs appeared to have been accidentally or incidentally taken; it was present in only 10 stomachs or crops.

One oak twig gall very similar to an acorn in size and appearance was found to contain larvae of gall flies (Cynipidae). A staphylinid larva (rove-beetle) and an adult Anthrenus (skin beetle), each in single stomachs, might have been taken incidentally in feeding on other items.

One stomach contained 7 honey ants (Prenolepis imparis) and a quantity of tiny leaflets of clover, and it is reasonable to assume that the ants were upon the leaflets when they were taken. One fire ant (Solenopsis) occurred in a crop otherwise filled with wild berries, and one acrobat ant (Cremastogaster) was also identified; both are frequently found about ripe fruits.

The larvae of a Tineid moth were found in one crop, traces of cocoon silk in two, and fragments of the elytra of a beetle in one. With all confidence the conclusion may be drawn that the bandtailed pigeon feeds only rarely upon insects.

\section{SEASONAL FOOD PREFERENCES}

In order to set forth more clearly the relation of foods to bandtailed pigeon migration and distribution, food items identified in the present study have been segregated and tabulated in four seasonal classifications: winter, spring, summer, and autumn. The seasons, arbitrarily designated, are most nearly accurate for the California district.

\section{WINTER}

The period designated as winter includes the months of November, December, and January. Normally, by November most of the pigeons of the Pacific coast have reached California and are settled in their winter habitat, except for descent from higher to lower elevations caused by snowfall. Soon after the end of January a movement northward includes part of the wintering popu- 
lation.

The stomachs and crops of 214 birds collected in four States during this period were available for examination. Acorns were taken by 172 of the 214 birds and averaged 77.2 percent of the winter food, with oak blossoms adding another 2.2 percent. Pine nuts also played an important part, contributing 8.5 percent to the winter food. Fruits of the madrona (Arbutus menziesii) were found in 37 of the birds and formed 4.8 percent of the season's food. Christmasberries, or toyon berries (Photinia arbutifolia), made up 3.4 percent, and wheat from stubblefields 2.3 percent, of the winter food. These were the only foods that averaged more than 1 percent.

Consideration of all data, both field and laboratory, leads to the conclusion that mast, acorns, and pine nuts are the basic foods necessary to maintain a population of band-tailed pigeons through the winter, and that these birds will not remain in numbers in areas that do not provide these foods.

\section{SPRING}

The period designated as the spring season covers February, March, and April. Beginning usually during February, the concentrations of bandtails that winter in central or southern California start to move slowly northward, and by the end of the period the majority of the pigeons of the west have reached their breeding range or are close to it.

Only 21 specimens were available for this period, collected in three States. Oak products, chiefly acorns, led in the spring foods; they were found in 13 specimens and averaged 62.2 percent of the season's food. Cultivated grain, including wheat, oats, and barley, and cultivated peas made up 25.4 percent of the food. This season covers at least part of the seeding period for certain of these crops, and in other areas winter wheat and barley is ripening by the end of the spring.

Other foods that averaged more than 1 percent during this period included fruits of the manzanita (Arctostaphylos), 4.8 percent, and of the madrona (Arbutus menziesii), 7.4 percent, the latter being found in only two stomachs.

\section{SUMMER}

During the summer period (May, June, and July) the majority of the pigeons are nesting, though some may not begin to nest until June, and may continue brooding until well after the end of July. Others may begin nesting before May and may be away from the nest and moving about before the end of July.

Examination of 197 specimens collected in six States furnished the data for the calculations for the summer period. Cultivated grains-wheat, oats, and barley--ranked high, averaging 25.7 percent, and were found in 80 specimens. It is certain that much of the grain was gleaned from stubblefields after harvest, and was therefore of little economic value. Cultivated cherries and prunes averaging 40.2 percent, led the summer food items, and occurred 
in 95 specimens; domestic prunes were taken during May while still very small; the cultivated cherries included both sweet and sour varieties and were taken at ripening season. Complaints against pigeons arise most frequently from their pilfering in cherry and prune trees.

Wild fruits of many kinds ripen during this period, and they are taken in wide variety. These include blackberries, raspberries, wild cherries, strawberries, elderberries, and fruits of the dogwood, hawthorn, lote-bush (Condalia), and others. Individually they composed from 1 to as high as 3 percent, and collectively 16.9 percent, of the summer food. The blossoms and berries of the manzanita and the berries of the sumac form an additional 5.8 percent.

Acorns comprise 5.6 percent of the summer food; some of these are gleaned from the ground under the oaks, but in the southern part of the range the acorns of the Emory oak and other species are reaching maturity and are taken from the trees. Pine nuts also enter the diet again as the new crop becomes available.

\section{AUTUMN}

During August, September, and October, the arbitrarily designated autumn period, migration on the Pacific coast is under way and in many cases is completed ; to considerable extent the same is true in the Rocky Mountain States and the Southwest. The crops and stomachs of 207 specimens collected in six States were available for this period.

With the ripening of the new acorn crop, these nuts rose in importance once more to 26.5 percent of the food and were found in 35 birds. Pine nuts made a further advance in the diet, averaging 9.2 percent and being found in 11 birds. Cultivated grains (wheat, oats, and barley) and cultivated peas were found in 71 specimens and averaged 13.7 percent of the food; most of this grain is taken from stubblefields. Wild fruits of many varieties continued to play an important part in the pigeon's diet. Fruits of the dogwood (Cornus) rose to 11.3 percent, elderberries to 7 percent, cascara (Rhamnus) to 8.2 percent, salal (Gaultheria) to 3.3 percent, wild grape (Vitis) to 2.8 percent, wild cherries to 6.0 percent, and a number of others ranked above 1 percent.

\section{DISCUSSION}

The seasonal food preferences of band-tailed pigeons as determined by the examination of 639 stomachs and crops are shown in table 7. The table lists the items that totaled 1 percent or more of the food for each of the four seasons and gives the percentage of their frequency of occurrence. The number in parentheses after the designation of the season refers to the number of specimens examined.

It will be noted that during three of the four seasons, oak products, largely acorns, and pine nuts, combined, led all other food items by a considerable margin. The availability of these nuts to a very large degree determines the distribution of the bandtailed pigeon; a number of the oaks bear acorns only at two-year in- 
(5)

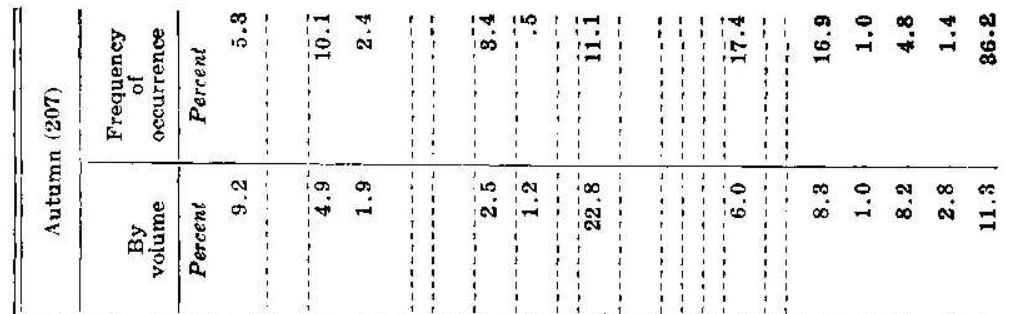

胥

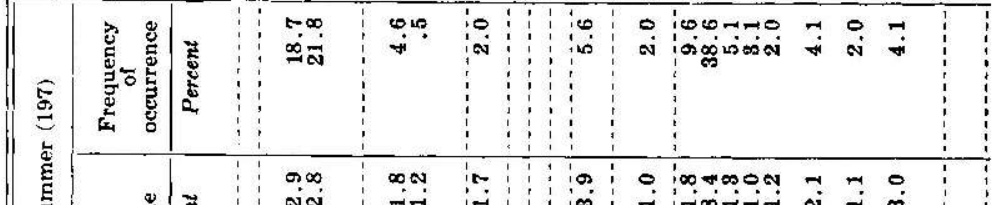

:

胥

है

(2)

8

है

莡

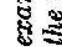

")

है

ช

岁

\&

है

हैं

号

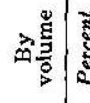

Nㅓ -

कe

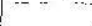

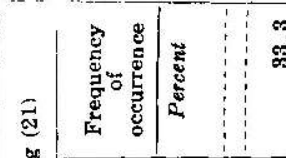

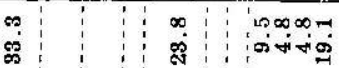

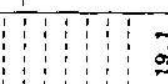

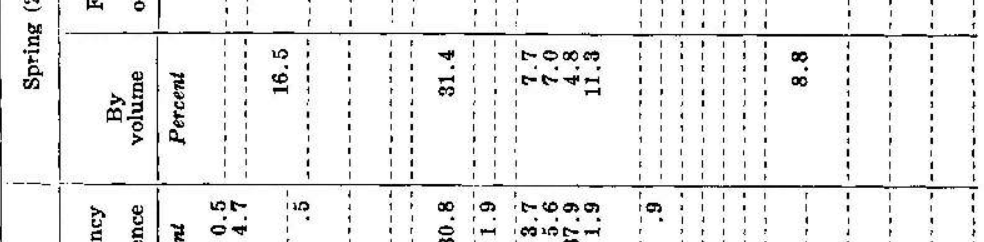

प्ष

है

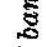

$\circ$

芯

8

急|

हैं लिक्ष

(

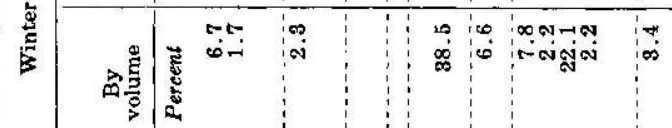




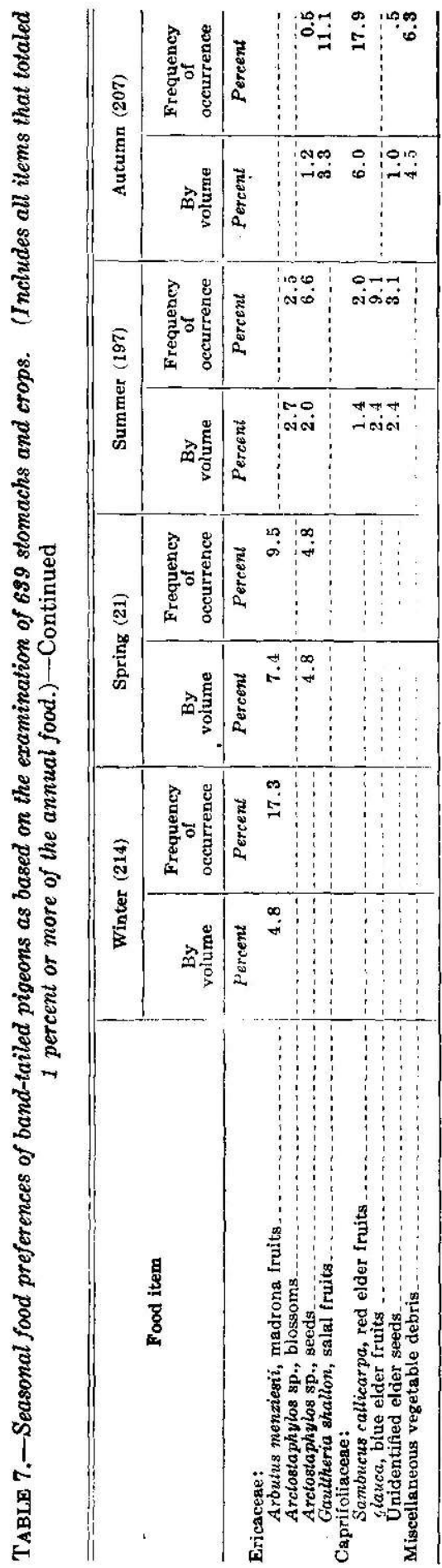


tervals, and both the acorn and the pine nut crops are frequently affected by adverse weather conditions. The winter range of the pigeon and its migration routes both northward and southward are directly influenced by the presence or absence of these nuts.

Band-tailed pigeons have developed a liking for cultivated grains and peas, as well as for cultivated prunes and cherries, and are sufficiently adaptable to have learned to congregate in areas where these crops are grown; yet study of the data available does not indicate that these crops are at all necessary for the maintenance of the present population. Wild fruits during the summer season and a plentiful supply of mast suffice to maintain them.

\section{USE OF GRAVEL}

As mentioned earlier, the grit or gravel found in the stomachs examined was measured according to its ratio to the total stomach content. Reference to table 5 shows that the volume of grit ranged from 7.5 percent in July to 31.4 percent in December. In examining stomachs of band-tailed pigeons, it becomes evident that the birds do not use gravel in the digestion of foods that have a hard pit, as wild and tame cherries and seeds of dogwood; only rarely do stomachs containing these pits also contain gravel. Apparently the pits are softened by the digestive juices and broken by muscular action, the fragments then serving as grinding material.

\section{INFLUENCE OF AGE OR SEX}

No nestlings were included in the present food study. A small number of flying juveniles were examined, but a survey of the tabulations showed no difference in their feeding habits from those of adult birds, nor did the feeding habits of the adult male differ from those of the adult female.

\section{FEEDING MANNERISMS}

During this study the writer observed feeding mannerisms that have been described by others. The alternate walking and flying manner of feeding in grain stubble as described by Gilman (1903) was noted in several localities, and the birds hanging by their feet to reach food at the tips of branches, as recorded by Willard ( $p$. 53) was observed in connection with their feeding on acorns and elderberries.

With respect to feeding hours, in some instances at least, Huey's statement (p. 53) was found to be correct. At other seasons feeding appeared to be intermittent all day long, periods of feeding to satiation alternating with hours of perching quietly in some tall dead tree.

\section{QUANTITY OF FOOD TAKEN}

The quantity of food that can be taken at one feeding is almost beyond belief, and after heavy feeding a digestive period of 2 or 3 hours is needed before the bird is able to fly about in normal fash- 
ion. Owing to the usually contracted state of the stomach, it is difficult to estimate the normal capacity of the organ; however, it appears that few band-tailed pigeon stomachs contain more than 10 cubic centimeters of food and gravel, and that about 15 cubic centimeters is the maximum ( $4 \mathrm{cc} .=1$ teaspoonful).

The following itemizations are of actual crop contents measured by displacements when fully dried, and indicate the volume of food that a pigeon crop can hold : 227 whole garden peas, 67.6 cc.; 622 seeds of Pinus ponderosa, 47 cc.; 60 seeds of Pinus monophylla, 45 cc.; 86 seeds of Pinus edulis, 34 cc.; 22 whole California live oak acorns, $38 \mathrm{cc}$; and 56 whole Emory oak acorns, $40 \mathrm{cc}$. Unmeasured, but in every instance forming the entire content of a single crop were the following items, each the largest of its group: 725 whole kernels of wheat, 660 whole kernels of unhulled oats, 104 whole berries of toyon, or Christmasberry, 270 whole berries plus 550 seeds of elderberry, 56 whole fruits of madrona, 26 whole cultivated cherries, 69 whole wild cherries, 104 fruits of cascara sagrada, and 80 whole fruits of dogwood.

\section{SUMMARY}

This report on the band-tailed pigeon (Columba fasciata fasci$a t a)$, largest member of the pigeon family now found in the United States, is based on field studies in Arizona, California, Colorado, New Mexico, Oregon, and Washington, and on reports from observers in Nevada, Texas, and Utah. Observations from British Columbia and Mexico are also included.

Personal observations and reports received indicate that in Oregon, Washington, and California the bandtail either has shown a definite decrease or its numbers are static. In California the summer population seems to be increasing, but the winter population is no more than holding its own. In Arizona, Utah, and New Mexico the species appears to be slightly on the increase. In Colorado it seems that the population may be dropping back slightly from a moderate high reached two or three seasons back. In Texas the evidence indicates that the birds have not increased in the past 25 years and are barely holding their own.

On California largely depends the future of the band-tailed pigeon, as the bulk of the population spends the winter in that State. Owing to the response of the birds to an abundance of food, conditions may arise permitting excessive slaughter. Recognition should be made of this fact in designating bag limits, seasons, and shooting areas.

Adult bandtails weighed during this study ranged from 10.3 to 15.5 ounces. In length, the bird averages about 15 inches.

Within the United States the nesting season varies with the climate of the district inhabited, and in the 8 States where nesting is now known to occur specific records cover every month from March through October. There was no authentic nesting record for Colorado until 1945, when two nests were discovered. Nesting locations vary almost as widely as does the forest cover within the range. The nest is typical of the frail nests of all members of the 
dove and pigeon group.

Normally only one egg is laid. Incubation is said to be 14 to 18 days. For 20 days after hatching, the adults carefully brooded the squabs under observation in Colorado in 1945. The male came to the nest about $9 \mathrm{a} . \mathrm{m}$. and cared for the squab until between 4 and $5 \mathrm{p} . \mathrm{m}$., when the female returned and cared for the youngster until the next morning. When the squab was 20 days old both parents ceased brooding, and thenceforth each came to the nest only once daily to feed the young bird.

At 17 days of age the nestling weighed 4.9 ounces, and its middle tail feathers measured only $28 \mathrm{~mm}$.; at 26 days of age it weighed 8.5 ounces and the tail measured $75 \mathrm{~mm}$. as compared with the average $140 \mathrm{~mm}$. of the adult bird. The squab left the nest between its 28 th and 30 th days.

Discussion of food habits and economic status covers testimony obtained from numerous field observers as well as the results of the laboratory examination of 691 stomachs and/or crops. Of the stomachs and/or crops examined 639 contained sufficient food to serve in computations of the diet.

Mast (largely acorns and pine nuts) furnished the largest single element of the food of the bandtail; it was present in 268 of the specimens studied and averaged 50.1 percent of the total food. So important is mast to the welfare of the bandtail that it determines not only the bird's route of migration and wintering grounds, but indirectly the nature and extent of the damage these birds inflict on crops.

The birds' fondness for cultivated cherries and prunes was indicated by the presence of these fruits in 98 of the birds examined, comprising 11 percent of the diet. Other related fruits obtained from wild sources (blackberries, strawberries, serviceberries, and berries of toyon and hawthorn) increased the percentage of food referable to the family Rosaceae to 13.6.

Cultivated grains (wheat, oats, and barley) comprised 12.8 percent of the food, and their consumption reflects the bird's ability to adapt itself to the changing conditions of agriculture. A liking for cultivated peas, which composed nearly 5 percent of the food, is the basis for local concentration of the birds and at times the cause of damage.

Other items of vegetable origin acceptable to the bandtails are huckleberries, fruits of salal and other members of the heath family (Ericaceae), elderberries (Caprifoliaceae), and fruits of dogwood (Cornaceae) and cascara and other kinds of Rhamnaceae.

The animal food ingested by the adult bandtail appears to be taken accidentally; it comprises less than one-fourth of one percent of the total food. No nestlings were examined, but juveniles that had left the nest showed food preferences similar to those of the adults.

Establishment of isolated farms in otherwise primitive areas invites the possibility of damage by pigeons as well as other wild creatures and should be discouraged. Farmers now located in areas where pigeons cause damage to crops can adequately protect their crops by diligently following procedures recommended. 
As the reproductive potential of the bandtail is low (in some parts of its range only one clutch is laid and this normally is composed of one egg), it cannot withstand severe drains on its numbers. For that reason demands for more liberalized shooting should be carefully scrutinized.

Management of the bandtail must be built on the premise of safeguarding the species from threatened decimation, yet there should be recognition of the fact that severe crop damage may be inflicted and effective remedial measures must be available.

Looking toward a long-time program of management, the basic population must be carefully watched and undue decimation through hunting prevented. Those accepted principles of forestry that will prevent forest destruction, and that will preserve the oaks and pines, and the wild fruits and berries that supplement mast as a food, will be advantageous to the band-tailed pigeon.

\section{BIBLIOGRAPHY}

Abbott, Ctinton Githeit,

1927. Notes on the nesting of the band-tailed pigeon. Condor 29: 121-123.

ALCORN, J. RAY.

1941. New and additional Nevada bird records. Condor 43: 118-119.

Bailfy, Florence merriam.

1902. Handbook of birds of the western United States, 511 pp., illus. Boston.

1923. Birds recorded from the Santa Rita Mountains in southern Arizona. Pacific Coast Avifauna 15,60 pp., illus.

1928. Birds of New Mexico. 807 pp., illus. Santa Fe, N. Mex.

Barings, E. $P$.

1916. Band-tailed pigeons alleged destruction of grain. Calif. Fish and Game 2: 212.

BarToL, MaRY.

1940. High, wild, and handsome. Ontdoor Life 85 (4) : 26-27, 107-10:3,

Broping, Lymax.

1879. A partial list of the birds of central California. U. S. Nat. Mus. Proc. 1: 388-499.

1890. Land birds of the Pacific district. Calif. Acad. Stei. Occas. Papers 2, 274 pp. San Francisco.

Bendire, Charles Fmil.

1892. Life histories of North American birds with special reference to their breeding habits and eggs. U. \$. Nat, Mus. Spec. Bull. 1, 446 pp., illus.

Bengon, Seth Bhrthait.

1935. Blological reconnaissance, Navajo Mountains, Utah. Univ. Calif. Pub. Zool, 40 (4): 445 pp.

Bent, arthur Clevhiand.

1932. Life histories of North American gallinaceous birds. U. S. Nat. Mus. Bull. 162, 490 pp., illus.

Bergtold, William Harky.

1912. October birds of the Gila River, New Mexico. Auk 29: 331.

1928. A guide to the birds of Colorado. 207 pp., illus. Denver.

Brooks, allan Crrm, and Swarth, Harry Scheiwaldt.

1925. A distributional list of the birds of British Columbia. Pacific Coast Avifauna 17, 158 pp., illus.

BURTCH, JEWIs.

1930. Wild pigeons-Kern County, California. Calif. Dept. Agr. Monthly Bull. $19(5)$ : 375-376. 
Chambirs, Wiflite LleE.

1912. Who will save the band-talled pigeon? Condor 14: 108.

Cooper, James Graham.

1880 . On the migration and nesting habits of West Coast birds.

U. S. Nat. Mus, Proc. 2: 241-251.

Cottam, Clailence.

1941. Indigo bunting and band-tailed pigeon in Utah. Conclor 48: 122.

Davis, John M.

1938. Nesting dates in Humboldt Bay region. Condor 40: 182-183

DAWSON, WILHAM LEON.

1923. The birds of C'nlifornia. Student's ed. 3 vols., 2.121 pp. illus. Los Angeles.

Dean, W. F.

1904. A few notes on bird life at Three Rivers, Tulare County, California. Condor $6: 110-111$.

I)ERRY, WILLIAMY $\mathrm{F}$.

1920. Band-tailed pigeon nests in Sequoia National Forest. Calif. Fish and Game 6: 182 .

Giermann, Rarton Warien.

1886. A list of the birds observed in Ventura County, California. Auk 3: 86-94.

Fisher, Albert Kfnimick.

1893. Birds of the Death Valley experition. North Amer. Fauna 7, $158 \mathrm{pp}$.

Fowler, Freperick Hait,

1903. Stray notes from southern Arizona. Condor 5: 68, 71.

Gabrighson, Ira Noel, and Jewett, Staniny golion.

1940. Birds of Oregon. 650 pp., illus. Portland, Oreg.

Gruman, marshali, French.

1903. More alont the bund-tailed pigeon (Columba fasciata). Condor 5: 134-135.

Grinnehi, Joshep.

1898. Birls of the Pacific slope of Los Angeles County. I'asadena Acad. Sci. Pub, 2, 52 pp.

1905. Summer birds of Mount Pinos, Callfornia. Auk 22: 378-391.

1913. The outlook on conserving the band-tailed pigeon as a game bird of California. Condor 15:25-40.

1915. A distributional list of the birds of California. Pacific Coast Avifauna 11, 217 pp.

1928. September nesting of the band-titiled pigeon. Condor $30: 126$.

- Mryant, Iharold Chitd : and Storer, Tracy Irwin.

1918. The game birds of California. $642 \mathrm{pp}$. Berkeley.

- Dixon, Joseph Scattrkoon: and Lingdit., Jean MYron.

1930 . Vertebrate natural history of a section of northern Californla throngh the Lassen l'eak region. Univ. Calif. Pub. Zool. 35. 594 pp. Allus. Berkeley.

and Stoner. Tiser IRWrN.

1924. Animal life in the Yosemite . . 741 pp., 1llus. Berkeley.

and Wythe. Margaker Wil.helmin.

1927. Directory to the bird life of the San Franctsco Bay region. Pacific Coast Avifauna 18, 160 pp., illus,

Hagenstein, WaLter M.

1936. Late nesting of the band-tailed pigeon. Murrelet 17: 21-22.

HeNSHA H, HFNY WitherREF.

1886. Birds of the Upper Pecos River, New Mexico. Auk 3: 80.

Hi'eY, LawReNCF: MaliKhaM.

1913. With the band-tailed pigeon in San Diego County. Condor 15: 151-153. 
HUNTER, JOSHPH SI.AYTHN.

1936. Kill of game in State is compiled (1934-35 fiscal year). Calif. Conserv. 1 ( 8 ): 3.

1937. Kill of game in State is compiled (1935-36 fiscal year). Calif. Conserv. 2 (8): 20.

JewetT, Staniey Golidon.

1941. Late nesting of the band-tailed pigeon. Condor 43: 78 .

-... and Gabrielson, Ira Nofi..

1929. Birds of the I'ortland, Oregon, area. I'acific ('oast Avifauna 19, 55 pp., Illus.

Johnson, O. B.

1880. List of the birds of the Willamette Valley, Oregon. Amer. Nat. July, pp. $638-639$.

Kr.oppenbulo, H. A.

1922. Band-talled pigeons abundant in Plumas National Forest. Calif. Fish and Game 8: 57.

KOBBE, William HoFfMaN,

1900. The birds of Cape Disappointment, Washington. Auk 17: 349-358

Ligon, JAMFs SToKei.y.

1927. Wildife of New Mexico: its conservation and management. 212 pp., Illus. Santa Fe.

MCATEe, Wardo LEN.

1932. The need for studies in bird control in California. Calif.

Dept. Agr. Monthly liull. (4-5-6) : 269-286.

Mclean, Donald Dudiex.

1925. A western goshawk scatters Yosemite's band-tailed pigeon colony. Yosemite Nature Notes 4: 103.

Michaer, Charles Wilson.

1928. Nesting time of band-tailed pigeons in Yosemite Valley. Condor $30: 127$.

Mitiler, Ronerte Cunningham ; Lumtex, Fitswonth L.; and Hall. F. S. 1935. Birds of the Nan Juan Islands, Washington. Murrelet 16 (3): 51-65.

MoRan, Nathan.

1919. Nesting of the band-talled pigeon. Calif. Flsh and Game 5: 160.

Munro, James AIExander.

1922. The band-tailed pigeon in British Columbia. Canadian Field-Nat. 36: $1-4$.

1924. Miscellaneous bird notes from Vancouver Island, 1923. Canadian Field-Nat. 38: 149-150.

Nick, Margaret Morsf, and Nice. Leonard Blaine.

1924. The birds of Oklahoma. Univ. Oklahoma Bull., new series 20 , Univ. studies 286, 122 pp., illus, May 15. Norman, Okla.

Nimprach, Robert J., and Rockwell, Robert B.

1929. Birds of Denver and Mountain Parks. Colo. Mus. Nat. Hist. Pop. Ser. 5, p. 89.

NoACK, H. R.

1916. Band-talled pigeons bred in captivity. Calif. Figh and Game 2: 212.

ObFrholser, HaRry ChukCh.

1902. Some notes from west Texas. Auk 19: 300.

PEARSE, TheED.

1935. Display of the band-talled pigeon. Murrelet 16 (3): 71-72.

1940. Precarious status of the band-tailed pigeon on Vancouver Island. Murrelet 21: 10-11.

Presnati, Clifford Chartes.

1935. Birds of Zion National Park. Utah Acad. Sci. 12: 201.

RIDGW AY, ROBERT.

1916. The birds of North and Middle America, U. S. Nat. Mus. Bull. 50 , part 7 , pp. $288-291$. 
SHUFELDT, RoBeRT WiI.soN.

1912. The band-tailed pigeon in North Dakota. Ank 29: 539-540.

STILL.HUNTEk.

1907. South coast shooting. IX: The band-tailed pigeon. Western Field 11: 200-202.

Stillman, A. E.

1928. Nesting of the band-tailed pigeon. Amer. Forests. May, pp. $267-268$.

SWARTh, HarbY ScheLWALDT.

1904. Birds of the Huachuca Mountains, Arizona. Pacific Coast Avifauna $4,70 \mathrm{pp}$.

1914. A distributional list of the birds of Arizona. Pacific Coast Avtfauna 10, $133 \mathrm{pp}$.

Taverner, Percy algernon.

1926. Birds of western Canada. Canada Dept. Mines, Victoria Memorial Mus. Bull. 41 (Biol. Ser. 10), 380 pp., illus. Ottawa.

1934. Birds of Canada. Canada Dept. Mines, Nat. Mus. Bull. 72 (Biol. Ser. 19), 445 pp., illus. Ottawa.

Taylor, Walter Penn.

1924. The present status of the band-tailed pigeon on the Pacific coast. Calif. Fish and Game 10: 1-9.

Van Denburgh, John.

1899. Notes on some birds of Santa Clara County, California. Amer. Philos. Soc. Proc, 38: 157-180.

VAN Rossem, ADRIAN JosePH.

1914. Notes from the San Bernardino Mountains. Condor 16: 145-146.

Van Tyne, Jocelyn, and Sutton, George Misch.

1937. The birds of Brewster County, Texas. Univ. Michigan Mus. Zool. Misc. Pub. 37, illus.

Vorhies, Charles Taylor.

1928. Band-tailed pigeons nesting in Arizona in September. Condor 30: 253.

Wales, Joseph Howe.

1926. The coo of the band-talled pigeon. Condor 28: 42 .

W HEELOCK, IRENe GRosvenor.

1904. Birds of California. 578 pp. illus. Chicago.

WiLlakd, Franites CotTt.e.

1913. Some late nesting notes from the Huachuca Mountains, Arizona. Condor 15: 41.

1916. Nesting of the band-tailed pigeon in southern Arizona. Condor $18: 110-112$.

WILLET, GEORGE.

1933. A revised list of the birds of southwestern California. Pacific Coast Avifauna 21, 204 pp. 


\section{INDEX}

Abundance, early day, 2. present status, 33 .

Acetylene flash gun, 48, 49.

Agricultural relationships, $3, \mathbf{3 7 - 4 5}$.

Behavior, 6.

calls, 5.

courtship, 5 .

flight, 6 .

flocking, 6 .

perching, 6 .

Berries as food, 38-43, 51-53, 55-63.

Calls, 5.

Care of young, 13-15.

Columba fasciata fasciata, 1.

Communal nesting, 11, 12.

Control of Damage, 45-50.

by acetylene flash gun, $48,49$.

by flash bombs, 49 .

by paper streamers, 48 .

by shooting, 45-47.

by signal flares, 49 .

by tree covers, 48, 49.

permits for, $3,49,50$.

proper timing, 47.

Cooper's hawk, 17.

Courtship, 5 .

Decoys, use of, 33.

Depredations, cherries, 3, 38-43. grains, 38, 43-45.

grapes, 42.

prunes, 42.

walnuts, 45 .

Description, adult, 4. nestling, 5.

Development, feather, 15.

Disease, 17.

Distribution, general, 17.

map, 18.

summer, 18.

winter, 24 .

Eggs, 12.

description, 12.

discovery, 2.

number, 6, 12.

size, 12.

Enemies, 17.

Falcon, prairie, 17.

fasciata fasciata, Columba, 1.

Feather development, 15.

Feeding mannerisins, $6 \mathrm{~s}$.

Flash bombs, 49.

Flight, 6.

Flocking, 6.

Food, autumn, 65. berries, $38-43,51-53,55-68$.

general, 51-71.

grains, $43-45,51-53,55-58,03-68$. insect, 53,63 .

mast, 37, 38-43, 51-53, 55-59, 63-63. quantity taken, 68,69 .

seasonal preferences, 63 .

spring, 64.

summer, 64 .

winter, 63.

Grains as food, 43-45, 51-53, 55-58, 63-68.

Gravel, use of, 68.

Growth of young, 13-15.

Hawk, Cooper's, 17.

goshawk, 17.

prairie falcon, 17.

sharp-shinned, 17.

Hunting, 2, 30, 31, 32, 33.

bag limit, $\mathbf{3}$.

effects of, 2, 31, 32. 33 .

practices, 2, 3, 30-i3.

season trends, 34, 36 .

seasons, 3,30 .

wastage in, 31-33.

Incubation period, 12.

Kill, records of, $31-33$.

Location of nests, 9 .

Management, 36 .

fire prevention, 37.

increasing food supply, 37, 49.

reforestation, 37.

stringent protection, 37.

wilderness maintenance, 37 .

Mast as food, $37-43,51-53,55-58$, 63-68.

Measurements, 4, 5.

Migration, autumn, 27. routes of, 29. spring, 26.

Molts, 5.

Nesting, 6-12. seasons, 6-7.

Nest location, 9 . structure, 9-10.

Paper streamers, 48.

Parasites, internal, 17.

Perching, 6.

Permits for control, 3, 49, 50.

Pigeon, band-tailed, 1. discovery of, 2.

blue, 1 .

blue rock, 1 .

history, 2.

milk, 13, 16.

wild, 1.

Plumages, adult, 4. nestling, 5 .

Prairie falcon, 17.

Predators, 17.

Protection, $3,30,36$.

Quantity of food taken, 68, 69.

Range, summer, 18.

winter, 24.

Records, banding, 29. 
76 NORTH AMERICAN FAUNA 58, FISH AND WILDILIFE SEIRICE

Routes of migration, 29.

Salt, use of, i4.

Season of nesting. $\div-\bar{t}$.

Sharp-shinfed hawk. 17.

Shooting. control by, 47-47.

Signal Hares, 49.

Squirrel, gray, 17.

Streamers, paper, 48.

Structure of nests, 9, 10.

True covers, 48. 49.

Ise of rlecoys, :33. gravel, 68 .

salt, 54.

Valne as game, 29.

Weights, 4, 15.

Western goshawk, 17.

Young, 13-16. activity of. 15 . brooding of, 15 . care of. 13-16.

feather growth, 15.

food of, 13.

growth of, 13-16.

we'ght of, $4,15$.

U. S. GOVERNMENT PRINTING OFFICE: 1947-695766 